Universidade de Brasília

Instituto de Geociências

\title{
GEOLOGIA E PETROLOGIA DOS BASALTOS DAS FORMAÇÕES MOSQUITO E SARDINHA, BACIA DO PARNAÍBA
}

\author{
Dissertação de Mestrado \\ № 395
}

Alisson Lopes Oliveira

Brasília - DF

Março de 2017 
Universidade de Brasília

Instituto de Geociências

\title{
GEOLOGIA E PETROLOGIA DOS BASALTOS DAS FORMAÇÕES MOSQUITO E SARDINHA, BACIA DO PARNAÍBA
}

\author{
Alisson Lopes Oliveira
}

Orientador: Prof. Dr. Márcio Martins Pimentel

Co-Orientador: Prof. Dr. Reinhardt Adolfo Fuck

Examinadores: Prof. Dr. Elton Luiz Dantas (UnB)

Dra. Joseneusa Brilhante Rodrigues (CPRM) 


\section{SUMÁRIO}

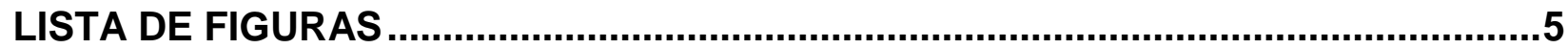

LISTA DE TABELAS

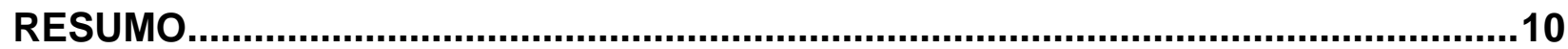

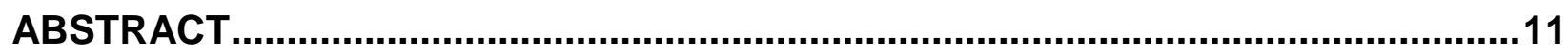

1. APRESENTAÇÃO

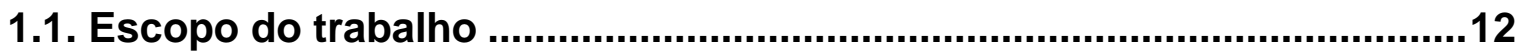

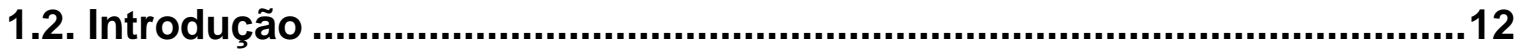

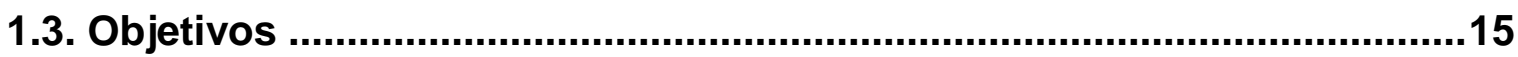

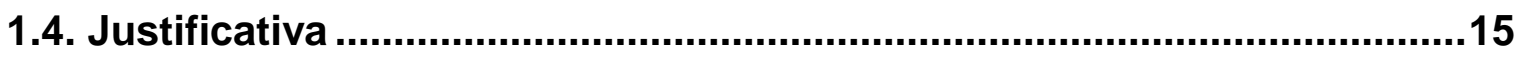

2. PETROLOGY OF JURASSIC AND CRETACEOUS BASALTIC FORMATIONS FROM THE PARNAÍBA BASIN, NE BRAZIL: CORRELATIONS AND LIP ASSOCIATIONS.17

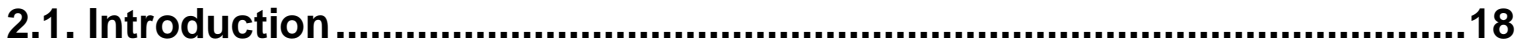

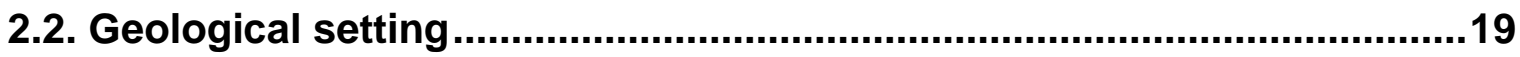

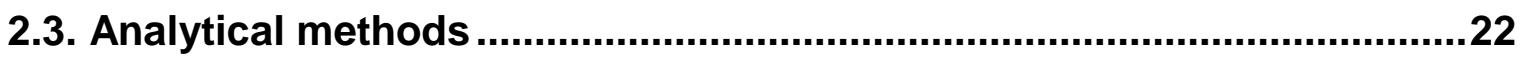

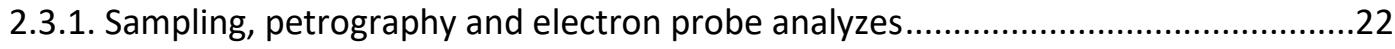

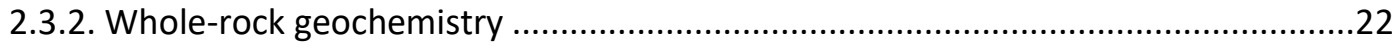

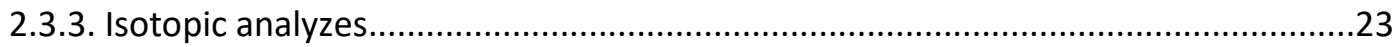

2.4. Magmatism of the Parnaíba Basin...................................................24

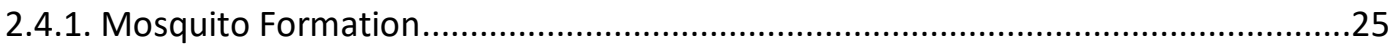

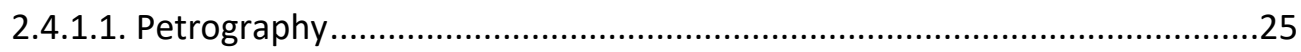

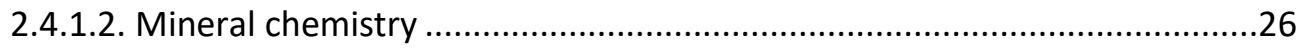

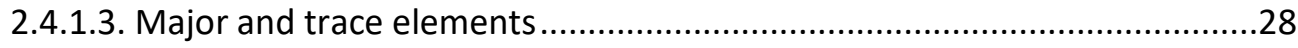

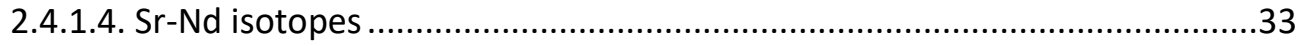

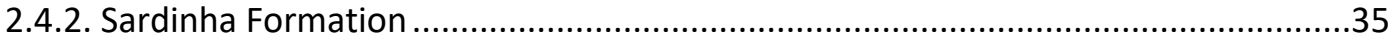

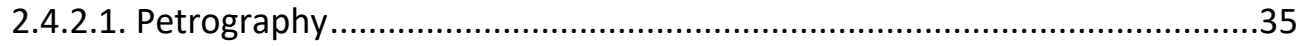

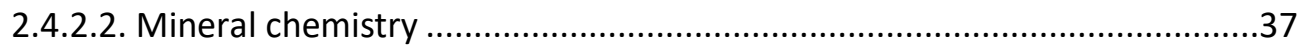

2.4.2.3. Major and trace elements ......................................................................38

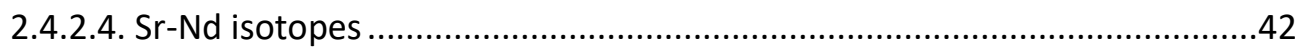

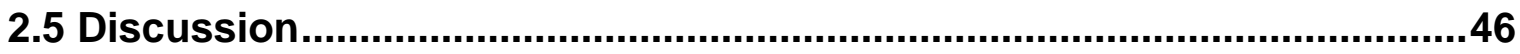

2.5.1 Comparison between the Mosquito and Sardinha formations...............................46 
2.5.2. Mosquito and Sardinha basalts and their correlation with CAMP, PEMP and EQA events

2.5.3. Geochemical modelling

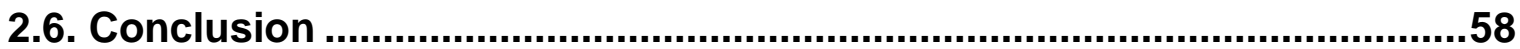

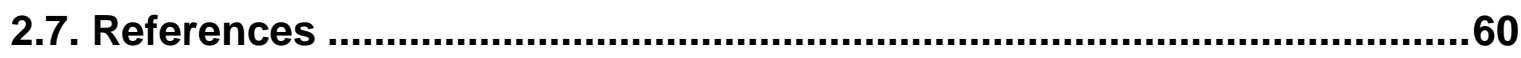

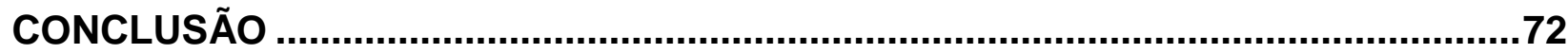

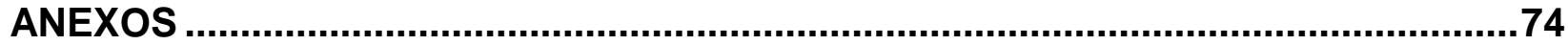

4.1. Química mineral em olivina ....................................................................74

4.2. Química mineral em clinopiroxênio (augita) ...........................................75

4.3. Química mineral em clinopiroxênio (pigeonite) ........................................77

4.4. Química mineral em plagioclásio .............................................................78

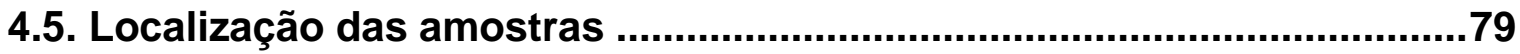




\section{LISTA DE FIGURAS}

Figure 1 - a) Schematic map showing neoproterozoic Brazilian cratons, basins and orogenic belts (modified after Sadowski and Campanha, 2004; Zalán, 2004). b) Map and stratigraphy of the Parnaíba basin displaying sample location (modified after Angelim et al., 2004; Bahia et al., 2004; Faraco et al., 2004a, 2004b; Kosin et al., 2004; Vasconcelos et al., 2004a, 2004b; 2004c; 2004d). Basement rocks are undifferentiated but mainly composed of neoproterozoic orogenic belts (Borborema Province and Tocantins Province at the western and eastern margin, respectively). 21

Figure 2 - a) Total alkali vs silica diagram showing the alkaline and sub-alkaline fields (after Irvine and Baragar, 1971; Le Bas et al., 1986); b) AFM (alkalis, iron and magnesium) ternary diagram, discriminating tholeiitic and calc-alkaline series (Irvine and Baragar, 1971).

Figure 3 - Overall aspects of the Mosquito Formation. a) lava flow outcrop; b) typical amygdaloidal basalt; c) low-Ti basalt with highlighted mineral assemblage and calcite amygdule;. d) low-Ti basalt with similar mineral assemblage shown on figure $c$ but with unfilled vesicle; note that on both figure $c$ and $d$, mineral sizes do not vary much and are mostly smaller than $200 \square \mathrm{m}$ across. e) high-Ti basalt with zoned porphyritic plagioclase; f) high-Ti basalt with ophitic texture displaying a larger clinopyroxene crystal with plagioclase inclusions. Micro petrographic photos were taken with parallel polarizers. $\mathrm{PI}=$ plagioclase, $\mathrm{cpx}=$ clinopyroxene, $\mathrm{mt}=$ magnetite $(\mathrm{Fe}-\mathrm{Ti}$ oxide $), \mathrm{gl}=$ volcanic glass, ves $=$ vesicle, $\mathrm{cb}$ $=$ carbonate (calcite).

Figure 4 - Mg\# vs $\mathrm{TiO}_{2} \%$ low-Ti basalts of the Mosquito Formation showing negative trends both on augite and pigeonite crystals. $\mathrm{TiO}_{2}$ oxide saturation was not obtained on these early stages of crystal development. Dotted and dashed lines represents augite and pigeonite linear trends, respectively. .28 
Figure 5 - Major element vs silica diagrams for the Mosquito Formation tholeiites. The two compositional groups of high and low- $\mathrm{Ti}$ illustrate are clearly distinct with respect to their major element compositions.

Figure 6 - Multi-element diagrams for the Mosquito Formation samples. Primitive mantle normalizing values, OIB and MORB compositions are after Sun and McDonough (1989), chondrite normalizing values are after McDonough and Sun (1995). a) Primitive mantle normalized diagram for low-Ti Mosquito Formation displays a broad positive $\mathrm{K}$ anomaly, with the characteristic CAMP Nb-Ta negative anomaly and negative $\mathrm{P}$ anomaly (with the exception of sample BP-35). b) Primitive mantle normalized diagram for high-Ti Mosquito basalts showing scattered LILE values with homogeneous HFSE, Nb-Ta and P (except samples BP-128) negative anomalies. c) and d) Chondrite normalized diagram for the Mosquito Formation rocks (symbols as in $a$ and $b$ ). 30

Figure 7 - Mosquito Formation initial ${ }^{87} \mathrm{Sr} /{ }^{86} \mathrm{Sr}-{ }^{143} \mathrm{Nd} /{ }^{144} \mathrm{Nd}$ isotopic ratios. 33

Figure 8 - General aspects of the Sardinha Formation. a) Diabase dyke hand sample of the Sardinha Formation; b) Typical alkali-basalt hand sample of the Sardinha Formation, showing an aggregate of olivine crystals; c) Group i) Sardinha basalt (DCO-46) with highlighted mineral assemblage, note zoned clinopyroxene and late stage quartz/Kfeldspar intergrowth (high-Ti Sardinha Formation sample). d) Group (i) Sardinha basalt with similar mineral assemblage shown on figure $c$ showing less alteration, greater glass occurrence and sub-ophitic texture (low-Ti Sardinha Formation sample). e) Group (ii) Sardinha basalt, showing mineral assemblage with zoned clinopyroxene crystal and lack of glass material (high-Ti Sardinha Formation sample). f) Group (iii) olivine basalt (low- Ti Sardinha Formation sample). g) Group (iv) Sardinha Formation diabase/gabbro with well developed euhedral porphyritic clinopyroxene crystal encompassing olivine and plagioclase crystals. h) Olivine alkali-basalt, euhedral olivine and diopside crystals immersed in fine grained aphanitic matrix, note olivine with clinopyroxene rim. Micro petrographic photos were taken with crossed polarizers. $\mathrm{Ol}=$ olivine, $\mathrm{pl}=$ plagioclase, $\mathrm{cpx}$ 
$=$ clinopyroxene, $\mathrm{mt}=$ magnetite $(\mathrm{Fe}-\mathrm{Ti}$ oxide $), \mathrm{gl}=$ volcanic glass, $\mathrm{qtz}=$ quartz, $\mathrm{K}-\mathrm{f}=\mathrm{K}-$ feldspar.

Figure 9 - Major elements versus silica variation diagrams for Sardinha Formation rocks. High-Ti, low-Ti and Alkali-basalt groups, display small variation within their respective data clusters. 44

Figure 10 - Multi-element diagrams for the Sardinha Formation basalts (see text for information about highlighted samples). Primitive mantle normalizing values, OIB and MORB compositions after Sun and McDonough (1989), chondritic normalizing values after McDonough and Sun (1995); a) Primitive mantle normalized diagram for low-Ti and alkali-basalt of the Sardinha Formation. b) Primitive mantle normalized diagram for highTi Sardinha basalts. c) Chondrite normalized diagram for the low-Ti and alkali-basalts. d) Chondrite normalized diagram for the high-Ti Sardinha Formation rocks. .45

Figure 11 - Sardinha Formation initial ${ }^{87} \mathrm{Sr} /{ }^{86} \mathrm{Sr}-{ }^{143} \mathrm{Nd} /{ }^{144} \mathrm{Nd}$ isotopic ratios diagram. ....46

Figure 12 - Comparison plots between the Mosquito and Sardinha Formations, see text for detailed discussion. .49

Figure 13 - Mosquito Formation and CAMP analyzes for major and trace elements and $\mathrm{Nd}-\mathrm{Sr}$ isotope data. The high- and low-Ti compositions are similar to those of the African (Bensalah et al., 2011; Bertrand et al., 1982; Chabou et al., 2010), European (Callegaro et al., 2013, 2014; Cebriá et al., 2003; Cirrincione et al., 2014; Martins et al., 2008), North (Marzoli et al., 2011) and South American (Deckart et al., 2005; Merle et al., 2011) CAMP event. MORB, OIB, BSE, EMI and EMII isotopic compositions are those suggested by Zindler and Hart (1986). .51

Figure 14 - Comparison between the Sardinha Formation, Fernando de Noronha basalts, PEMP and EQA magmatic events. Fernando de Noronha (FN) compositions from Gerlach 
et al (1987). PEMP compositions from Cordani et al (1988), Ewart et al (2004), Garland et al. (1995, 1996), Gibson et al (1999), Hawkesworth et al. (1992), lacumin et al (1991), Kirstein et al (2000), Mantovani and Hawkesworth (1988), Marques et al (1989, 1999), Peate and Hawkesworth (1996), Peate et al (1990, 1992, 1996, 1999), Petrini et al (1987), Rämö et al (2016), Rocha-Junior et al (2012, 2013), Simon et al (1999a, 1999b). EQA composition from Hollanda et al (2006). Ponta Grossa (PG) dykes from Piccirillo et al (1990). HIMU, MORB, OIB, BSE, EMI and EMII isotopic compositions from Zindler and Hart (1986). Green, purple, red, orange and yellow fields representative of Urubici, Pitanga, Paranapanema, Esmeralda and Gramado PEMP-basalt types of the Paraná Basin. In figure (d) the gray field include all PEMP magma types of the Paraná Basin. .54

Figure 15 - Assimilation and Fractional Crystallization model for initial isotopic ${ }^{87} \mathrm{Sr} /{ }^{86} \mathrm{Sr}$ vs ${ }^{143} \mathrm{Nd} /{ }^{144} \mathrm{Nd}$ compositions of the Mosquito (a) and Sardinha (b) Formations using DMM and HIMU mantle end-members as primary sources for the basalts. Solid and dashed lines mark DMM (Workman and Hart, 2005) and HIMU (Hanyu et al., 2011) end-members as primary sources, respectively. Colors indicate contaminants or assimilants; blue for EMII(Sa) (Samoa Islands; Jackson et al., 2007), black for SJE (K-diorites and granites of the Seridó Domain; Hollanda et al., 2003), red for SCLM (average lamproite composition; Rock, 1991). Cross and $X$ marks indicate Fractional Crystallization percentage from the source to assimilants by additional $10 \%$ for each marker from DMM and HIMU, respectively. The gray field indicates a ternary plot with HIMU, EMI (Zindler and Hart, 1986) and EMII(B) (Ben Othman et al., 1989) as mantle end-members, tick marks with numbers indicate the mixing proportions between the isotopic compositions for each endmember (black star). EMII composition from Zindler and Hart (1986). SJS (tonalities of the Seridó Domain) isotopic composition from Hollanda et al (2003). Fields assigned by

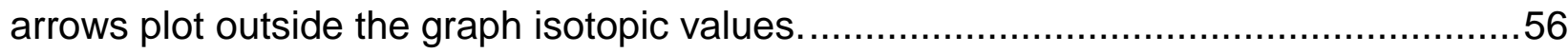




\section{LISTA DE TABELAS}

Table 1 - Compositions of whole-rock samples from the Mosquito Formation.

Table 2 - Isotopic compositions of Mosquito Formation basalts

Table 3 - Compositions of whole-rock samples from the Sardinha Formation................39

Table 4 - Isotopic composition of Sardinha Formation basalts. .43 


\section{RESUMO}

A Formação Mosquito (FM) e Formação Sardinha (FS) representam ocorrências basálticas na Bacia do Parnaíba, no Nordeste do Brasil, relacionadas à abertura do Oceano Atlântico no período Jurássico/Triássico e Cretáceo, respectivamente. A FM e FS são comumente associadas às províncias de Derrames Basálticos Continentais, como a Província Magmática do Atlântico Central e a Província Magmática Paraná-Etendeka. A FM compreende fluxos toleíticos de alto- e baixo-Ti, formados por basaltos de dois piroxênios, com características petrogenéticas relacionadas aos reservatórios do manto tipo HIMU e EM, respectivamente. As composições isotópicas radiogênicas de $\mathrm{Sr}$ (0.70296-0.70841) e não-radiogênicas a ligeiramente radiogênicas de $\mathrm{Nd}$ (0.5121840.512677), associadas ao enriquecimento em elementos large-ion lithophile (LIL) e highfield strenght (HFS) em relação aos valores do manto primitivo compreendem aspectos cruciais da FM.

A FS é composta de diques toleíticos de alto- e baixo-Ti, juntamente com derrames basálticos e diques alcalinos em menor quantidade. Os basaltos e diabásios da SF são compostos por piroxênio de composições augíticas ou diopsídicas, associado a plagioclásio e, ocasionalmente, olivina. Eles possuem características geoquímicas e isotópicas associadas ao manto do tipo HIMU e EM. A maioria das composições de basaltos alcalinos, de alto- e baixo-Ti da SF varia entre 0.7047-0.7070 de Sr inicial e 0.5123-0.5126 de Nd inicial com enriquecimento em elementos LIL e HFS em relação aos valores do manto primitivo.

Embora exista semelhanças entre a FM e FS, estas podem ser diferenciadas levando em consideração composições de elementos traço tais como $\mathrm{Nb}, \mathrm{Ta}$, $\mathrm{Pb}$ e razões $\mathrm{La} / \mathrm{Yb}$. Assim, características petrográficas e de elementos traço produzem particularidades individuais intrínsecas a cada formação basáltica que permitem a caracterização destas na Bacia do Parnaíba. A fonte do magmatismo da Bacia do Parnaíba pode estar relacionada a componentes do manto enriquecido desencadeados por interações com plumas mantélicas ou fusão litosférica devido a incrementos de temperatura abaixo do supercontinente Pangea. 


\section{ABSTRACT}

The Mosquito Formation (MF) and Sardinha Formation (SF) are basaltic occurrences in the Parnaíba Basin, Northeastern Brazil, related to the opening of the Atlantic Ocean at Jurassic/Triassic and Cretaceous age, respectively. The MF and SF are commonly associated with Continental Flood Basalt provinces such as the Central Atlantic Magmatic Province and the Paraná-Etendeka Magmatic Province. The MF comprises tholeiitic flows with high- and low-Ti nature, formed by two-pyroxene basalts, with petrogenetic characteristics related to HIMU and EM-type mantle reservoirs, respectively. Radiogenic Sr (0.70296-0.70841) and non-radiogenic to slightly radiogenic $\mathrm{Nd}$ (0.5121840.512677 ) isotopic compositions, associated with enrichment in large-ion lithophile (LIL) and high-field strength (HFS) elements relative to primitive mantle values comprises crucial aspects of the MF.

The SF is composed of high- and low-Ti tholeiitic dykes together with alkaline basaltic flows and dykes in lesser amount. The SF basalts and diabases are composed by augitic or diopsidic pyroxene associated to plagioclase and occasionally olivine. They have geochemical and isotopic features associated to HIMU and EM-type mantle endmembers. Most alkaline, high- and low-Ti SF basalts compositions range between 0.7047-0.7070 of initial Sr and 0.5123-0.5126 of initial Nd with enrichment in LIL and HFS elements relative to primitive mantle values.

Although the MF and SF share similarities, they can be differentiated taking into consideration trace element compositions such as $\mathrm{Nb}, \mathrm{Ta}, \mathrm{Pb}$ and $\mathrm{La} / \mathrm{Yb}$ ratios. Thus, petrographic characteristics and trace elements contents yield individual features intrinsic to each basaltic formation that allows a characterization in the Parnaíba Basin. The source for the Parnaíba Basin magmatism can be related to enriched mantle components triggered by mantellic plume interactions or lithospheric melting due to temperature increases bellow the Pangea supercontinent. 


\section{APRESENTAÇÃO}

\subsection{Escopo do trabalho}

Esta dissertação de mestrado está estruturada em quatro partes. A primeira parte trata da apresentação do tema, com objetivos, justificativas e introdução ao estudo. A segunda parte, totalmente formulada em inglês, compõe a pesquisa em si, na forma de artigo científico a ser submetido para publicação em periódico científico internacional. A terceira parte apresenta a síntese de resultados e conclusões da pesquisa, inclusive as já apresentadas com detalhe no artigo. Finalmente, a quarta parte (anexos) expõe de maneira simplificada as análises de química mineral, com as composições representativas de minerais que fizeram parte do trabalho (clinopiroxênios, plagioclásio e olivina) bem como a localização das amostras.

\subsection{Introdução}

Este trabalho faz parte de projeto conjunto entre universidades brasileiras, universidades do exterior (Reino Unido) e a BP P.L.C. (British Petroleum) na Bacia do Parnaíba. O projeto contou com estudos geofísicos, geológicos e, especificamente nesta dissertação, a caracterização geoquímica e petrológica de formações basálticas da bacia.

As rochas vulcânicas máficas oriundas de derrames basálticos, diques e soleiras na Bacia do Parnaíba foram alvo de estudos relacionados à sua natureza geoquímica, isotópica e petrológica desde o início da década de 1990 (Góes e Feijó, 1994). A Bacia do Parnaíba possui sua história evolutiva associada ao fim da Orogenia Brasiliana e seu embasamento é composto por rochas metamórficas provenientes de processos tectonomagmáticos do Arqueano até o Cambro-Ordoviciano (Daly et al., 2014; da Silva et al., 2003; Góes e Feijó, 1994; Vaz et al., 2007).

As rochas sedimentares da bacia (predominantemente siliciclásticas) foram caracterizadas por Góes e Feijó (1994) e divididas em quatro grupos e uma sequência (grupos Serra Grande, Canindé, Balsas e Mearim e sequência Grajaú-Codó-Itapecuru). Posteriormente, Vaz et al. (2007) reinterpretaram as rochas sedimentares da bacia, retirando as rochas do grupo Mearim (formações Pastos Bons e Corda), atribuindo 
apenas a denominação de Formação a ambas. Desta forma, a classificação litoestratigráfica da bacia é definida por três grupos e cinco formações sedimentares, além de duas formações vulcânicas: i) Grupo Serra Grande; ii) Grupo Canindé; iii) Grupo Balsas, formações Pastos Bons, Corda, Grajaú, Codó e Itapecuru e as formações vulcânicas Mosquito e Sardinha. A Formação Mosquito (FM) de idade juro-triássica e a Formação Sardinha (FS) de idade cretácea (Góes e Feijó, 1994; Vaz et al., 2007) constituem as formações vulcânicas da bacia.

Por suas características, as formações basálticas da Bacia do Parnaíba foram relacionadas a derrames de basaltos continentais, ou, pela denominação em inglês, Continental Flood Basalts (CFBs). Em geral as CFBs possuem características de magmas toleíticos e são classificadas em dois grupos, um associado a ambiente de pluma magmática e outro a fusão parcial de manto litosférico subcontinental (Marsh, 1987; Puffer, 2001). A maioria das províncias magmáticas do planeta, como apresentado por Puffer (2001), quando classificadas levando em consideração a composição de elementos traço e elementos terras raras, plotam próximo à composição de basaltos de ilha oceânica, sendo considerados como provenientes de ambiente de pluma mantélica. No entanto, essa gênese não é categórica, já que as províncias caracterizadas como provenientes de porções do manto litosférico subcontinental enriquecido possuem assinaturas geoquímicas semelhantes a rochas de arco magmático (Puffer, 2001).

No caso das formações magmáticas da Bacia do Parnaíba, a FM e FS foram correlacionadas principalmente às rochas originadas a partir do rifteamento do supercontinente Pangea e abertura do Oceano Atlântico. Thomaz Filho et al. (2008) associam ainda as ocorrências magmáticas da bacia com o gradiente geotérmico que pode ter gerado hidrocarbonetos nas sequências sedimentares, tornando regiões de ocorrência dessas rochas como possíveis prospectos para ocorrências de gás e óleo na Bacia do Parnaíba. Baseando-se em idades isotópicas (K-Ar ou Ar-Ar), a FM foi determinada como pertencente à Província Magmática do Atlântico Central (ou Central Atlantic Magmatic Province - CAMP, como é mais conhecida), enquanto a FS foi associada à Província Magmática Paraná-Etendeka (ou Paraná-Etendeka Magmatic Province - PEMP) (Baksi et al., 1997; Góes e Feijó, 1994; Mizusaki et al., 2002). 
A CAMP é considerada uma das maiores extensões de derrames basálticos do mundo (Coltice et al., 2007; Marzoli et al., 1999). Estende-se por quatro massas continentais ao redor do Oceano Atlântico e perfaz uma área total de aproximadamente 7 milhões de quilômetros quadrados. O pico principal de atividade magmática ocorreu por volta de $201 \mathrm{Ma}$, próximo ao limite Triássico-Jurássico marcado por extinção em massa (Marzoli et al., 1999). Rochas pertencentes ao evento CAMP são encontradas nas regiões leste da América do Norte, nordeste da América do Sul, noroeste da África e pequenas porções no sudoeste da Europa (Marzoli et al., 1999). São constituídas principalmente por diques, sills e derrames toleíticos em áreas cratônicas arqueanas a proterozóicas e bacias paleozóicas. No Brasil, por exemplo, o maior volume desse magmatismo ocorre nas bacias paleozóicas do Amazonas e Parnaíba ou como diques nos terrenos neoproterozóicos da Província Borborema (Merle et al., 2011; Mizusaki et al., 2002; Thomaz Filho et al., 2008).

A mais conhecida CFB relacionada ao rifteamento do Supercontinente Pangea é a PEMP, no sudeste da América do Sul (Brasil, Argentina, Uruguai e Paraguai; Bellieni et al., 1984; Peate et al. 1990, 1992; Rämö et al., 2016) e sudoeste da África (Angola e Namíbia; Ewart et al., 2004; Gibson et al., 2005). Esta compreende magmatismo bimodal constituído principalmente por diques e derrames basálticos toleíticos, com menores ocorrências de rochas riolíticas. Na América do Sul, cobre uma área de aproximadamente $1,5 \times 10^{6} \mathrm{~km}^{2}$ da Bacia do Paraná, sudeste do Brasil (Florisbal et al., 2014; Rämö et al., 2016). As rochas da PEMP foram formadas no Cretáceo (134,6 Ma) e acredita-se que o intervalo de tempo de todo o magmatismo seja inferior a 1,2 Ma (Rene et al., 1992, 1996a, 1996b; Thiede e Vasconcelos, 2010).

À luz dessas informações, a principal característica utilizada para a separação entre a FM e a FS na Bacia do Parnaíba foi a idade de cristalização, com pouca ou nenhuma ênfase comparativa entre as características geoquímicas e isotópicas dessas rochas magmáticas. Este trabalho propõe uma caracterização geoquímica, isotópica e petrográfica dessas rochas com ênfase na distinção geoquímica entre as duas formações, sugerindo ainda a caracterização preliminar da gênese desses magmas. 


\subsection{Objetivos}

Esta dissertação de mestrado tem por objetivo principal a caracterização petrográfica, geoquímica e isotópica das formações basálticas da Bacia do Parnaíba, levando em conta sua distribuição espacial e relevância geológica no arcabouço geral de conhecimento da bacia. Com essa finalidade, foram traçadas metas secundárias:

1. Determinar se existe um padrão geográfico de ocorrência dos tipos de magma na bacia;

2. Gerar dados suficientes para que a discriminação das duas formações seja possível, levando-se em conta aspectos geoquímicos e petrográficos;

3. Correlacionar as formações Mosquito e Sardinha com províncias magmáticas conhecidas;

4. Propor a evolução petrogenética dos magmas existentes na bacia.

\subsection{Justificativa}

O projeto representa uma oportunidade única de pesquisadores e estudantes vinculados aos laboratórios de Estudos da Litosfera e Geocronologia contribuir para estudar um tópico que se situa na fronteira do conhecimento das Geociências: a origem de bacias cratônicas e as rochas ígneas associadas. A Bacia do Parnaíba, relativamente pouco conhecida, está sendo tomada como paradigma para compreender porque vastos interiores continentais, considerados estáveis, situados longe das zonas de interação de placas, em certos momentos de sua evolução passam por estágios de subsidência prolongada, abarcando intervalos de centenas de milhões de anos, ao longo dos quais, ainda que com ocasionais ou frequentes interrupções, são acumulados pacotes de rochas sedimentares com vários quilômetros de espessura, eventualmente associadas a manifestações vulcânicas, representadas principalmente por basaltos (de Castro et al., 2014).

No caso dos basaltos da Bacia do Parnaíba, o estudo petrológico desse importante magmatismo máfico permite conhecer com mais profundidade a natureza 
química/isotópica do manto que deu origem a ele, bem como aspectos que levaram à geração de hidrocarbonetos na bacia, ajudando na compreensão da evolução geológica da bacia e seus prospectos econômicos. 


\section{PETROLOGY OF JURASSIC AND CRETACEOUS BASALTIC FORMATIONS FROM THE PARNAÍBA BASIN, NE BRAZIL: CORRELATIONS AND LIP ASSOCIATIONS}

The Mosquito Formation (MF) and Sardinha Formation (SF) are basaltic occurrences in the Parnaíba Basin, Northeastern Brazil, related to the opening of the Atlantic Ocean at Jurassic/Triassic and Cretaceous age, respectively. The MF and SF are commonly associated with Continental Flood Basalt provinces such as the Central Atlantic Magmatic Province and the Paraná-Etendeka Magmatic Province. The MF comprises tholeiitic flows with high- and low-Ti nature, formed by two-pyroxene basalts, with petrogenetic characteristics related to HIMU and EM-type mantle reservoirs, respectively. Radiogenic $\mathrm{Sr}$ (0.70296-0.70841) and non-radiogenic to slightly radiogenic $\mathrm{Nd}$ (0.5121840.512677 ) isotopic compositions, associated with enrichment in large-ion lithophile (LIL) and high-field strength (HFS) elements relative to primitive mantle values comprises crucial aspects of the MF.

The SF is composed of high- and low-Ti tholeiitic dykes together with alkaline basaltic flows and dykes in lesser amount. The SF basalts and diabases are composed by augitic or diopsidic pyroxene associated to plagioclase and occasionally olivine. They have geochemical and isotopic features associated to HIMU and EM-type mantle endmembers. Most alkaline, high- and low-Ti SF basalts compositions range between 0.7047-0.7070 of initial Sr and 0.5123-0.5126 of initial Nd with enrichment in LIL and HFS elements relative to primitive mantle values.

Although the MF and SF share similarities, they can be differentiated taking into consideration trace element compositions such as $\mathrm{Nb}, \mathrm{Ta}, \mathrm{Pb}$ and $\mathrm{La} / \mathrm{Yb}$ ratios. Thus, petrographical characteristics and trace elements contents yield individual features intrinsic to each basalt formation that allows their discrimination in the Parnaíba Basin. The source for the Parnaíba Basin magmatism can be related to enriched mantle components bellow the Pangea supercontinent during the opening of the central and equatorial segments of the Atlantic Ocean.

Keywords: Intraplate Magmatism, Continental Flood Basalts, Basalt Geochemistry. 


\subsection{Introduction}

Large Igneous Provinces (LIPs) comprise voluminous $\left(>0.1 \mathrm{Mkm}^{3}\right)$ sets of igneous rocks of typically mafic composition covering large areas $\left(>0.1 \mathrm{Mkm}^{2}\right)$. LIPs evolve during fast episodes ( $<50 \mathrm{Ma}$ ) characterized by magmatic flows or pulses of short duration ( 1 $5 \mathrm{Ma}$ ) (Coffin and Eldholm, 1991; 1992; 1993a; 1993b; Bleeker and Ernst, 2006; Bryan and Ernst, 2008; Sheth, 2007). The well-studied LIPs are typically composed of Continental Flood Basalts (CFBs), which represent episodes of mafic magmatism, commonly related to mass extinction events and continental break-ups (White and Mackenzie, 1989; Courtillot and Renne, 2003). LIPs and CFBs have long been the object of many studies focusing on constraints about mantle properties and heterogeneities.

The Central Atlantic Magmatic Province (CAMP) is a major CFB event related to the opening of the Central Atlantic Ocean. It includes intrusive and extrusive tholeiitic rocks presently exposed in four continents (i.e., North and South America, Europe and Africa; Marzoli et al., 1999; McHone, 2000). The extrusion of CAMP basalts occurred at 200 Ma with distinct pulses occurring until about $190 \mathrm{Ma}$. Magmatism probably took place in less than $1 \mathrm{Ma}$ (Deckart et al., 1997; Jourdan et al., 2009; Marzoli et al., 1999). Dykes, sills and flows cover an area of up to $11 \times 10^{6} \mathrm{~km}^{2}$ (Marzoli et al., 1999). In South America, CAMP magmatism took place in Brazilian Paleozoic-Mesozoic basins (i.e., Amazon, Solimões and Parnaíba basins; Costa et al., 2012; Cunha et al., 2007; Eiras et al., 1994; Merle et al., 2011; Mizusaki et al., 2002), as well as covering Archean basement in the French Guiana, Surinam and Guyana (Deckart et al., 1997, 2005) and sub-Andean areas of Bolivia (Bertrand et al., 2014).

The most known CFB related to the break-up of Pangea is the Paraná-Etendeka Magmatic Province (PEMP), in southeastern South America (i.e., Brazil, Argentina, Uruguay and Paraguay; Bellieni et al., 1984; Peate et al., 1990, 1992; Rämö et al., 2016) and in southwestern Africa (i.e., Angola and Namibia; Ewart et al., 2004; Gibson et al., 2005). The PEMP comprises mainly tholeiitic with minor silicic lava flows and dykes. The South American PEMP covers an area of approximately $1.5 \times 10^{6} \mathrm{~km}^{2}$ of the Paraná Basin (Florisbal et al., 2014; Rämö et al., 2016). These rocks were formed in the Cretaceous 
(134.6 Ma) and the time interval of the entire PEMP magmatism is believed to be less than 1.2 Ma (Renne et al., 1992, 1996a, 1996b; Thiede and Vasconcelos, 2010).

In the Parnaíba Basin, the basaltic Mosquito and Sardinha formations rocks are coeval with CAMP and PEMP ages, respectively. Although several studies have demonstrated that the Mosquito Formation is a clear evidence of the CAMP magmatism in Brazil (Góes and Feijó, 1994; Marzoli et al., 1999; Merle et al., 2011), the same is not true for the association between the Sardinha basalts and the PEMP. The differences between the two formations are not straightforward in the field, and they are mainly recognized using radiometric ages. Some authors have considered that the Sardinha Formation correlates to the Serra Geral Formation mainly because of age similarity (Góes and Feijó, 1994; da Silva et al., 2003; Vaz et al., 2007). However, no petrologic studies have been published yet. In this work, we investigate basaltic rocks of the Parnaíba Basin in order to constrain the petrological characteristics of both formations and compare them to LIPs that they are commonly related to. For this purpose, we present petrographic, whole-rock geochemistry and Sr-Nd isotopic characteristics of 37 basalt samples of the Parnaíba Basin.

\subsection{Geological setting}

The Parnaíba Basin is a Phanerozoic sedimentary basin located in northeastern Brazil underlying an area of over $600.000 \mathrm{~km}^{2}$ with thickness of approximately $3.5 \mathrm{~km}$ of sedimentary rocks in its depocenter (Góes and Feijó, 1994; Vaz et al., 2007). The Parnaíba Basin is located between the Amazonian (Cordani et al., 2009), São Luiz (Klein et al., 2002) and São Francisco (Sial et al., 2010) cratons and the Neoproterozoic Borborema (Brito Neves et al., 2000; Van Schmus et al., 1995) and Tocantins orogens (Pimentel and Fuck, 1992; Pimentel et al., 2000) (Fig.1a). In recent studies by Daly et al (2014), a deep seismic profile has demonstrated that three continental crust blocks and an ophiolitic metasedimentary sequence underlies the Parnaíba Basin. They have been accreted during the Brasiliano Orogeny (Brito Neves et al., 1984). The Transbrasiliano Lineament is considered the main element triggering the early stages of sedimentation in the Parnaíba Basin and the formation of graben-like features (de Castro et al., 2014; de 
Oliveira and Mohriak, 2003). At least two distinct phases of compression are evident, one of Triassic and one of Late Jurassic/Early Cretaceous age (de Castro et al., 2014; Daly et al., 2014), close to the extrusion ages of the basaltic rocks recognized in the basin.

The Parnaíba Basin comprises four sub-basins with distinct origins, as described by Góes et al (1990). Its depositional ages vary from early Paleozoic to Mesozoic and includes five major siliciclastic sedimentary cycles separated by unconformities (Góes and Feijó, 1994; Góes et al., 1990; Vaz et al., 2007): (i) Silurian (Serra Grande Group), (ii) Mesodevonian-Eocarboniferous (Canindé Group), (iii) Neocarboniferous-Eotriassic (Balsas Group), (iv) Jurassic (Pastos Bons Formation) and (v) Cretaceous (Codó, Corda, Grajaú and Itapecuru Formations) (Fig.1b). The igneous rocks are included in the Mosquito and Sardinha Formations. They occur as dykes and sills mainly within the Mesodevonian-Eocarboniferous and Silurian sequences and as magmatic flows in the Jurassic and, less commonly, in the Cretaceous Sequence (Vaz et al., 2007; Fig.1a). The Jurassic Sequence marks the beginning of Pangea break-up and subsidence of the central portion of the basin where rift systems were installed and the depocenter is located today. Exposures of volcanic rocks occur mostly along a broad E-W zone in the central part of the basin but also along its NE and SE edges (de Castro et al., 2014).

Baksi \&Archibald (1997) separate the basaltic occurrences of the basin into a western section, where the Mosquito Formation is exposed, and an eastern section, with the Sardinha Formation. That was subsequently recognized by many workers and is still accepted, although some dykes and sills do not follow this general pattern (Fig.1a). The magmatic formations were formed during a two-stage opening of the Atlantic Ocean. The Mosquito Formation is related to the opening of the Central Atlantic Ocean in the Early Jurassic and the Sardinha Formation to the opening of the South Atlantic Ocean during the Cretaceous (Baksi and Archibald, 1997; Fodor et al., 1990; Góes and Feijó, 1994; Vaz et al., 2007). The Mosquito Formation is mainly composed of lava flows and some large sills in the western portion of the basin. The basaltic pile reaches $175 \mathrm{~m}$ in thickness (Almeida, 1986) and these rocks are commonly included in the CAMP event due to similarities in age (ca. 200 Ma; Baksi and Archibald, 1997; Marzoli et al., 1999; Mizusaki 

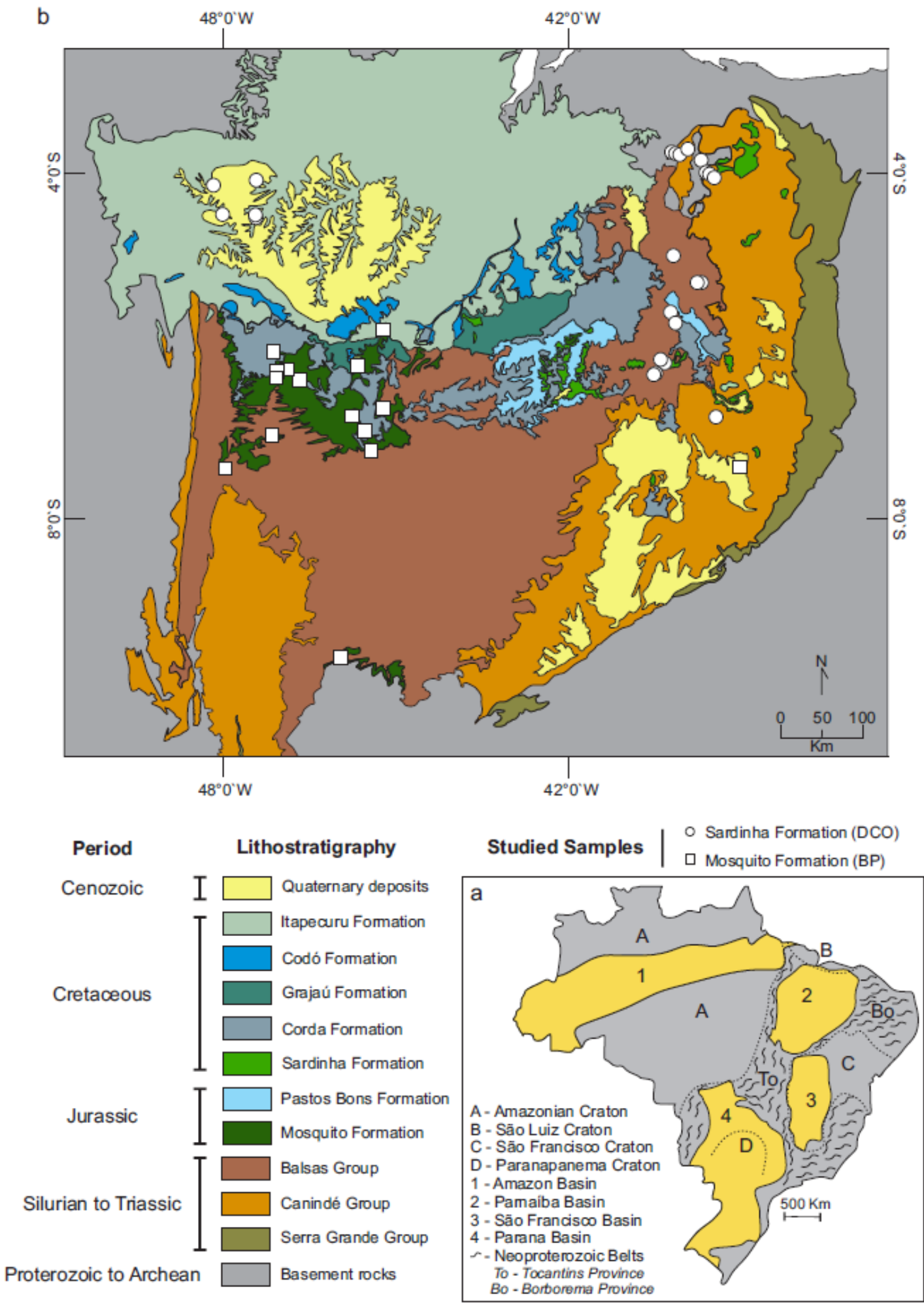

Figure 1 - a) Schematic map showing neoproterozoic Brazilian cratons, basins and orogenic belts (modified after Sadowski and Campanha, 2004; Zalán, 2004). b) Map and stratigraphy of the Parnaíba basin displaying sample location (modified after Angelim et al., 2004; Bahia et al., 2004; Faraco et al., 2004a, 2004b; Kosin et al., 2004; Vasconcelos et al., 2004a, 2004b; 2004c; 2004d). Basement rocks are undifferentiated but mainly composed of neoproterozoic orogenic belts (Borborema Province and Tocantins Province at the western and eastern margin, respectively). 
et al., 2002; Merle et al., 2011) with CAMP basalts of Africa, Europe and North America. Dykes and sills up to $400 \mathrm{~m}$ thick (Bellieni et al., 1990; Fodor et al., 1990) dominate the Sardinha Formation. These rocks yield K-Ar and Ar-Ar plateau ages (Baksi and Archibald, 1997; Mizusaki et al., 2002) analogous to those of the basalts of the Serra Geral Formation of the Paraná Basin (Piccirillo et al., 1989, 1990; Peate et al., 1990, 1992) at around 113.4 \pm 3.7 to $133 \pm 11 \mathrm{Ma}$.

\subsection{Analytical methods}

\subsubsection{Sampling, petrography and electron probe analyzes}

Samples were collected from dykes, sills and flows in order to cover representative outcrops known in the Parnaíba Basin. Only the freshest samples were analyzed. Thirtyseven thin sections were prepared at the University of Brasília (UnB), and described using petrographic microscopes. Olivine, clinopyroxene and plagioclase major element compositions of 23 samples were analyzed at the Electron Microprobe Laboratory of UnB by means of a 5-spectrometer JEOL JXA-8230 SuperProbe Electron Probe Micro analyzer. Analytical conditions consisted of $15 \mathrm{kV}$ of acceleration voltage and $10 \mathrm{nA}$ of beam current. The count times for peaks and backgrounds for all elements were $10 \mathrm{~s}$ and $5 \mathrm{~s}$, respectively. Results not constrained between $99-101 \%$ were discarded.

\subsubsection{Whole-rock geochemistry}

Major and trace element concentrations for samples of the Mosquito Formation were carried out at the Bureau Veritas Minerals Laboratories (BVML). Description of analytical methods is available at BVML Home Page (www.acmelab.com). Whole-rock geochemistry of the Sardinha Formation samples were performed at the ALS Minerals. Analytical methods include ICP-AES and ICP-MS for major oxides and trace elements (package codes: ME-ICP06 with OA-GRA05 and ME-MS81). Description of the methods used may be obtained from the ALS Home Page (www.alsglobal.com).

Twelve samples of the Mosquito Formation and twenty of the Sardinha Formation samples were analyzed for their whole rock geochemical characteristics. Samples are 
fresh although amygdules tend to increase the LOI (loss on ignition) values; for this reason three analyzes of the Mosquito Formation and one of the Sardinha Formation have LOI of more than $4 \%$ and were discarded.

\subsubsection{Isotopic analyzes}

Sm-Nd analyzes of fifteen samples of the Mosquito Formation were performed at the Geochronology Laboratory of the University of São Paulo (USP), Brazil using an ICPMS Thermo Neptune. Isotopic ratios $\left({ }^{143} \mathrm{Nd} /{ }^{144} \mathrm{Nd}\right)$ were normalized for fractionation using the value of ${ }^{146} \mathrm{Nd} /{ }^{144} \mathrm{Nd}=0.7219$ (DePaolo, 1981). Nd blank values during analyzes remained close to $80 \mathrm{pg}$. Uncertainties for ${ }^{143} \mathrm{Nd} /{ }^{144} \mathrm{Nd}$ ratios were better than 0.000009 $(2 \sigma)$, based on JNDi rock standard. Sr isotopes were measured on a Finnigan MAT 262 TIMS (Thermo lonization Mass Spectrometer) at the Geochronology Laboratory of the USP. Isotopic ratios were normalized to ${ }^{86} \mathrm{Sr} /{ }^{88} \mathrm{Sr}=0.1194 \mathrm{Sr}$ blank values were approximately $360 \mathrm{pg}$. Medium value for the used rock standard (NBS-987) was 0.710251 \pm 0.000038 . Sm-Nd analyzes of the Sardinha Formation were performed at the Geochronology Laboratory of the UnB following the method described by Gioia and Pimentel (2000). Sm-Nd measurements of twenty-one whole-rock samples of the Sardinha Formation using a ${ }^{149} \mathrm{Sm}-{ }^{150} \mathrm{Nd}$ mixed spike. Cation exchange Teflon columns packed with polytetrafluorethylene powder, impregnated with DI-(2-etilexil) phosphoric acid were used to separate $\mathrm{Sm}$ and $\mathrm{Nd}$ fractions of the samples. The samples were loaded on a Re double-filament assembly and measured using a Thermo Triton mass spectrometer. Uncertainties for ${ }^{147} \mathrm{Sm} /{ }^{144} \mathrm{Nd}$ and ${ }^{143} \mathrm{Nd} /{ }^{144} \mathrm{Nd}$ ratios are better than $\pm 0.2 \%$ $(2 \sigma)$ and $\pm 0.0005 \%(2 \sigma)$, respectively, based on analyzes of the BHVO-1 international rock standard. Analyzes that yielded larger errors were discarded. The ${ }^{143} \mathrm{Nd} /{ }^{144} \mathrm{Nd}$ ratio was normalized using ${ }^{146} \mathrm{Nd} /{ }^{144} \mathrm{Nd}=0.7219$. TDM model ages were calculated by using the procedure in DePaolo (1981). The Sr isotopic compositions were obtained on sixteen samples using a Thermo Triton mass spectrometer at UnB. The $2 \sigma$ uncertainties for ${ }^{87} \mathrm{Sr} /{ }^{86} \mathrm{Sr}$ values were smaller than $0.01 \%$. 


\subsection{Magmatism of the Parnaíba Basin}

The Mosquito and Sardinha Formations are exposed in the western and eastern portions of the basin, respectively (Fig. 1). However, this general distribution is not straightforward, as there are sills and dykes that do not follow this geographical pattern. The classification of rocks was made taking into consideration their $\mathrm{TiO}_{2}$ contents. This chemical characterization also reflects differences in petrography and isotopes. Mineral chemistry data do not allow a clear distinction between the two groups due to the zoning in crystals, which yielded a very broad range of compositions. Nevertheless, it could provide information regarding the magmatic and geothermometry of the rocks.

Overall, the Mosquito and Sardinha magmatic rocks can be distinguished mostly by petrographic and geochemical differences. On a preliminary basis, most of the Parnaíba magmatic rocks are sub-alkaline tholeiitic basalts (Fig.2). The Mosquito Formation basalts have lower alkalis contents when compared with the Sardinha Formation rocks. It is worth mentioning that four Sardinha Formation samples plot on the alkaline series side of the TAS diagram (Fig.2a) as basalt, trachybasalt or tephrite/basanite and therefore they were not added to Fig. 2b. The remaining basalt samples characterize a tholeiitic trend for both the Mosquito and Sardinha formations (Fig.2b). Therefore, magmatism of the Parnaíba Basin is mostly composed of tholeiitic basalts with subordinate alkali-basalts. 

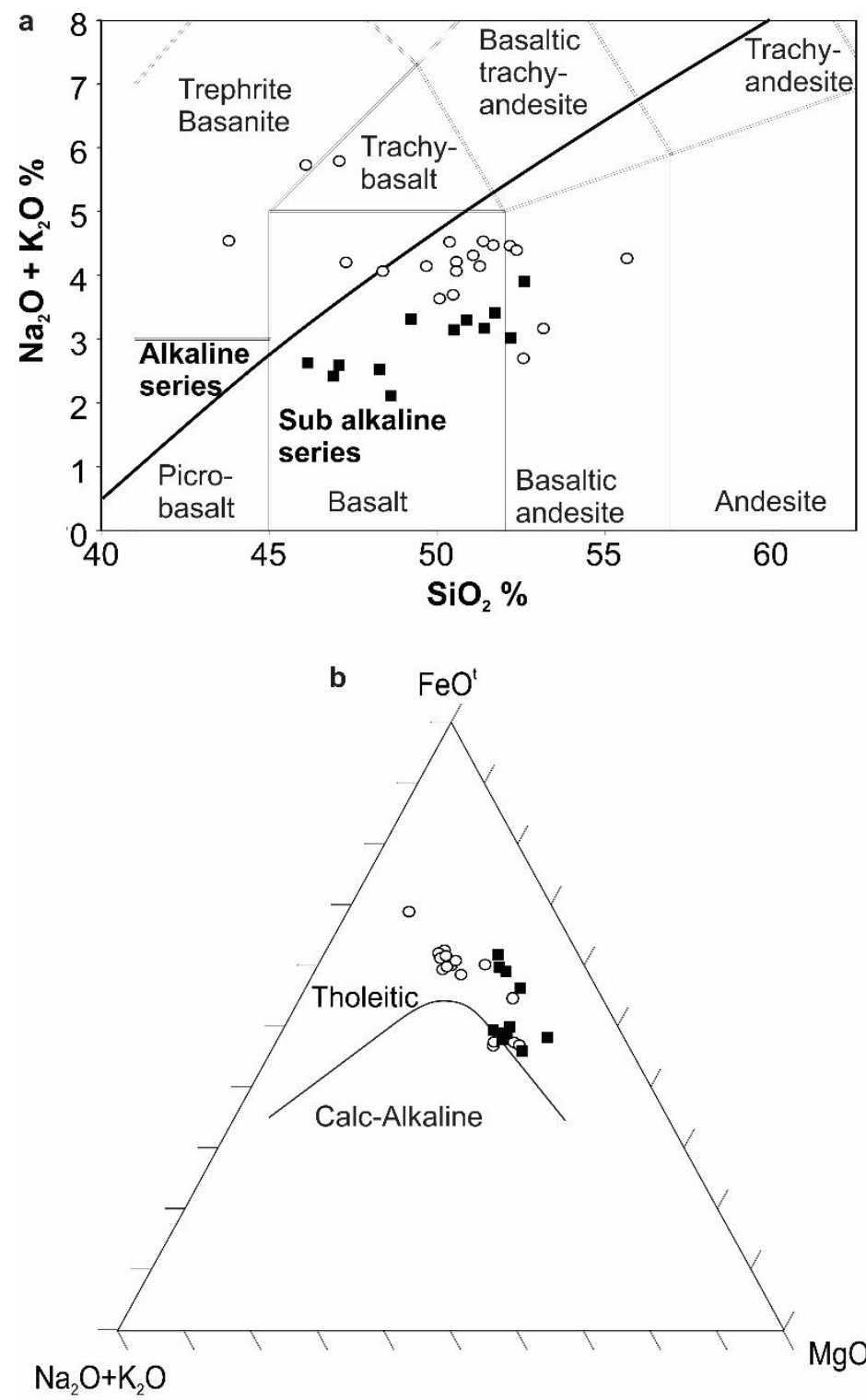

- Sardinha Formation a Mosquito Formation

Figure 2 - a) Total alkali vs silica diagram showing the alkaline and sub-alkaline fields (after Irvine and Baragar, 1971; Le Bas et al., 1986); b) AFM (alkalis, iron and magnesium) ternary diagram, discriminating tholeiitic and calc-alkaline series (Irvine and Baragar, 1971).

\subsubsection{Mosquito Formation}

\subsubsection{Petrography}

The Mosquito Formation is formed mainly by lava flows (Fig.3a), occasionally interbedded with sandstones. Samples are predominantly amygdaloidal basalts (Fig.3b) 
and less frequently massive textured basalts. Mineral assemblage of the Mosquito Formation rocks consists of two pyroxenes (augite and pigeonite), plagioclase, $\mathrm{Fe}-\mathrm{Ti}$ oxides (magnetite with exsolved ilmenite), volcanic glass and vesicles/amygdules filled by calcite, quartz or zeolite. Apatite, pyrite and chalcopyrite occur as minor phases and rare alkali-feldspar characterizes late stage crystallization. Clinopyroxene and plagioclase show signs of magmatic zonation. Secondary minerals are white mica and amphibole formed after alteration of plagioclase and clinopyroxene, respectively.

Two main types of texture are found and reflect differences in mineralogy: (i) twopyroxene with ophitic to subophitic textures in a fine-grained clinopyroxene, plagioclase, devitrified glass and $\mathrm{Fe}-\mathrm{Ti}$ oxide matrix with intersertal texture; vesicles/amygdules are frequent and filled by calcite, quartz or zeolite (Fig.3c, d); (ii) Ophitic or poikilitic phenocrysts which may be either clinopyroxene (augite) or plagioclase associated with a fine-grained intersertal matrix (Fig.3e, f); rare amygdules are filled by calcite. These two groups of basalts form the Mosquito Formation and have chemical differences that will be discussed further.

\subsubsection{Mineral chemistry}

Phenocrysts were analyzed taking into consideration the two petrographic groups in order to constrain the composition and extent of zonation (Fig.3d, e) present in the minerals that represent the early crystallization phases of these rocks. Mg\# (Mg x $100 /$ $\left.\left(\mathrm{Mg}+\mathrm{Fe}^{2+}\right)\right)$ was used to investigate the clinopyroxene composition. Augite crystals from group (i) show a wide Mg\# variation with phenocrysts ranging from 87 to 42 . Pigeonite

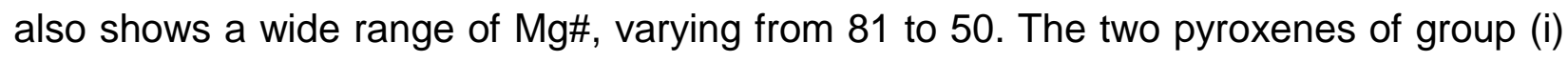
show negative correlation between $\mathrm{Mg} \#$ and $\mathrm{TiO}_{2}$ (Fig.4). This suggests that $\mathrm{Ti}$ remains incompatible during the co-precipitation of the two pyroxenes and Ti-oxide saturation was not attained at early stages. Mg\# of augite crystals of group (ii) vary from 83 to 74 in phenocrysts and only one pigeonite analysis yielded Mg\# of 49. A two-pyroxene (QUILF; Andersen et al., 1993) geothermometer (relative to 0.2-0.3 GPa) was applied to group (i) rocks and indicated the equilibrium temperature between approximately 1195 to $1060^{\circ} \mathrm{C}$, similar to results obtained by Callegaro et al. (2014) for European CAMP rocks. Geothermometry was not applied to group (ii) basalts due to the small number of pigeonite 
analyzes.
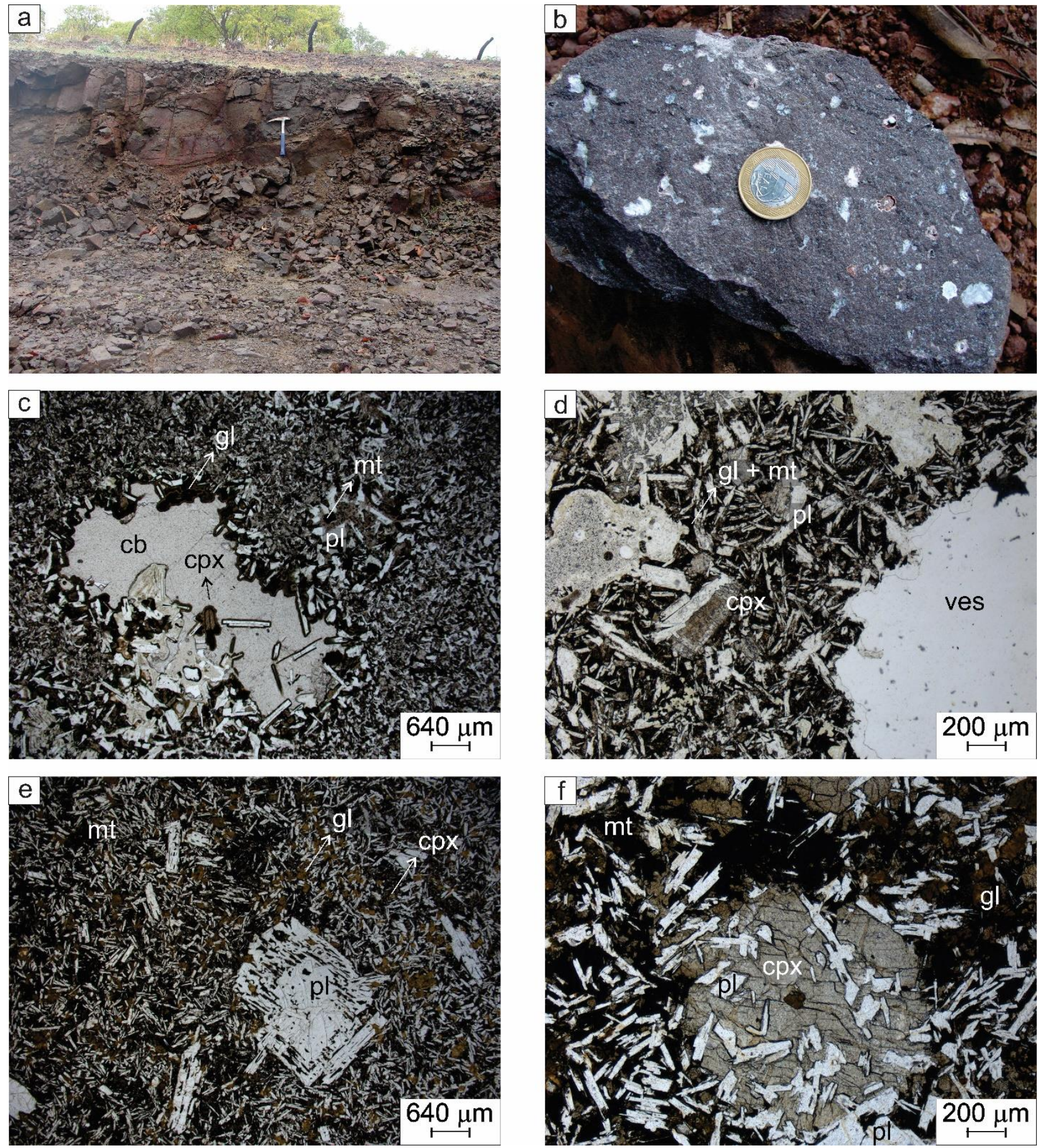

Figure 3 - Overall aspects of the Mosquito Formation. a) lava flow outcrop; b) typical amygdaloidal basalt; c) low-Ti basalt with highlighted mineral assemblage and calcite amygdule; d) low-Ti basalt with similar mineral assemblage shown on figure $c$ but with unfilled vesicle; note that on both figure $c$ and $d$, mineral sizes do not vary much and are mostly smaller than 200 $\mathrm{m}$ across. e) high-Ti basalt with zoned porphyritic plagioclase; f) high-Ti basalt with ophitic texture displaying a larger clinopyroxene crystal with plagioclase inclusions. Micro petrographic photos were taken with parallel polarizers. $\mathrm{Pl}=$ plagioclase, $c p x=$ clinopyroxene, $m t=$ magnetite $(F e-T i$ oxide), $g l=$ volcanic glass, ves $=$ vesicle , $c b=$ carbonate (calcite). 


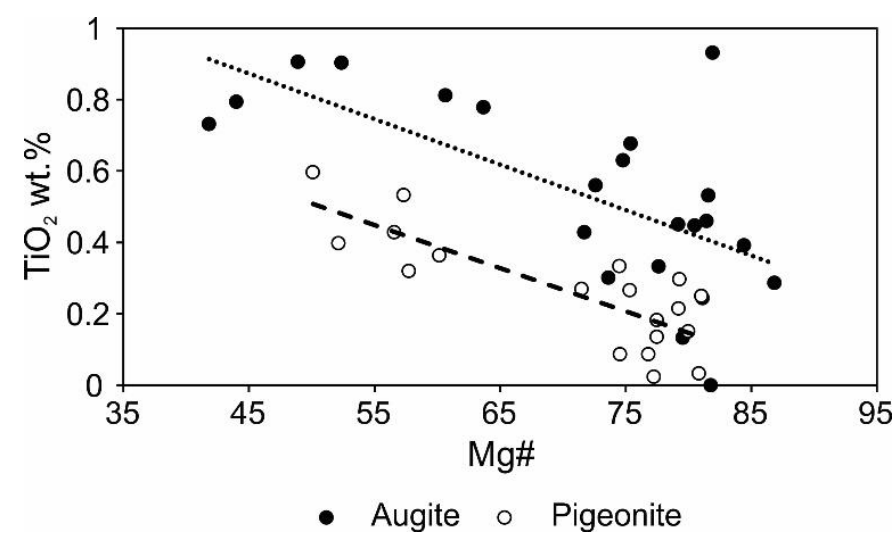

Figure 4 - Mg\# vs $\mathrm{TiO}_{2} \%$ low-Ti basalts of the Mosquito Formation showing negative trends both on augite and pigeonite crystals. $\mathrm{TiO}_{2}$ saturation was not obtained on these early stages of crystal development. Dotted and dashed lines represents augite and pigeonite linear trends, respectively.

Plagioclase phenocrysts in group (i) rocks show compositional variation from bytownite to labradorite (An74-52Ab26-46Oro.2-4). Plagioclase phenocrysts in one sample from group (ii) also yielded composition from bytownite to labradorite (An77-64Ab22-36Oro.20.5). Compositions poorer in An were observed towards the rims of phenocrysts.

\subsubsection{Major and trace elements}

There are two clusters of major element data in the analyzed samples, based on $\mathrm{SiO}_{2}$ and $\mathrm{TiO}_{2}$ contents. These two groups correlate with petrographic groups (i) and (ii) described above. Group (i) comprises rocks with $>50.21$ wt. $\% \mathrm{SiO}_{2}$ and $<1.5$ wt.\% $\mathrm{TiO}_{2}$, and group (ii) basalts present $<48.28$ wt. $\% \mathrm{SiO}_{2}$ and $>1.5$ wt.\% $\mathrm{TiO}_{2}$ (Fig.5). Groups (i) and (ii) are here referenced as low and high-Ti basalts respectively. Major and trace element contents of representative samples within the groups are displayed in Table 1.

Quartz/hypersthene-normative rocks represent the low-Ti group. They have relatively high $\mathrm{Na}_{2} \mathrm{O}+\mathrm{K}_{2} \mathrm{O}$, low $\mathrm{Fe}_{2} \mathrm{O}_{3} \mathrm{t}$ and $\mathrm{MnO}$ contents (Fig. $5 \mathrm{c}, \mathrm{d}, \mathrm{g}$ ). $\mathrm{Al}_{2} \mathrm{O}_{3}$ ranges from 13.13 to 14.48 wt.\% (Fig.5e) and MgO contents are low (6.55-7.55 wt.\%; Fig.5a). The high-Ti group comprises olivine/hypersthene-normative basalts that have lower $\mathrm{SiO}_{2}, \mathrm{MnO}$ and $\mathrm{Na}_{2} \mathrm{O}+\mathrm{K}_{2} \mathrm{O}$ with higher $\mathrm{Fe}_{2} \mathrm{O}_{3}$ t and $\mathrm{CaO}$ (Fig.5c, d, f, g), in addition to varied $\mathrm{Al}_{2} \mathrm{O}_{3}$ (i.e., 12.79-15.15 wt.\%; Fig.5e) and MgO contents (i.e., 7.30-4.97 wt.\%; Fig.5a). Mg\# $\left(100^{*} \mathrm{MgO} /\left(\mathrm{MgO}+\mathrm{Fe}_{2} \mathrm{O}_{3}{ }^{\mathrm{t}}\right)\right.$ is a major discriminant between the two groups. Low-Ti basalts have Mg\# values from 44 to 36 , whereas high-Ti range from 33 to 25 (Fig.5h). 

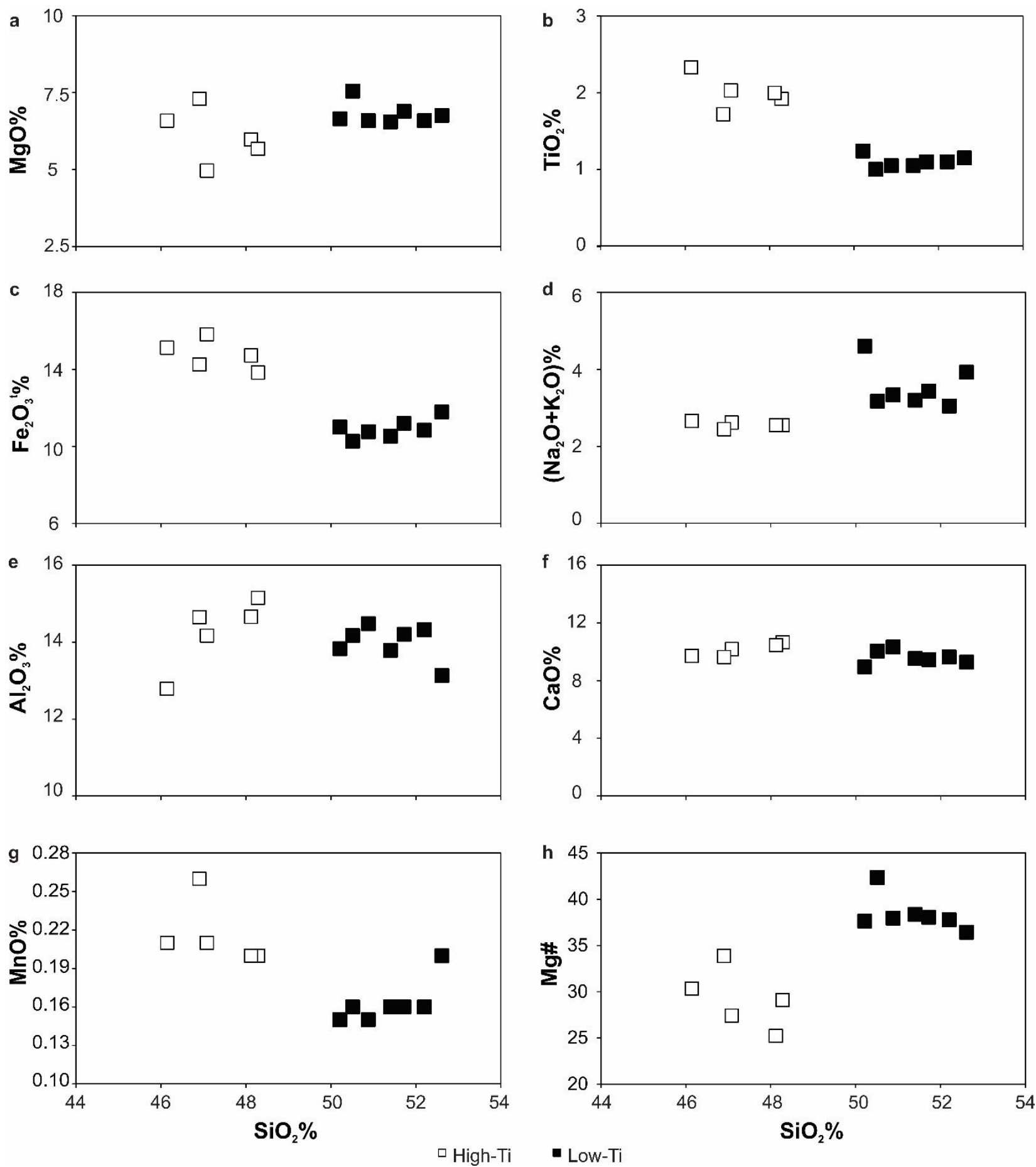

Figure 5 - Major element vs silica diagrams for the Mosquito Formation tholeiites. The two compositional groups of high and low-Ti illustrate are clearly distinct with respect to their major element compositions.

Trace elements also reveal differences between the two groups as demonstrated by the multi-element diagrams (Fig.6) normalized to primitive mantle (PM) and chondrite (CH) (PM: Sun and McDonough, 1989; CH: McDonough and Sun, 1995). As shown in Fig.6a, low-Ti rocks display high values of LILE (Large lon Lithophile Elements) and less 
enriched contents of HFSE (High Field Strength Elements). They display positive Rb, $\mathrm{Ba}$, $\mathrm{K}$ and $\mathrm{Pb}$ anomalies (30 to 60 times higher than $\mathrm{PM}$ values). One sample (BP-56A) yielded negative $\mathrm{Pb}$ anomaly associated with high $\mathrm{Sr}$ content. Additionally, sample BP-35 shows a positive $\mathrm{P}$ anomaly, not characteristic of the other low-Ti rocks. Moderate LREE (Light Rare Earth Elements) enrichment in comparison to HREE (Heavy Rare Earth Elements) is characteristic of the low-Ti basalts (i.e., $\mathrm{LacH} / \mathrm{YbCH}_{\mathrm{CH}}=3.2-4.1$; Fig.6c).
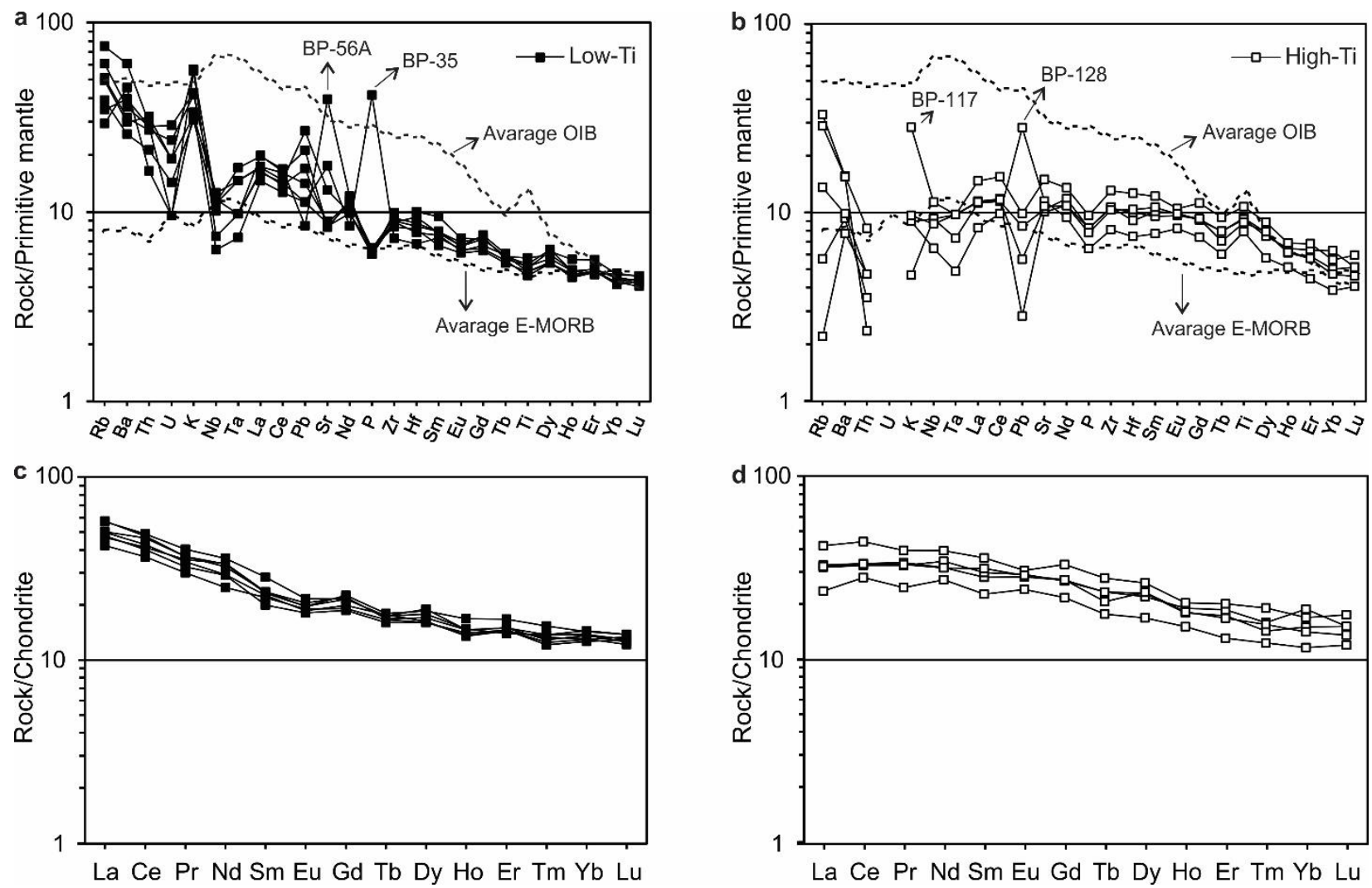

Figure 6 - Multi-element diagrams for the Mosquito Formation samples. Primitive mantle normalizing values, OIB and MORB compositions are after Sun and McDonough (1989), chondrite normalizing values are after McDonough and Sun (1995). a) Primitive mantle normalized diagram for low-Ti Mosquito Formation displays a broad positive K anomaly, with the characteristic CAMP Nb-Ta negative anomaly and negative $P$ anomaly (with the exception of sample BP-35). b) Primitive mantle normalized diagram for high-Ti Mosquito basalts showing scattered LILE values with homogeneous HFSE, Nb-Ta and $P$ (except samples BP-128) negative anomalies. c) and d) Chondrite normalized diagram for the Mosquito Formation rocks (symbols as in a and b).

High-Ti basalts show lower LILE contents except for Rb (which displays scattered results) and higher contents of HFSE (in some cases enriched more than 10 times the PM values; Fig.6b). They display variable $\mathrm{Rb}$ contents and negative $\mathrm{Nb}-\mathrm{Ta}$ and $\mathrm{Pb}$ anomaly. Sample BP-117 yielded positive Rb, Th and K anomalies; this sample presents the highest LOI value (3.90 wt.\%) which may represent a stronger degree of alteration. High-Ti basalts 
Table 1 - Compositions of whole-rock samples from the Mosquito Formation.

\begin{tabular}{|c|c|c|c|c|c|c|c|}
\hline Sample & $\begin{array}{l}\text { BP-02 } \\
\text { Low-Ti }\end{array}$ & $\begin{array}{l}\text { BP-08 } \\
\text { Low-Ti }\end{array}$ & $\begin{array}{l}\text { BP-35 } \\
\text { Low-Ti }\end{array}$ & $\begin{array}{l}\text { BP-39 } \\
\text { Low-Ti }\end{array}$ & $\begin{array}{l}\text { BP-54 } \\
\text { Low-Ti }\end{array}$ & $\begin{array}{l}\text { BP-56A } \\
\text { Low-Ti }\end{array}$ & $\begin{array}{l}\text { BP-61A } \\
\text { Low-Ti }\end{array}$ \\
\hline $\mathrm{SiO}_{2}$ (wt.\%) & 49.71 & 51.40 & 50.51 & 48.62 & 52.61 & 50.21 & 50.88 \\
\hline $\mathrm{TiO}_{2}$ & 1.06 & 1.05 & 1.00 & 0.94 & 1.15 & 1.24 & 1.05 \\
\hline $\mathrm{Al}_{2} \mathrm{O}_{3}$ & 14.01 & 13.79 & 14.17 & 14.00 & 13.13 & 13.83 & 14.48 \\
\hline $\mathrm{Fe}^{2 \mathrm{O}}{ }^{*}$ & 10.73 & 10.52 & 10.27 & 10.52 & 11.79 & 11.01 & 10.77 \\
\hline MnO & 0.16 & 0.16 & 0.16 & 0.16 & 0.20 & 0.15 & 0.15 \\
\hline MgO & 6.51 & 6.55 & 7.55 & 7.91 & 6.76 & 6.65 & 6.59 \\
\hline $\mathrm{CaO}$ & 10.20 & 9.53 & 10.06 & 11.20 & 9.28 & 8.96 & 10.33 \\
\hline $\mathrm{Na}_{2} \mathrm{O}$ & 1.56 & 1.92 & 2.16 & 1.76 & 2.26 & 2.91 & 2.41 \\
\hline $\mathrm{K}_{2} \mathrm{O}$ & 0.96 & 1.28 & 1.01 & 0.38 & 1.67 & 1.70 & 0.92 \\
\hline $\mathrm{P}_{2} \mathrm{O}_{5}$ & 0.14 & 0.13 & 0.90 & 0.90 & 0.13 & 0.13 & 0.14 \\
\hline LOI & 4.80 & 3.40 & 2.70 & 4.20 & 0.80 & 2.90 & 2.10 \\
\hline Total & 99.84 & 99.73 & 100.49 & 100.59 & 99.78 & 99.69 & 99.82 \\
\hline Sc (ppm) & 36 & 36 & 35 & 39 & 39 & 37 & 37 \\
\hline V & 255 & 254 & 275 & 269 & 377 & 301 & 261 \\
\hline $\mathrm{Ba}$ & 189 & 276 & 316 & 85 & 250 & 423 & 180 \\
\hline $\mathrm{Sr}$ & 258 & 275 & 369 & 251 & 184 & 829 & 178 \\
\hline $\mathbf{Y}$ & 22 & 22 & 27 & 15 & 26 & 22 & 23 \\
\hline $\mathrm{Zr}$ & 94 & 100 & 81 & 66 & 100 & 111 & 93 \\
\hline $\mathrm{Cr}$ & 150 & 170 & 333 & 435 & 48 & 326 & 163 \\
\hline Co & 42 & 42 & 42 & 44 & 43 & 47 & 38 \\
\hline $\mathrm{Ni}$ & 5 & 7 & 11 & 11 & 14 & 19 & 20 \\
\hline $\mathrm{Cu}$ & 88 & 94 & 76 & 75 & 58 & 29 & 38 \\
\hline $\mathrm{Zn}$ & 31 & 26 & 29 & 18 & 33 & 26 & 30 \\
\hline $\mathrm{Ga}$ & 16 & 14 & 14 & 16 & 15 & 16 & 14 \\
\hline $\mathbf{R b}$ & 24 & 22 & 19 & 8 & 38 & 48 & 25 \\
\hline $\mathrm{Nb}$ & 7 & 8 & 5 & 4 & 5 & 8 & 7 \\
\hline Mo & 0.1 & $<0.1$ & 0.1 & $<0.1$ & 0.1 & $<0.1$ & $<0.1$ \\
\hline Cs & 0.2 & 0.1 & 0.2 & 1.0 & 0.5 & 0.5 & 0.2 \\
\hline La & 11.2 & 11.8 & 10.0 & 8.4 & 11.1 & 13.5 & 11.3 \\
\hline $\mathrm{Ce}$ & 26.7 & 26.2 & 22.5 & 17.9 & 25.3 & 29.9 & 24.6 \\
\hline $\mathrm{Pr}$ & 2.98 & 3.19 & 2.78 & 2.30 & 3.28 & 3.74 & 3.00 \\
\hline Nd & 12.8 & 13.4 & 11.4 & 10.3 & 15.4 & 16.4 & 13.3 \\
\hline Sm & 3.2 & 3.4 & 3.3 & 2.5 & 3.5 & 4.2 & 3.0 \\
\hline Eu & 1.15 & 1.05 & 1.07 & 1.05 & 1.11 & 1.22 & 1.02 \\
\hline Gd & 3.9 & 4.0 & 3.8 & 3.1 & 4.3 & 4.3 & 3.7 \\
\hline $\mathrm{Tb}$ & 0.6 & 0.6 & 0.6 & 0.5 & 0.6 & 0.6 & 0.6 \\
\hline Dy & 3.9 & 4.0 & 4.0 & 3.2 & 4.7 & 4.4 & 4.0 \\
\hline Ho & 0.7 & 0.7 & 0.8 & 0.5 & 0.8 & 0.8 & 0.8 \\
\hline Er & 2.1 & 2.3 & 2.3 & 1.7 & 2.4 & 2.2 & 2.3 \\
\hline $\mathrm{Tm}$ & 0.3 & 0.3 & 0.3 & 0.2 & 0.3 & 0.3 & 0.3 \\
\hline $\mathrm{Yb}$ & 2.0 & 2.1 & 2.0 & 1.4 & 2.2 & 2.3 & 2.1 \\
\hline Lu & 0.30 & 0.30 & 0.32 & 0.21 & 0.32 & 0.34 & 0.33 \\
\hline $\mathrm{Hf}$ & 3.0 & 2.4 & 2.1 & 1.9 & 2.6 & 3.1 & 2.5 \\
\hline $\mathrm{Ta}$ & 0.3 & 0.6 & 0.3 & 0.3 & 0.4 & 0.7 & 0.4 \\
\hline $\mathrm{Pb}$ & 2.5 & 1.9 & 0.8 & 1.6 & 0.8 & 0.6 & 1.2 \\
\hline Th & 2.3 & 2.4 & 1.4 & 1.6 & 2.4 & 2.5 & 1.8 \\
\hline
\end{tabular}


Table 1 - Continued

\begin{tabular}{|c|c|c|c|c|c|c|c|c|}
\hline Sample & $\begin{array}{c}\text { BP-119A } \\
\text { Low-Ti }\end{array}$ & $\begin{array}{c}\text { BP- } \\
\text { 121H1 } \\
\text { Low-Ti }\end{array}$ & $\begin{array}{l}\text { BP-129 } \\
\text { Low-Ti }\end{array}$ & $\begin{array}{c}\text { BP-19 } \\
\text { High-Ti }\end{array}$ & $\begin{array}{c}\text { BP-30 } \\
\text { High-Ti }\end{array}$ & $\begin{array}{l}\text { BP-117 } \\
\text { High-Ti }\end{array}$ & $\begin{array}{l}\text { BP-128 } \\
\text { High-Ti }\end{array}$ & $\begin{array}{l}\text { BP-156 } \\
\text { High-Ti }\end{array}$ \\
\hline $\mathrm{SiO}_{2}$ (wt. \%) & 49.22 & 51.72 & 52.20 & 47.08 & 48.12 & 46.14 & 46.90 & 48.28 \\
\hline $\mathrm{TiO}_{2}$ & 1.08 & 1.10 & 1.12 & 2.03 & 2.00 & 2.33 & 1.72 & 1.92 \\
\hline $\mathrm{Al}_{2} \mathrm{O}_{3}$ & 14.07 & 14.20 & 14.32 & 14.17 & 14.66 & 12.79 & 14.65 & 15.15 \\
\hline $\mathrm{Fe2O3}^{*}$ & 9.99 & 11.21 & 10.85 & 15.83 & 14.73 & 15.13 & 14.26 & 13.84 \\
\hline MnO & 0.16 & 0.16 & 0.16 & 0.21 & 0.20 & 0.21 & 0.26 & 0.20 \\
\hline $\mathrm{MgO}$ & 6.32 & 6.89 & 6.59 & 5.98 & 4.97 & 6.59 & 7.30 & 5.68 \\
\hline $\mathrm{CaO}$ & 10.38 & 9.45 & 9.64 & 10.19 & 10.46 & 9.71 & 9.64 & 10.65 \\
\hline $\mathrm{Na}_{2} \mathrm{O}$ & 1.99 & 2.19 & 2.08 & 2.35 & 2.41 & 1.81 & 2.18 & 2.26 \\
\hline $\mathrm{K}_{2} \mathrm{O}$ & 1.35 & 1.25 & 0.97 & 0.27 & 0.14 & 0.85 & 0.27 & 0.29 \\
\hline $\mathrm{P}_{2} \mathrm{O}_{5}$ & 0.16 & 0.14 & 0.14 & 0.18 & 0.18 & 0.21 & 0.14 & 0.17 \\
\hline LOI & 5.10 & 1.50 & 1.70 & 1.50 & 1.90 & 3.90 & 2.50 & 1.30 \\
\hline Total & 99.82 & 99.81 & 99.77 & 99.79 & 99.77 & 99.67 & 99.82 & 99.74 \\
\hline Sc (ppm) & 37 & 38 & 38 & 40 & 39 & 41 & 34 & 37 \\
\hline V & 266 & 273 & 266 & 455 & 444 & 512 & 386 & 424 \\
\hline $\mathrm{Ba}$ & 252 & 220 & 208 & 65 & 54 & 109 & 108 & 69 \\
\hline $\mathrm{Sr}$ & 173 & 175 & 188 & 212 & 220 & 316 & 242 & 227 \\
\hline$Y$ & 21 & 25 & 25 & 28 & 30 & 33 & 21 & 28 \\
\hline $\mathrm{Zr}$ & 96 & 99 & 104 & 119 & 120 & 146 & 91 & 115 \\
\hline $\mathrm{Cr}$ & 129 & 170 & 150 & 68 & 61 & 150 & 54 & 61 \\
\hline Co & 39 & 42 & 40 & 50 & 54 & 45 & 48 & 51 \\
\hline $\mathrm{Ni}$ & 23 & 15 & 13 & 81 & 68 & 25 & 47 & 86 \\
\hline $\mathrm{Cu}$ & 49 & 27 & 22 & 226 & 203 & 257 & 195 & 207 \\
\hline $\mathrm{Zn}$ & 40 & 32 & 42 & 75 & 70 & 43 & 46 & 63 \\
\hline $\mathrm{Ga}$ & 16 & 15 & 15 & 20 & 21 & 20 & 19 & 19 \\
\hline $\mathbf{R b}$ & 24 & 32 & 31 & 4 & 1 & 21 & 18 & 9 \\
\hline $\mathrm{Nb}$ & 10 & 8 & 9 & 7 & 7 & 8 & 5 & 6 \\
\hline Mo & 0.2 & 0.2 & 0.3 & 0.4 & 0.3 & 0.1 & 0.2 & 0.2 \\
\hline Cs & $<0.1$ & 0.6 & 0.3 & $<0.1$ & $<0.1$ & 0.3 & $<0.1$ & 0.9 \\
\hline La & 14.4 & 13.6 & 11.9 & 7.9 & 7.7 & 10.1 & 5.7 & 7.8 \\
\hline $\mathrm{Ce}$ & 28.1 & 29.1 & 28.5 & 20.9 & 20.4 & 27.5 & 17.5 & 20.7 \\
\hline $\mathrm{Pr}$ & 3.64 & 3.41 & 3.42 & 3.19 & 3.08 & 3.72 & 2.33 & 3.12 \\
\hline Nd & 15.0 & 15.3 & 14.8 & 14.8 & 16.0 & 18.3 & 12.7 & 14.7 \\
\hline Sm & 3.5 & 3.4 & 3.5 & 4.2 & 4.5 & 5.4 & 3.4 & 4.7 \\
\hline Eu & 1.16 & 1.11 & 1.16 & 1.62 & 1.67 & 1.76 & 1.38 & 1.65 \\
\hline Gd & 4.1 & 4.5 & 4.4 & 5.5 & 5.4 & 6.7 & 4.4 & 5.5 \\
\hline $\mathrm{Tb}$ & 0.6 & 0.7 & 0.6 & 0.9 & 0.9 & 1.0 & 0.7 & 0.8 \\
\hline Dy & 4.1 & 4.6 & 4.2 & 5.8 & 5.5 & 6.6 & 4.2 & 5.8 \\
\hline Ho & 0.7 & 0.9 & 0.8 & 1.0 & 1.1 & 1.1 & 0.8 & 1.0 \\
\hline Er & 2.1 & 2.7 & 2.4 & 2.8 & 3.0 & 3.3 & 2.1 & 2.7 \\
\hline $\mathrm{Tm}$ & 0.3 & 0.4 & 0.3 & 0.4 & 0.4 & 0.5 & 0.3 & 0.4 \\
\hline $\mathrm{Yb}$ & 2.0 & 2.3 & 2.2 & 2.5 & 3.1 & 2.8 & 1.9 & 2.3 \\
\hline Lu & 0.32 & 0.34 & 0.31 & 0.38 & 0.38 & 0.44 & 0.30 & 0.34 \\
\hline $\mathrm{Hf}$ & 2.6 & 2.9 & 2.7 & 3.1 & 2.8 & 3.9 & 2.3 & 3.2 \\
\hline $\mathrm{Ta}$ & 0.6 & 0.4 & 0.6 & 0.4 & 0.3 & 0.4 & 0.2 & 0.4 \\
\hline $\mathrm{Pb}$ & 1.7 & 1.5 & 1.0 & 0.2 & 0.6 & 0.7 & 2.0 & 0.4 \\
\hline Th & 2.1 & 2.3 & 2.7 & 0.3 & 0.4 & 0.7 & $<0.2$ & 0.4 \\
\hline
\end{tabular}


show slight LREE enrichment in comparison to HREE (i.e., $\mathrm{LaCH} / \mathrm{YbCH}=2.0-2.4$; Fig.6d). Negative $\mathrm{Nb}-\mathrm{Ta}$ anomalies, characteristic of CAMP rocks (cf. Bertrand et al., 2014; Callegaro et al., 2013, 2014; Chabou et al., 2010; Merle et al., 2011), are present in both groups.

\subsubsection{Sr-Nd isotopes}

Twelve samples of the Mosquito Formation were selected for $\mathrm{Sr}$ and $\mathrm{Nd}$ isotopic analyzes seven of the low-Ti group and five of high-Ti group. Isotopic values were corrected to $200 \mathrm{Ma}$ using the trace element contents of ICPMS analyzes. The Sr-Nd isotopic compositions are shown in Table 2. The two data groups produced a flat pattern of the isotopic composition with varied $\mathrm{Sr}$ and homogeneous Nd ratios (Fig. 7). Generally, high-Ti rocks yield high initial ${ }^{143} \mathrm{Nd} /{ }^{144} \mathrm{Nd}(200 \mathrm{Ma})(0.512632-0.512677)$ and low initial ${ }^{87} \mathrm{Sr} /{ }^{86} \mathrm{Sr}$ (200 Ma) (0.70296-0.70409) values, in contrast with lower initial ${ }^{143} \mathrm{Nd} /{ }^{144} \mathrm{Nd}(200 \mathrm{Ma})$ ratios $(0.512245-0.512272)$ and high initial ${ }^{87} \mathrm{Sr} / 86 \mathrm{Sr}_{(200 \mathrm{Ma})}(0.70650-0.70841)$ values of the low-Ti group. Notably, sample BP-117 has the highest $\mathrm{K}_{2} \mathrm{O}, \mathrm{Ba}, \mathrm{Rb}$ and LOI values of the high-Ti group, which in association with its higher radiogenic Sr values, may represent the most crust-contaminated high-Ti basalt studied.

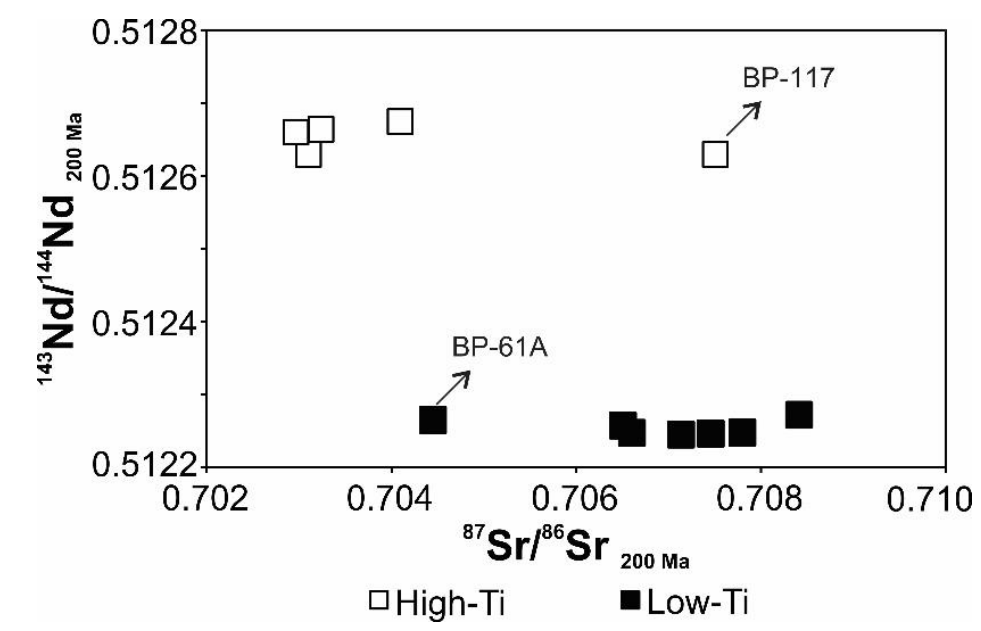

Figure 7 - Mosquito Formation initial ${ }^{87} \mathrm{Sr}{ }^{86} \mathrm{Sr}-{ }^{143} \mathrm{Nd} /{ }^{144} \mathrm{Nd}$ isotopic ratios. 
Table 2 - Isotopic compositions of Mosquito Formation basalts

\begin{tabular}{|c|c|c|c|c|c|c|c|c|c|c|c|c|}
\hline Sample & $\mathbf{R b}$ & $\mathrm{Sr}$ & ${ }^{87} \mathrm{Sr} /{ }^{86} \mathrm{Sr}$ & $\begin{array}{c}\text { Error } \\
2 \sigma\end{array}$ & $\begin{array}{l}{ }^{87} \mathrm{Sr} /{ }^{86} \mathrm{Sr} \\
(200 \mathrm{Ma})\end{array}$ & $\mathrm{Sm}$ & Nd & ${ }^{147} \mathrm{Sm} /{ }^{144} \mathrm{Nd}$ & ${ }^{143} \mathrm{Nd} /{ }^{144} \mathrm{Nd}$ & $\begin{array}{c}\text { Error } \\
2 \sigma\end{array}$ & $\begin{array}{c}{ }^{143} \mathrm{Nd} / /^{144} \mathrm{Nd} \\
(200 \mathrm{Ma})\end{array}$ & $\begin{array}{c}\varepsilon \mathrm{Nd} \\
(200 \mathrm{Ma})\end{array}$ \\
\hline BP-02 & 24 & 258 & 0.70770 & 0.000049 & 0.70695 & 3.15 & 12.8 & 0.148862 & 0.512444 & 0.000008 & 0.512249 & -2.56 \\
\hline BP-08 & 22 & 275 & 0.70811 & 0.000052 & 0.70746 & 3.40 & 13.4 & 0.153482 & 0.512447 & 0.000007 & 0.512246 & -2.62 \\
\hline BP-19 & 4 & 212 & 0.70337 & 0.000053 & 0.70323 & 4.24 & 14.8 & 0.173296 & 0.512893 & 0.000008 & 0.512666 & 5.57 \\
\hline BP-30 & 1 & 220 & 0.70301 & 0.000039 & 0.70296 & 4.50 & 16.0 & 0.170128 & 0.512885 & 0.000007 & 0.512662 & 5.50 \\
\hline BP-35 & 19 & 369 & 0.70821 & 0.000047 & 0.70780 & 3.25 & 11.4 & 0.172450 & 0.512473 & 0.000008 & 0.512248 & -2.59 \\
\hline BP-39 & 8 & 251 & 0.70781 & 0.000069 & 0.70755 & 2.48 & 10.3 & 0.145646 & 0.512457 & 0.000009 & 0.512266 & -2.23 \\
\hline BP-54 & 38 & 184 & 0.70832 & 0.000047 & 0.70660 & 3.50 & 15.4 & 0.137477 & 0.512427 & 0.000007 & 0.512247 & -2.60 \\
\hline BP-56A & 48 & 829 & 0.70888 & 0.000024 & 0.70841 & 4.21 & 16.4 & 0.155282 & 0.512475 & 0.000007 & 0.512272 & -2.12 \\
\hline BP-61A & 25 & 178 & 0.70559 & 0.000045 & 0.70445 & 2.96 & 13.3 & 0.134624 & 0.512441 & 0.000008 & 0.512265 & -2.26 \\
\hline BP-117 & 21 & 316 & 0.70805 & 0.000059 & 0.70751 & 5.41 & 18.3 & 0.178826 & 0.512866 & 0.000007 & 0.512632 & 4.90 \\
\hline BP-119A & 24 & 173 & 0.70783 & 0.000082 & 0.70668 & 3.50 & 15.0 & 0.141143 & 0.512481 & 0.000007 & 0.512296 & -1.65 \\
\hline BP-121H1 & 32 & 175 & 0.70802 & 0.000049 & 0.70650 & 3.44 & 15.3 & 0.136004 & 0.512435 & 0.000007 & 0.512257 & -2.41 \\
\hline BP-128 & 18 & 242 & 0.70471 & 0.000037 & 0.70409 & 3.42 & 12.7 & 0.162894 & 0.512890 & 0.000006 & 0.512677 & 5.78 \\
\hline BP-129 & 31 & 188 & 0.70851 & 0.000076 & 0.70713 & 3.49 & 14.8 & 0.142642 & 0.512432 & 0.000007 & 0.512245 & -2.65 \\
\hline
\end{tabular}




\subsubsection{Sardinha Formation}

\subsubsection{Petrography}

The Sardinha Formation rocks occur mainly as diabase dykes and sills and as minor basaltic flows. Rocks are mostly porphyritic, greenish to gray-colored diabase (Fig.8a), whereas black aphanitic basalts are less common (Fig.8b). In thin section, there is a range of mineral assemblages. Olivine, augite, plagioclase and $\mathrm{Fe}-\mathrm{Ti}$ oxides (magnetite with exsolved ilmenite) represent the main mineralogical constituents. Volcanic glass, diopside, pigeonite, apatite, pyrite and chalcopyrite may or may not occur as minor phases. Calcite- or zeolite-filled amygdales are rare and appear in fine-grained rocks. Particularly, the four alkaline-trending samples (Fig.2a) comprise diopside, olivine, plagioclase and Fe-Ti oxides with volcanic glass present in two of them.

Sardinha Formation rocks were divided into five petrographic groups, taking into account their mineralogical assemblage and texture: (i) subophitic basalt with devitrified glass and minor alteration, calcite-filled amygdules and fine-grained matrix (Fig.8c, d), (ii) clinopyroxene-plagioclase diabase (Fig.8e), (iii) olivine, clinopyroxene and plagioclase in intergranular texture (Fig.8f), (iv) micro-gabbro with poikilitic diopside including olivine, plagioclase and oxides in a medium-grained matrix (Fig.8g), (v) olivine-diopside porphyritic basalt with fine-grained glassy matrix and calcite amygdules (Fig.8h). Apatite and pyrite appear as minor phases in groups (i) to (iv). Alteration minerals are amphibole, epidote and white mica replacing clinopyroxene (mainly augite) and plagioclase, respectively.

Rare alkali-feldspar/quartz intergrowth characterizes late stage crystallization, mainly on group (i) (Fig.8c). One cumulate olivine gabbro with large crystals (>2 mm) was not considered further on due to pervasive alteration represented by amphibole, epidote, biotite and white mica and also because it is a cumulate rock, not representing the magmatic liquid. 

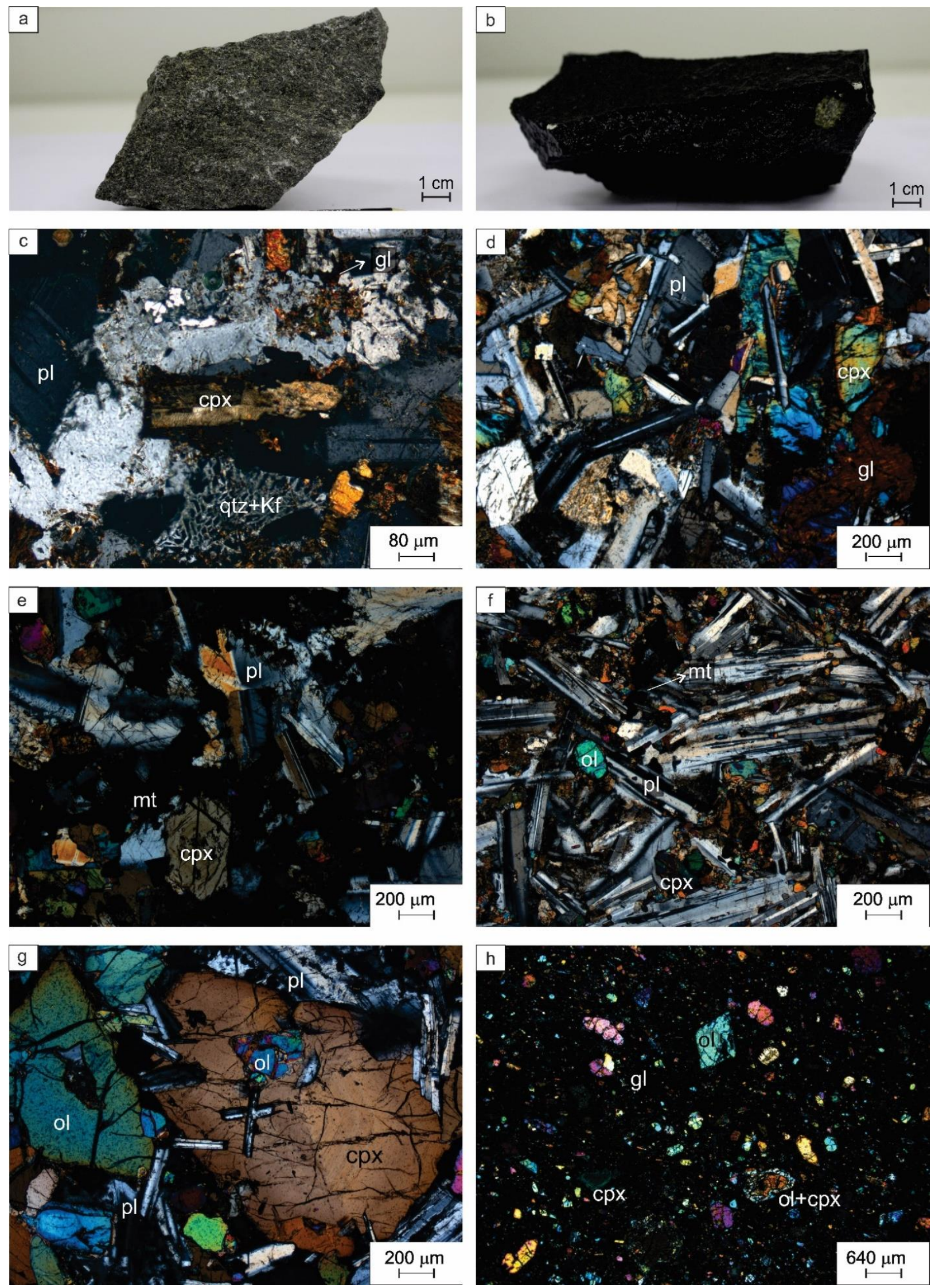


\subsubsection{Mineral chemistry}

Olivine is present in petrographic groups (iii), (iv) and (v). Group (iii) diabases have forsterite content of Fo47-37. Values with a higher content of fayalite are usually observed in phenocryst rims. In groups (iv) and (v) olivine crystals display a large compositional range (i.e., Fo77-43, mainly due to core-rim zonation), with Fo-richer cores (Fo77-64) in comparison to rims (Fo56-43). Olivine is generally included in poikilitic diopside (Fig.8g, h). Olivine phenocrysts in contact with groundmass in general show more evident zoning than the clinopyroxene and display lower Fo contents. Notably, group (v) rocks display more distinctive olivine zonation.

Clinopyroxene analyzes indicated compositions varying from pigeonite to diopside. Groups (i) and (ii) phenocrysts range from diopside to pigeonite in composition, with the intermediate augite composition being the most frequent. Sample DCO-58 displays diopside crystals with homogeneous Mg\# 85-88. The other samples have mainly augite with rare pigeonite crystals, with Mg\# varying from 72 to 62 in augite and from 61 to 54 in pigeonite phenocrysts. Crystals in group (iii) rocks are mainly augite with Mg\# varying from 85 to 69 . They have lower Mg\# in the groundmass augite, whereas phenocrysts display slightly narrower compositional range, from 85 to 76 . Only one pigeonite crystal was analyzed in group (iii) rocks and have $\mathrm{Mg \#}$ of 64 . Clinopyroxene in groups (iv) and (v) rocks is distinct from the other Sardinha Formation groups in the sense that only diopside is present, commonly with high Wo content (Wo49-44). Mg\# varies from 92 to 75. Lower Mg\# values generally occur towards the phenocryst rims. Augite-pigeonite geothermometer (relative to 0.2-0.3 GPa) was applied to two-pyroxene rocks of groups (ii) and (iii). Results yield equilibrium temperature around $1050 \pm 30^{\circ} \mathrm{C}$ for group (iii) tholeiites and $1090 \pm 20^{\circ} \mathrm{C}$, for group (ii) rocks.

Figure 8 - General aspects of the Sardinha Formation. a) Diabase dyke hand sample of the Sardinha Formation; b) Typical alkali-basalt hand sample of the Sardinha Formation, showing an aggregate of olivine crystals; c) Group i) Sardinha basalt (DCO-46) with highlighted mineral assemblage, note zoned clinopyroxene and late stage quartz/Kfeldspar intergrowth (high-Ti Sardinha Formation sample). d) Group (i) Sardinha basalt with similar mineral assemblage shown on figure $c$ showing less alteration, greater glass occurrence and sub-ophitic texture (low-Ti Sardinha Formation sample). e) Group (ii) Sardinha basalt, showing mineral assemblage with zoned clinopyroxene crystal and lack of glass material (high-Ti Sardinha Formation sample). f) Group (iii) olivine basalt (low-Ti Sardinha Formation sample). g) Group (iv) Sardinha Formation diabase/gabbro with well developed euhedral porphyritic clinopyroxene crystal encompassing olivine and plagioclase crystals. h) Olivine alkali-basalt, euhedral olivine and diopside crystals immersed in fine grained aphanitic matrix, note olivine with clinopyroxene rim. Micro petrographic photos were taken with crossed polarizers. OI = olivine, $\mathrm{pl}=$ plagioclase, $c p x=$ clinopyroxene, $m t=$ magnetite $(F e-T i$ oxide $), g l=$ volcanic glass, qtz = quartz, $K-f=K$ feldspar. 
Plagioclase composition of groups (i) and (ii) range from andesine to labradorite (An57-44Ab43-52Or 1.9-4.2). Group (iii) plagioclase phenocrysts are mainly labradorite (An60${ }_{50} \mathrm{Ab}_{40-48} \mathrm{Or}_{1.2-2.8}$. One plagioclase with olivine inclusions yielded bytownite composition of $\mathrm{An}_{84} \mathrm{Ab}_{16} \mathrm{Or} 0.4$ indicating Ca-richer phases in early crystallization. Groups (iv) and (v) phenocrysts are zoned with compositions ranging from An-rich cores to An-poor rims (labradorite $A n_{66-58} \mathrm{Ab}_{36-41} \mathrm{Or}_{1.0-1.5}$ to andesine-oligoclase $\mathrm{An}_{49-27} \mathrm{Ab}_{50-67} \mathrm{Or}_{1.2-6.5)}$. An-poor phases are more frequent than on the other groups. Overall, phenocrysts and groundmass of all groups suggest Fe-enrichment and Ca-depletion in magma before matrix crystallization. However, groups (iv) and (v) present distinct mineralogical compositions and mineral chemistry, enough to stand out as very different rocks in comparison to the other Sardinha Formation types.

\subsubsection{Major and trace elements}

Sardinha Formation rocks were divided into three groups (Fig.6) taking into account their major element contents (particularly $\mathrm{SiO}_{2}$ and $\mathrm{TiO}_{2}$ wt.\%) and their association with petrography and mineral chemistry. The groups are: (i) high- $\mathrm{Ti}\left(\mathrm{SiO}_{2}>48.0\right.$ wt.\% and $\mathrm{TiO}_{2}$ $>2.0$ wt.\%), (ii) low-Ti $\left(\mathrm{SiO}_{2}>48.0\right.$ wt.\% and $\mathrm{TiO}_{2}<2.0$ wt.\%) and (iii) Alkali-basalt $\left(\mathrm{SiO}_{2}\right.$ $<48 \%$ wt.\% and $\mathrm{TiO}_{2} \geq 2.0$ wt.\%). They display differences in overall major element compositions as shown in Fig.9. Concerning their mineralogical characteristics, one sample from group (i) (Fig.8c) and all group (ii) rocks characterize the high-Ti group. Groups (i) and (iii) basalts represent the low-Ti group and groups (iv) and (v) constitute the Alkali-basalt group. Representative samples of all groups are shown in Table 4.

Two subgroups of tholeiites represent the low-Ti group, one quartz/hypersthenenormative (Fig.9d) and one olivine/hypersthene-normative (Fig.9f) group. In general, lowTi rocks have high contents of $\mathrm{MgO}, \mathrm{CaO}$ and $\mathrm{Mg} \#$ (Fig.9a, $\mathrm{f}$, i) with $\mathrm{Cr}+\mathrm{Ni}$ contents (Fig.9j) varying from 385 to $481 \mathrm{ppm}$ in the olivine/hypersthene-normative rocks and from 80 to $146 \mathrm{ppm}$ in the quartz/hypersthene-normative basalts. The low-Ti group also have the lowest $\mathrm{K}_{2} \mathrm{O}$ and $\mathrm{P}_{2} \mathrm{O}_{5}$ contents in the Sardinha Formation rocks (Fig.9d, g).

High-Ti samples comprise quartz/hypersthene-normative basalts (Fig.8e) with homogeneous values of major and trace elements (Figs. 9 and 10). Only one sample 
Table 3 - Compositions of whole-rock samples from the Sardinha Formation.

\begin{tabular}{|c|c|c|c|c|c|c|c|c|}
\hline $\begin{array}{c}\text { Sample } \\
\text { Group }\end{array}$ & $\begin{array}{c}\text { DCO } 41 \\
\text { Low-Ti } \\
\text { qtz }\end{array}$ & $\begin{array}{l}\text { DCO } 45 \\
\text { Low-Ti } \\
\text { qtz }\end{array}$ & $\begin{array}{c}\text { DCO } 47 \\
\text { Low-Ti } \\
\text { ol }\end{array}$ & $\begin{array}{c}\text { DCO } 49 \\
\text { Low-Ti } \\
\text { ol }\end{array}$ & $\begin{array}{c}\text { DCO } 50 \\
\text { Low-Ti } \\
\text { ol }\end{array}$ & $\begin{array}{c}\text { DCO } 54 \\
\text { Low-Ti } \\
\text { ol }\end{array}$ & $\begin{array}{l}\text { DCO } 46 \\
\text { High-Ti }\end{array}$ & $\begin{array}{l}\text { DCO } 37 \\
\text { High-Ti }\end{array}$ \\
\hline $\mathrm{SiO}_{2}$ (wt.\%) & 53.2 & 52.6 & 50.5 & 50.1 & 48.4 & 51.3 & 55.7 & 51.7 \\
\hline $\mathrm{TiO}_{2}$ & 1.68 & 1.35 & 1.55 & 1.97 & 1.51 & 1.96 & 2.37 & 3.21 \\
\hline $\mathrm{Al}_{2} \mathrm{O}_{3}$ & 12.95 & 13.4 & 14.8 & 14.75 & 15.1 & 14.8 & 11.4 & 12.7 \\
\hline $\mathrm{Fe}^{2} \mathrm{O}^{*}$ & 14.55 & 12.4 & 11.7 & 11.8 & 10.6 & 11.25 & 15.3 & 13.95 \\
\hline MnO & 0.25 & 0.19 & 0.15 & 0.15 & 0.14 & 0.14 & 0.22 & 0.19 \\
\hline MgO & 5.37 & 6.44 & 7.83 & 8.21 & 6.63 & 6.9 & 1.84 & 3.98 \\
\hline $\mathrm{CaO}$ & 9.14 & 10.25 & 8.96 & 9.07 & 9.37 & 8.27 & 6.35 & 7.39 \\
\hline $\mathrm{Na}_{2} \mathrm{O}$ & 2.38 & 2.2 & 3.16 & 3.18 & 3.31 & 3.44 & 2.86 & 2.72 \\
\hline $\mathrm{K}_{2} \mathrm{O}$ & 0.8 & 0.51 & 0.55 & 0.47 & 0.77 & 0.72 & 1.42 & 1.77 \\
\hline $\mathrm{P}_{2} \mathrm{O}_{5}$ & 0.17 & 0.13 & 0.2 & 0.21 & 0.31 & 0.25 & 0.37 & 0.67 \\
\hline LOI & 1.12 & 0.75 & 0.12 & -0.25 & 2.79 & 0.47 & 1.08 & 1.43 \\
\hline Total & 101.61 & 100.22 & 99.52 & 99.66 & 98.93 & 99.5 & 98.91 & 99.71 \\
\hline Sc (ppm) & 38 & 39 & 20 & 20 & 22 & 17 & 31 & 24 \\
\hline V & 486 & 394 & 179 & 189 & 187 & 168 & 100 & 349 \\
\hline $\mathrm{Ba}$ & 213 & 171 & 101.5 & 86.2 & 277 & 134 & 416 & 563 \\
\hline $\mathrm{Sr}$ & 208 & 208 & 328 & 377 & 550 & 398 & 232 & 629 \\
\hline $\mathbf{Y}$ & 30.9 & 24.5 & 16.6 & 17.2 & 18.7 & 16.9 & 58.2 & 40.7 \\
\hline $\mathrm{Zr}$ & 134 & 105 & 90 & 94 & 130 & 111 & 279 & 313 \\
\hline $\mathrm{Cr}$ & 30 & 70 & 250 & 260 & 280 & 220 & 10 & 50 \\
\hline Co & 43 & 46 & 51 & 49 & 42 & 45 & 32 & 34 \\
\hline $\mathbf{N i}$ & 50 & 76 & 213 & 221 & 104 & 165 & $<1$ & 29 \\
\hline $\mathrm{Cu}$ & 189 & 152 & 78 & 70 & 52 & 64 & 441 & 90 \\
\hline $\mathrm{Zn}$ & 212 & 115 & 131 & 123 & 105 & 128 & 171 & 163 \\
\hline Ga & 23.5 & 21.7 & 22.9 & 22.5 & 22.7 & 24.1 & 27.2 & 29.9 \\
\hline $\mathbf{R b}$ & 25.7 & 16.4 & 7.9 & 6.5 & 11.9 & 11.4 & 48.7 & 41.3 \\
\hline $\mathrm{Nb}$ & 9.5 & 6.7 & 11.9 & 12.4 & 17.8 & 16.6 & 19.3 & 32.4 \\
\hline Mo & $<1$ & $<1$ & $<1$ & 1 & 1 & $<1$ & $<1$ & $<1$ \\
\hline Cs & 1.25 & 0.88 & 0.17 & 0.45 & 0.74 & 0.42 & 2.64 & 0.67 \\
\hline La & 15.6 & 11.5 & 9.7 & 8.6 & 20.3 & 11.4 & 32 & 44.3 \\
\hline $\mathrm{Ce}$ & 34.7 & 25.9 & 19.6 & 19 & 40.3 & 23.4 & 71.9 & 99.1 \\
\hline $\mathrm{Pr}$ & 4.56 & 3.34 & 2.67 & 2.53 & 4.85 & 3.01 & 9.21 & 12.5 \\
\hline Nd & 19.5 & 14.2 & 11.3 & 11 & 19 & 13 & 37.3 & 51.5 \\
\hline Sm & 5.12 & 3.7 & 3.21 & 3.32 & 4.34 & 3.95 & 9.94 & 11.65 \\
\hline Eu & 1.8 & 1.38 & 1.19 & 1.45 & 1.61 & 1.41 & 2.9 & 3.58 \\
\hline Gd & 6.65 & 5.06 & 4.25 & 4.24 & 4.93 & 4.49 & 11.3 & 11.8 \\
\hline Tb & 0.95 & 0.79 & 0.66 & 0.75 & 0.77 & 0.62 & 1.75 & 1.62 \\
\hline Dy & 6.01 & 4.78 & 3.64 & 3.69 & 3.9 & 3.79 & 10.1 & 8.95 \\
\hline Ho & 1.22 & 0.97 & 0.67 & 0.67 & 0.74 & 0.63 & 2.14 & 1.62 \\
\hline Er & 3.53 & 2.64 & 1.7 & 1.81 & 2.01 & 1.55 & 6.29 & 4.23 \\
\hline Tm & 0.49 & 0.4 & 0.23 & 0.22 & 0.27 & 0.22 & 0.94 & 0.55 \\
\hline Yb & 3.29 & 2.39 & 1.42 & 1.34 & 1.66 & 1.19 & 5.72 & 3.39 \\
\hline Lu & 0.46 & 0.37 & 0.19 & 0.21 & 0.24 & 0.19 & 0.81 & 0.47 \\
\hline $\mathrm{Hf}$ & 3.9 & 2.9 & 2.5 & 2.5 & 3 & 2.9 & 7.7 & 8.2 \\
\hline Ta & 0.6 & 0.5 & 0.7 & 0.8 & 1 & 0.9 & 1.3 & 2 \\
\hline $\mathrm{Pb}$ & 6 & 9 & $<2$ & 5 & 4 & $<2$ & 14 & 12 \\
\hline Th & 2.97 & 2.1 & 1.09 & 0.97 & 1.93 & 1.5 & 5.51 & 5.29 \\
\hline
\end{tabular}

Note: $q t z$ = quartz/hypersthene normative ol = olivine/hypersthene normative 
Table 3 - Continued

\begin{tabular}{|c|c|c|c|c|c|c|c|c|}
\hline $\begin{array}{l}\text { Sample } \\
\text { Group }\end{array}$ & $\begin{array}{l}\text { DCO } 39 \\
\text { High-Ti }\end{array}$ & $\begin{array}{l}\text { DCO } 43 \\
\text { High-Ti }\end{array}$ & $\begin{array}{l}\text { DCO } 48 \\
\text { High-Ti }\end{array}$ & $\begin{array}{l}\text { DCO } 51 \\
\text { High-Ti }\end{array}$ & $\begin{array}{l}\text { DCO } 55 \\
\text { High-Ti }\end{array}$ & $\begin{array}{l}\text { DCO } 56 \\
\text { High-Ti }\end{array}$ & $\begin{array}{l}\text { DCO } 57 \\
\text { High-Ti }\end{array}$ & $\begin{array}{l}\text { DCO } 58 \\
\text { High-Ti }\end{array}$ \\
\hline $\mathrm{SiO}_{2}$ (wt.\%) & 51.4 & 52.2 & 49.7 & 50.6 & 51.1 & 52.4 & 50.6 & 50.4 \\
\hline $\mathrm{TiO}_{2}$ & 3.4 & 3.32 & 3.33 & 3.35 & 3.19 & 3.35 & 3.08 & 3.1 \\
\hline $\mathrm{Al}_{2} \mathrm{O}_{3}$ & 12.35 & 12.6 & 12.5 & 12.35 & 12.85 & 12.35 & 11.95 & 12.65 \\
\hline $\mathrm{Fe}^{2 \mathrm{O} 3}{ }^{\star}$ & 15 & 15.1 & 15.1 & 14.8 & 14.75 & 15.8 & 14 & 14.85 \\
\hline MnO & 0.2 & 0.21 & 0.2 & 0.21 & 0.19 & 0.21 & 0.19 & 0.19 \\
\hline MgO & 3.88 & 3.7 & 4.49 & 3.94 & 4.38 & 3.99 & 4.73 & 4.31 \\
\hline $\mathrm{CaO}$ & 7.12 & 7.51 & 7.89 & 7.41 & 7.83 & 7.53 & 8.12 & 7.38 \\
\hline $\mathrm{Na}_{2} \mathrm{O}$ & 2.61 & 2.68 & 2.76 & 2.57 & 2.87 & 2.67 & 2.47 & 3.01 \\
\hline $\mathrm{K}_{2} \mathrm{O}$ & 1.94 & 1.8 & 1.4 & 1.66 & 1.46 & 1.74 & 1.61 & 1.53 \\
\hline $\mathrm{P}_{2} \mathrm{O}_{5}$ & 0.52 & 0.53 & 0.43 & 0.49 & 0.46 & 0.54 & 0.6 & 0.45 \\
\hline LOI & 0.9 & 0.8 & 2.02 & 1.15 & 2.12 & 1.17 & 1.34 & 2.19 \\
\hline Total & 99.32 & 100.45 & 99.82 & 98.53 & 101.2 & 101.75 & 98.69 & 100.06 \\
\hline Sc (ppm) & 28 & 28 & 29 & 28 & 28 & 29 & 27 & 27 \\
\hline V & 445 & 433 & 504 & 458 & 480 & 463 & 372 & 467 \\
\hline $\mathrm{Ba}$ & 622 & 575 & 446 & 526 & 483 & 560 & 520 & 501 \\
\hline $\mathrm{Sr}$ & 530 & 545 & 557 & 520 & 582 & 506 & 570 & 567 \\
\hline $\mathbf{Y}$ & 42.2 & 43.1 & 36.1 & 41.1 & 37.1 & 40.9 & 37.9 & 35 \\
\hline $\mathrm{Zr}$ & 306 & 308 & 251 & 296 & 261 & 287 & 280 & 249 \\
\hline $\mathrm{Cr}$ & 10 & 10 & 40 & 10 & 40 & 10 & 120 & 40 \\
\hline Co & 36 & 37 & 43 & 37 & 42 & 38 & 38 & 37 \\
\hline $\mathrm{Ni}$ & 30 & 25 & 41 & 32 & 39 & 31 & 50 & 42 \\
\hline $\mathrm{Cu}$ & 217 & 223 & 126 & 228 & 142 & 237 & 106 & 127 \\
\hline $\mathrm{Zn}$ & 152 & 190 & 161 & 158 & 147 & 166 & 176 & 204 \\
\hline Ga & 28.6 & 28.8 & 29.1 & 28.6 & 29.8 & 28.2 & 27.9 & 27.1 \\
\hline $\mathbf{R b}$ & 53.1 & 48.1 & 32 & 45.4 & 32.7 & 42.8 & 36.6 & 37.8 \\
\hline $\mathrm{Nb}$ & 29.6 & 29.9 & 22.8 & 28.5 & 22.8 & 28.4 & 25.9 & 21.8 \\
\hline Mo & 2 & $<1$ & $<1$ & 1 & $<1$ & $<1$ & 1 & $<1$ \\
\hline Cs & 1.49 & 3.23 & 0.39 & 1.33 & 0.35 & 1.34 & 0.57 & 0.69 \\
\hline La & 44.2 & 46.4 & 34.8 & 42.7 & 36.4 & 43.9 & 40.6 & 36 \\
\hline $\mathrm{Ce}$ & 98.1 & 98.9 & 77.8 & 93.8 & 82.1 & 94.6 & 91.8 & 79.1 \\
\hline $\mathrm{Pr}$ & 12.15 & 12.6 & 9.88 & 11.5 & 10.1 & 11.75 & 11.55 & 10.25 \\
\hline $\mathrm{Nd}$ & 48.4 & 50.1 & 40.9 & 47.7 & 41.9 & 47.5 & 47.8 & 40.6 \\
\hline $\mathrm{Sm}$ & 10.2 & 10.75 & 8.72 & 10.5 & 9.56 & 10.4 & 11.05 & 9.42 \\
\hline $\mathrm{Eu}$ & 3.19 & 3.47 & 2.89 & 2.92 & 2.95 & 3.06 & 3.02 & 2.88 \\
\hline Gd & 10.95 & 11 & 9.51 & 10.8 & 9.82 & 10.95 & 10.4 & 9.47 \\
\hline Tb & 1.61 & 1.67 & 1.43 & 1.59 & 1.43 & 1.53 & 1.5 & 1.34 \\
\hline Dy & 8.37 & 8.47 & 7.86 & 8.27 & 7.83 & 8.52 & 7.93 & 7.9 \\
\hline Ho & 1.59 & 1.56 & 1.42 & 1.61 & 1.4 & 1.54 & 1.39 & 1.39 \\
\hline Er & 4.29 & 4.7 & 3.93 & 4.06 & 4.11 & 4.32 & 3.95 & 3.62 \\
\hline Tm & 0.56 & 0.61 & 0.48 & 0.56 & 0.54 & 0.58 & 0.49 & 0.47 \\
\hline $\mathrm{Yb}$ & 3.8 & 3.75 & 3.19 & 3.62 & 3.49 & 3.78 & 3.11 & 3.12 \\
\hline Lu & 0.53 & 0.53 & 0.43 & 0.52 & 0.5 & 0.51 & 0.46 & 0.45 \\
\hline Hf & 7.7 & 7.8 & 6.6 & 7.5 & 6.7 & 7.6 & 7.2 & 6.4 \\
\hline Ta & 1.9 & 1.9 & 1.4 & 1.8 & 1.5 & 1.8 & 1.5 & 1.3 \\
\hline $\mathrm{Pb}$ & 11 & 6 & 7 & 14 & 10 & 7 & 8 & 6 \\
\hline Th & 5.69 & 5.63 & 4.05 & 5.09 & 4.49 & 5.35 & 4.28 & 4.22 \\
\hline
\end{tabular}


Table 3 - Continued

\begin{tabular}{|c|c|c|c|c|}
\hline $\begin{array}{l}\text { Sample } \\
\text { Group }\end{array}$ & $\begin{array}{c}\text { DCO } 36 \\
\text { Alkali-basalt }\end{array}$ & $\begin{array}{c}\text { DCO } 40 \\
\text { Alkali-basalt }\end{array}$ & $\begin{array}{c}\text { DCO } 52 \\
\text { Alkali-basalt }\end{array}$ & $\begin{array}{c}\text { DCO } 53 \\
\text { Alkali-basalt }\end{array}$ \\
\hline $\mathrm{SiO}_{2}$ (wt.\%) & 46.1 & 47.3 & 43.8 & 47.1 \\
\hline $\mathrm{TiO}_{2}$ & 2.00 & 2.08 & 2.82 & 2.04 \\
\hline $\mathrm{Al}_{2} \mathrm{O}_{3}$ & 16.65 & 13.30 & 11.80 & 16.55 \\
\hline $\mathrm{Fe}^{203^{*}}$ & 10.75 & 10.75 & 12.15 & 11.20 \\
\hline MnO & 0.16 & 0.15 & 0.17 & 0.16 \\
\hline $\mathrm{MgO}$ & 5.56 & 9.61 & 10.10 & 5.64 \\
\hline $\mathrm{CaO}$ & 9.88 & 9.94 & 10.70 & 9.75 \\
\hline $\mathrm{Na}_{2} \mathrm{O}$ & 4.25 & 2.76 & 2.95 & 4.32 \\
\hline $\mathrm{K}_{2} \mathrm{O}$ & 1.50 & 1.46 & 1.61 & 1.49 \\
\hline $\mathrm{P}_{2} \mathrm{O}_{5}$ & 0.70 & 0.42 & 0.70 & 0.67 \\
\hline LOI & 0.57 & 1.83 & 1.79 & 0.64 \\
\hline Total & 98.12 & 99.60 & 98.59 & 99.56 \\
\hline Sc (ppm) & 20 & 21 & 20 & 19 \\
\hline v v & 212 & 227 & 252 & 219 \\
\hline $\mathrm{Ba}$ & 510 & 487 & 556 & 460 \\
\hline $\mathrm{Sr}$ & 901 & 690 & 919 & 933 \\
\hline $\mathbf{Y}$ & 25.6 & 21.9 & 24.3 & 24.9 \\
\hline $\mathbf{Z r}$ & 210 & 168 & 271 & 202 \\
\hline $\mathrm{Cr}$ & 70 & 400 & 310 & 70 \\
\hline Co & 35 & 47 & 50 & 36 \\
\hline $\mathrm{Ni}$ & 54 & 236 & 203 & 55 \\
\hline $\mathrm{Cu}$ & 59 & 54 & 50 & 59 \\
\hline $\mathbf{Z n}$ & 92 & 144 & 125 & 131 \\
\hline $\mathrm{Ga}$ & 22.9 & 23.7 & 23.6 & 26.6 \\
\hline $\mathbf{R b}$ & 24 & 44.8 & 39.5 & 22.6 \\
\hline $\mathrm{Nb}$ & 43.3 & 43 & 66.9 & 45.9 \\
\hline Mo & 2 & 1 & 2 & 1 \\
\hline Cs & 0.31 & 0.73 & 0.51 & 0.34 \\
\hline La & 41.7 & 33.3 & 54.7 & 40.4 \\
\hline $\mathrm{Ce}$ & 79.6 & 66.1 & 107.5 & 78.1 \\
\hline Pr & 8.74 & 7.97 & 12.3 & 9.06 \\
\hline Nd & 36 & 30.9 & 47.4 & 33.7 \\
\hline Sm & 7.33 & 6.88 & 9.35 & 6.37 \\
\hline Eu & 2.36 & 2.2 & 2.99 & 2.34 \\
\hline Gd & 6.83 & 6.89 & 8.55 & 7.25 \\
\hline Tb & 0.92 & 0.92 & 1.11 & 1.07 \\
\hline Dy & 5.43 & 5.23 & 5.7 & 5.82 \\
\hline Ho & 0.86 & 0.91 & 0.95 & 1 \\
\hline $\mathrm{Er}$ & 2.36 & 2.14 & 2.35 & 2.61 \\
\hline Tm & 0.34 & 0.28 & 0.32 & 0.3 \\
\hline $\mathrm{Yb}$ & 1.94 & 1.78 & 1.62 & 2.07 \\
\hline Lu & 0.26 & 0.23 & 0.23 & 0.31 \\
\hline $\mathrm{Hf}$ & 4.9 & 4.2 & 6.5 & 4.6 \\
\hline $\mathrm{Ta}$ & 2.2 & 2.6 & 4.3 & 2.5 \\
\hline $\mathbf{P b}$ & $<2$ & 3 & 5 & 6 \\
\hline Th & 4.28 & 4.19 & 5.93 & 3.72 \\
\hline
\end{tabular}

(Fig.8c; DCO-46) yielded divergent compositions in major oxides (Fig.9), and also displays the most evolved composition of the Sardinha Formation rocks, with the highest $\mathrm{SiO}_{2}$ content (over 55\% wt.) and lowest $\mathrm{Mg \# ,} \mathrm{MgO}, \mathrm{CaO}$ and $\mathrm{Cr}+\mathrm{Ni}$ values (Fig.9a, f, i, j). 
The Alkali-basalt group displays the lowest $\mathrm{SiO}_{2}$ content of the Sardinha Formation rocks. These are the only samples that plot on the alkaline field of the TAS diagram (Fig.2), with lower $\mathrm{SiO}_{2}$ contents and higher values of alkalis (Fig.9d, h). Overall, samples from this group display a broad compositional variation (Fig.9).

Multi-element diagrams for the three groups, normalized to PM (Fig.10a, b) and $\mathrm{CH}$ (Fig.10c, d), display significant differences. Low-Ti rocks display lower values of LILE and HFSE. The low-Ti quartz/hypersthene-normalized samples (shown in Fig.10a as DCO-41 and DCO-45) display negative $\mathrm{Nb}, \mathrm{Ta}$ and $\mathrm{P}$ with positive $\mathrm{Pb}$ anomalies with slightly enriched compositions of HFSE when compared to the other low-Ti tholeiites. It is interesting to note that these basalts are similar to Mosquito Formation compositions, but with distinctive positive anomaly of $\mathrm{Pb}$ (as all Sardinha Formation rocks). Low-Ti quartz/hypersthene-normative rocks display enrichment in HREE/LREE (i.e., average $\mathrm{LacH} / \mathrm{YbCH}_{\mathrm{C}}=3.2$ ) in comparison to low-Ti olivine/hypersthene-normative basalts (i.e., average $\mathrm{LacH} / \mathrm{YbcH}=6$; Fig.10c).

High-Ti basalts have comparatively high LILE and LREE contents, with $\mathrm{Nb}-\mathrm{Ta}$ negative anomalies ( $\mathrm{LaCH}_{\mathrm{H}} / \mathrm{Yb}_{\mathrm{CH}}=7.1-8.9$; Fig.10b, d). Sample DCO-46 (Fig.10b) display a negative $\mathrm{Sr}$ anomaly, with higher contents of HFSE and HREE and lower $\mathrm{LacH} / \mathrm{YbcH}$ ratio $(\mathrm{LacH} / \mathrm{YbcH}=3.8$; Fig.10b, d). Finally, the Alkali-basalt group shows homogeneous trace element compositions with positive $\mathrm{Nb}-\mathrm{Ta}, \mathrm{P}$ anomalies. Sample DCO-52 (Fig.8h) is distinct as it has higher contents of LILE and $\mathrm{TiO}_{2}$ when compared to other Alkali-basalt rocks (Fig. 10a).

\subsubsection{Sr-Nd isotopes}

$\mathrm{Nd}-\mathrm{Sr}$ isotopic data of the Sardinha Formation are shown in Table 4 and Fig.11. Sr and $\mathrm{Nd}$ isotope ratios were corrected to $130 \mathrm{Ma}$. 
Table 4 - Isotopic composition of Sardinha Formation basalts.

\begin{tabular}{|c|c|c|c|c|c|c|c|c|c|c|c|c|c|}
\hline Sample & $\mathbf{R b}$ & $\mathrm{Sr}$ & ${ }^{87} \mathrm{Sr} /{ }^{86} \mathrm{Sr}$ & $\begin{array}{c}\text { Error } \\
2 \sigma\end{array}$ & $\begin{array}{l}{ }^{87} \mathrm{Sr} /{ }^{86} \mathrm{Sr} \\
(130 \mathrm{Ma})\end{array}$ & Sm & Nd & ${ }^{147} \mathrm{Sm} /{ }^{144} \mathrm{Nd}$ & ${ }^{143} \mathrm{Nd} /{ }^{144} \mathrm{Nd}$ & $\begin{array}{c}\text { Error } \\
2 \sigma\end{array}$ & $\begin{array}{c}{ }^{143} \mathrm{Nd} /{ }^{144} \mathrm{Nd} \\
(130 \mathrm{Ma})\end{array}$ & $\begin{array}{c}\varepsilon N d \\
(130 \mathrm{Ma})\end{array}$ & $\begin{array}{l}\text { TDM } \\
\text { (Ga) }\end{array}$ \\
\hline DCO-37 & 41.3 & 629 & 0.70321 & 0.00001 & 0.702859 & 12.416 & 58.044 & 0.1293 & 0.512485 & 0.000002 & 0.512375 & -1.87 & 1.01 \\
\hline DCO-39 & 53.1 & 530 & 0.70658 & 0.00001 & 0.706044 & 11.135 & 52.459 & 0.1283 & 0.512451 & 0.000002 & 0.512342 & -2.52 & 1.05 \\
\hline DCO-40 & 44.8 & 690 & 0.70403 & 0.00001 & 0.703683 & 7.201 & 34.161 & 0.1274 & 0.512528 & 0.000003 & 0.512420 & -1.00 & 0.91 \\
\hline DCO-41 & na. & na. & na. & na. & na. & 5.628 & 22.718 & 0.1497 & 0.512454 & 0.000002 & 0.512453 & -0.35 & 1.1 \\
\hline DCO-43 & 48.1 & 545 & 0.70384 & 0.00001 & 0.703368 & 11.593 & 54.836 & 0.1278 & 0.512577 & 0.000002 & 0.512345 & -2.45 & 1.04 \\
\hline DCO-45 & 16.4 & 208 & 0.70657 & 0.00001 & 0.706149 & 4.06 & 15.745 & 0.1559 & 0.512588 & 0.000005 & 0.512444 & -0.51 & 1.22 \\
\hline DCO-46 & 48.7 & 232 & 0.70603 & 0.00001 & 0.704908 & 10.492 & 41.252 & 0.1537 & 0.512481 & 0.000005 & 0.512457 & -0.26 & 1.15 \\
\hline DCO-48 & 32 & 557 & 0.70683 & 0.00001 & 0.706523 & 9.917 & 45.693 & 0.1312 & 0.512936 & 0.000002 & 0.512369 & -1.98 & 1.03 \\
\hline DCO-50 & 11.9 & 550 & 0.70568 & 0.00001 & 0.705564 & 4.66 & 20.97 & 0.1343 & 0.512298 & 0.000004 & 0.512184 & -5.60 & 1.42 \\
\hline DCO-51 & 45.4 & 520 & 0.70717 & 0.00001 & 0.706703 & 10.956 & 51.6 & 0.1283 & 0.512443 & 0.000001 & 0.512334 & -2.67 & 1.07 \\
\hline DCO-52 & 39.5 & 919 & 0.70512 & 0.00001 & 0.704890 & 9.776 & 50.635 & 0.1167 & 0.51277 & 0.000003 & 0.512671 & 3.90 & 0.45 \\
\hline DCO-53 & na. & na. & na. & na. & na. & 7.561 & 38.163 & 0.1198 & 0.512834 & 0.000003 & 0.512344 & -2.47 & 0.97 \\
\hline DCO-55 & 32.7 & 582 & 0.70546 & 0.00001 & 0.705160 & 10.012 & 46.099 & 0.1313 & 0.512476 & 0.000003 & 0.512364 & -2.08 & 1.04 \\
\hline DCO-56 & 42.8 & 506 & 0.7064 & 0.00001 & 0.705948 & 10.896 & 51.418 & 0.1281 & 0.512454 & 0.000002 & 0.512345 & -2.45 & 1.05 \\
\hline
\end{tabular}



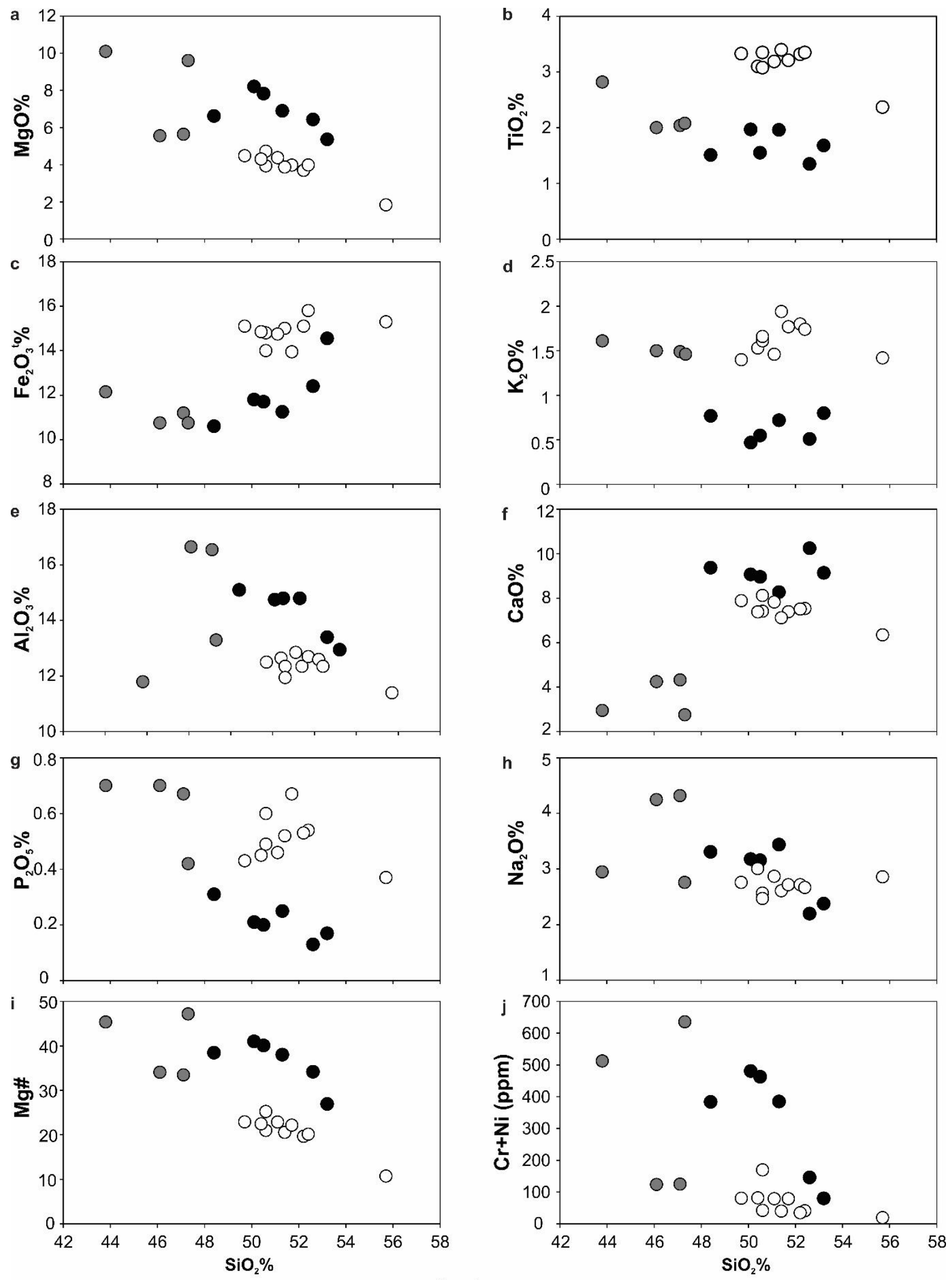

Figure 9 - Major elements versus silica variation diagrams for Sardinha Formation rocks. High-Ti, low-Ti and alkalibasalt groups display small variation within their respective data clusters. 

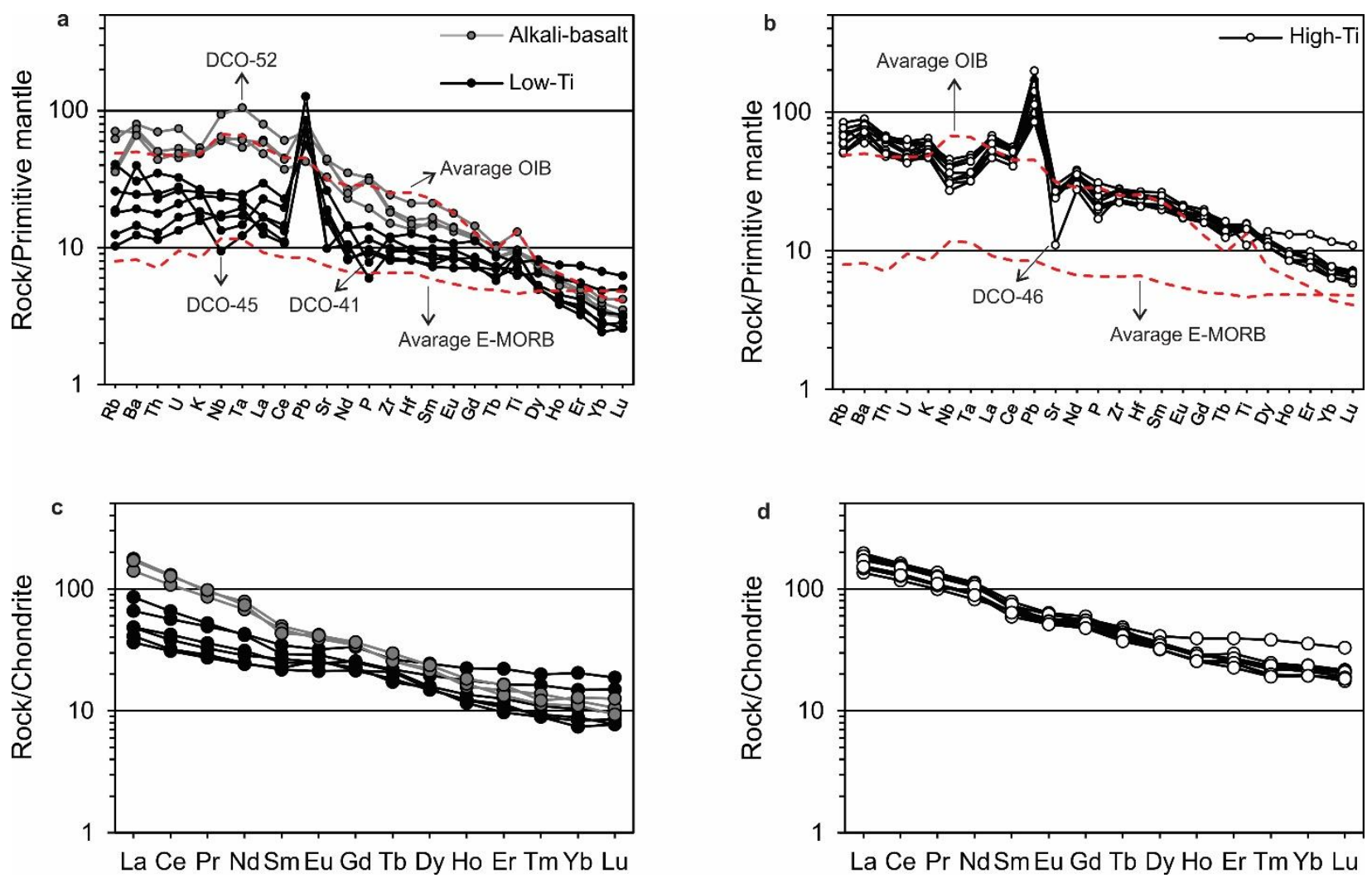

Figure 10 - Multi-element diagrams for the Sardinha Formation basalts (see text for information about highlighted samples). Primitive mantle normalizing values, OIB and MORB compositions after Sun and McDonough (1989), chondritic normalizing values after McDonough and Sun (1995); a) Primitive mantle normalized diagram for low-Ti and alkali-basalt of the Sardinha Formation. b) Primitive mantle normalized diagram for high-Ti Sardinha basalts. c) Chondrite normalized diagram for the low-Ti and alkali-basalts. d) Chondrite normalized diagram for the high-Ti Sardinha Formation rocks.

The low- $\mathrm{Ti}$ quartz/hypersthene-normative tholeiites yielded two initial ${ }^{143} \mathrm{Nd} /{ }^{144} \mathrm{Nd}(130 \mathrm{Ma})$ isotopic values of 0.512453 and $0.512444(\varepsilon \mathrm{Nd}$ of -0.35 and -0.51 , respectively), with TDM model ages of 1.1 and $1.2 \mathrm{Ga}$. One initial ${ }^{87} \mathrm{Sr} /{ }^{86} \mathrm{Sr}(130 \mathrm{Ma})$ ratio is 0.70657. One analyzed low- $\mathrm{Ti}$ olivine/hypersthene-normative sample displayed ${ }^{143} \mathrm{Nd} /{ }^{144} \mathrm{Nd}(130 \mathrm{Ma})$ isotopic ratio of $0.512184(\varepsilon \mathrm{Nd}$ of -5.6$),{ }^{87} \mathrm{Sr} /{ }^{86} \mathrm{Sr}(130 \mathrm{Ma})$ value of 0.70512 and the oldest TDM age (1.42 Ga) of the Sardinha Formation rocks (Fig.11).

The unusual DCO-46 high-Ti sample yielded ${ }^{143} \mathrm{Nd} /{ }^{144} \mathrm{Nd}(130 \mathrm{Ma})$ ratio of 0.512457 , $\varepsilon \mathrm{Nd}$ of -0.26 and TDM model age of $1.15 \mathrm{Ga}$, very similar to low-Ti quartz/hypersthenenormative rocks. ${ }^{87} \mathrm{Sr} /{ }^{86} \mathrm{Sr}_{(130 \mathrm{Ma})}$ also yielded high initial $\mathrm{Sr}$ isotopic ratio $\left({ }^{87} \mathrm{Sr} /{ }^{86} \mathrm{Sr}_{(130 \mathrm{Ma})}\right.$ of 0.70603$)$. The remaining high-Ti samples showed very homogeneous ${ }^{143} \mathrm{Nd} /{ }^{144} \mathrm{Nd} d_{(130}$ Ma) results, ranging from 0.512334 to 0.512375 , with $\varepsilon N d$ values between -2.67 and -1.87 . TDM model ages vary from 1.01 to $1.07 \mathrm{Ga}$. On the other hand, ${ }^{87} \mathrm{Sr} /{ }^{86} \mathrm{Sr}(130 \mathrm{Ma})$ initial isotopic compositions showed a broader scatter, varying from 0.70321 to 0.70717 . The 
two low initial Sr values (Table 4 and Fig.11) are cautiously considered, as they do not follow the initial isotopic Nd pattern of the high-Ti group.

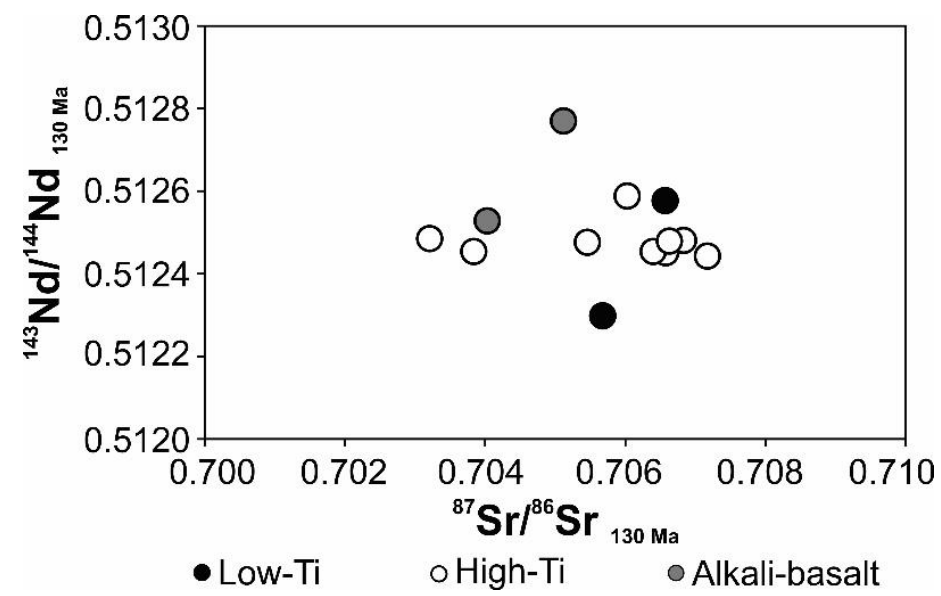

Figure 11 - Sardinha Formation initial ${ }^{87} \mathrm{Sr} /{ }^{86} \mathrm{Sr}-{ }^{143} \mathrm{Nd} /{ }^{144} \mathrm{Nd}$ isotopic ratios diagram.

The three Alkali-basalt samples produced different results when compared to the bulk Sardinha Formation data. Initial ${ }^{143} \mathrm{Nd} /{ }^{144} \mathrm{Nd}(130 \mathrm{Ma})$ values vary from 0.512344 to 0.512671 with $\varepsilon$ Nd ranging from -2.47 to +3.90 (Table 4). TDM model ages of two samples are similar to those of the Sardinha Formation rocks (ca. 0.91-0.97 Ga); however, the most primitive $\mathrm{Nd}$ isotopic data (DCO-52 sample with $\varepsilon_{\mathrm{Nd}}$ of +3.90 ) have a TDM model age of $0.45 \mathrm{Ga}$. The ${ }^{87} \mathrm{Sr} /{ }^{86} \mathrm{Sr}_{(130 \mathrm{Ma})}$ isotopic composition yielded two different results, one of 0.70512 (concordant with the overall expected results for the Sardinha Formation rocks) and one indicating a lower ratio (similar to the two unusual samples of the high-Ti group) at 0.70403 (Fig.11).

\subsection{Discussion}

\subsubsection{Comparison between the Mosquito and Sardinha formations}

The nature of the basaltic magmatism in the Parnaíba Basin is still not very well constrained. The distinction between the magmatic formations was believed to be possible only via age differences. Distinction from the type of outcrops, color and macrotextures were roughly made by Góes and Feijó (1994) and further acknowledged 
by other workers (da Silva et al., 2003; Vaz et al., 2007). However, no clear petrological and geochemical differences between the two formations were reported until now.

As previously described, the differences in petrographic features of these two groups of rocks may be recognized (Figs. 3 and 8 and topic 4 of this paper). When we evaluate groups described as high-Ti and low-Ti, in the Mosquito and Sardinha formations, they present differences in crystal size, mineralogical composition and texture. As shown in Fig.3c and Fig.3d the Mosquito low-Ti basalt samples are composed of glass, clinopyroxene, plagioclase and amygdules filled with calcite, in a typical intersertal texture characteristic of extrusive rocks (Fig.3b). In contrast low-Ti group of the Sardinha Formation (Figs. 8d and 8f), show differences relative to the Mosquito Formation, such as zoned clinopyroxene; a low-Ti Sardinha Formation basalt has a clinopyroxene crystal displaying an augite core and pigeonite rim (Fig. 8d) or olivine (Fig.8f shows a low-Ti Sardinha Formation olivine-basalt). The differences in crystal size (Sardinha Formation minerals are larger) and the lack of amygdules or vesicles are probably due to intrusive or subvolcanic emplacement of Sardinha Formation tholeiites. Such differences make the emplacement, crustal path and mantle source unlikely to be the same for both formations.

High-Ti rocks in both formations also present notable differences, as the Mosquito Formation basalts have large phenocrysts, unlike the Sardinha Formation high-Ti rocks. The phenocrysts have poikilitic or ophitic textures (Fig.3e, f) and are mostly unaltered. The groundmass is composed of clinopyroxene and plagioclase crystals forming an intersertal texture with devitrified glass. In contrast, high-Ti Sardinha rocks have mineral zonation, slightly altered mineral phases and late stage crystallization (Fig.8c, e). Sardinha Formation rocks have smaller crystal sizes. Differences in texture and mineralogy also account for different mantle sources and emplacement paths for the Mosquito and Sardinha high-Ti basalts.

The Alkali-basalt group is only present in the Sardinha Formation, which represents a major difference in relation to the Mosquito Formation. Alkali-basalts comprise mainly olivine-bearing gabbro/diabase (Fig.8g) or olivine basalt (Fig.8h). They have typically zoned diopside crystals with olivine and plagioclase inclusions. On Fig.8h euhedral diopside immersed in glassy matrix attests to an extrusive, more primitive 
component of the alkaline magmatism. Although these rocks are currently characterized as part of the Sardinha Formation magmatism, it is important to note that they seem to have been generated from a particular mantle source different from the Sardinha Formation tholeiites.

Similar to what was proposed by Peate et al. $(1990,1992)$ for the Paraná basalts, the Ti/Y and Ti/Zr ratios divide the Parnaíba Basin magmatic rocks into groups (Fig.12a). Considering these ratios, the Mosquito Formation basalts comprise two groups. The highTi group with high values of both ratios and the low-Ti rocks that have intermediate ratios (Ti/Y $\sim 300$ and Ti/Zr $\sim 70$ ). It is interesting to note that this does not apply to the Sardinha Formation. The high-Ti DCO-46 Sardinha Formation rock presents the lowest ratio (even lower than the Mosquito low-Ti basalts) whereas the rest of the high-Ti rocks of the Sardinha Formation have low values of $\mathrm{Ti} / \mathrm{Zr}$ but high $\mathrm{Ti} / \mathrm{Y}$ ratios (Fig.12a). The low- $\mathrm{Ti}$ quartz/hypersthene-normative Sardinha basalts have low values of those ratios, which are similar to the Mosquito low-Ti rocks, while low-Ti olivine/hypersthene-normative samples have higher values than any of the investigated samples (Fig.12a). The Sardinha Formation alkali-basalts presented similar results when compared with the high-Ti Sardinha Formation group with only slightly higher values of the Ti/Y ratio (Fig.12a).

The Mosquito Formation samples (both groups) have lower $\mathrm{Nb}$ and $\mathrm{Pb}$ contents, ranging in a narrow range of values (5 to 8 and 0.2 to $2.0 \mathrm{ppm}$, respectively) when compared to the Sardinha Formation rocks (Fig.12b). In contrast, the Sardinha Formation data vary within a wider range, depending on the group. Sardinha Formation low- $\mathrm{Ti}$ basalts have low $\mathrm{Nb}$ (6.7 to $17.8 \mathrm{ppm}$ ) and intermediate $\mathrm{Pb}$ (2 to $9 \mathrm{ppm}$ ) contents; the high-Ti group rocks have intermediate $\mathrm{Nb}$ (21.8 to $32.4 \mathrm{ppm}$ ) with a wide range of values for $\mathrm{Pb}$ (6 to $14 \mathrm{ppm}$ ); the alkali-basalts have high $\mathrm{Nb}$ (43 to $65.9 \mathrm{ppm}$ ) and intermediate $\mathrm{Pb}$ (2 to $6 \mathrm{ppm}$ ) contents (Fig.12b).

Mosquito Formation rocks have lower LREE/HREE ratios ( $\mathrm{La} / \mathrm{Yb}=2.49$ to 5.89 ). Although some low-Ti Sardinha Formation data overlap the low-Ti Mosquito trend, most of Sardinha Formation samples have much higher values $(\mathrm{La} / \mathrm{Yb}=4.74$ to 33.77; Fig.12c). The same occurs for Ni and Ta contents. Sardinha Formation rocks have higher Ta values and a wider variation in Ni contents (Fig.12d). 

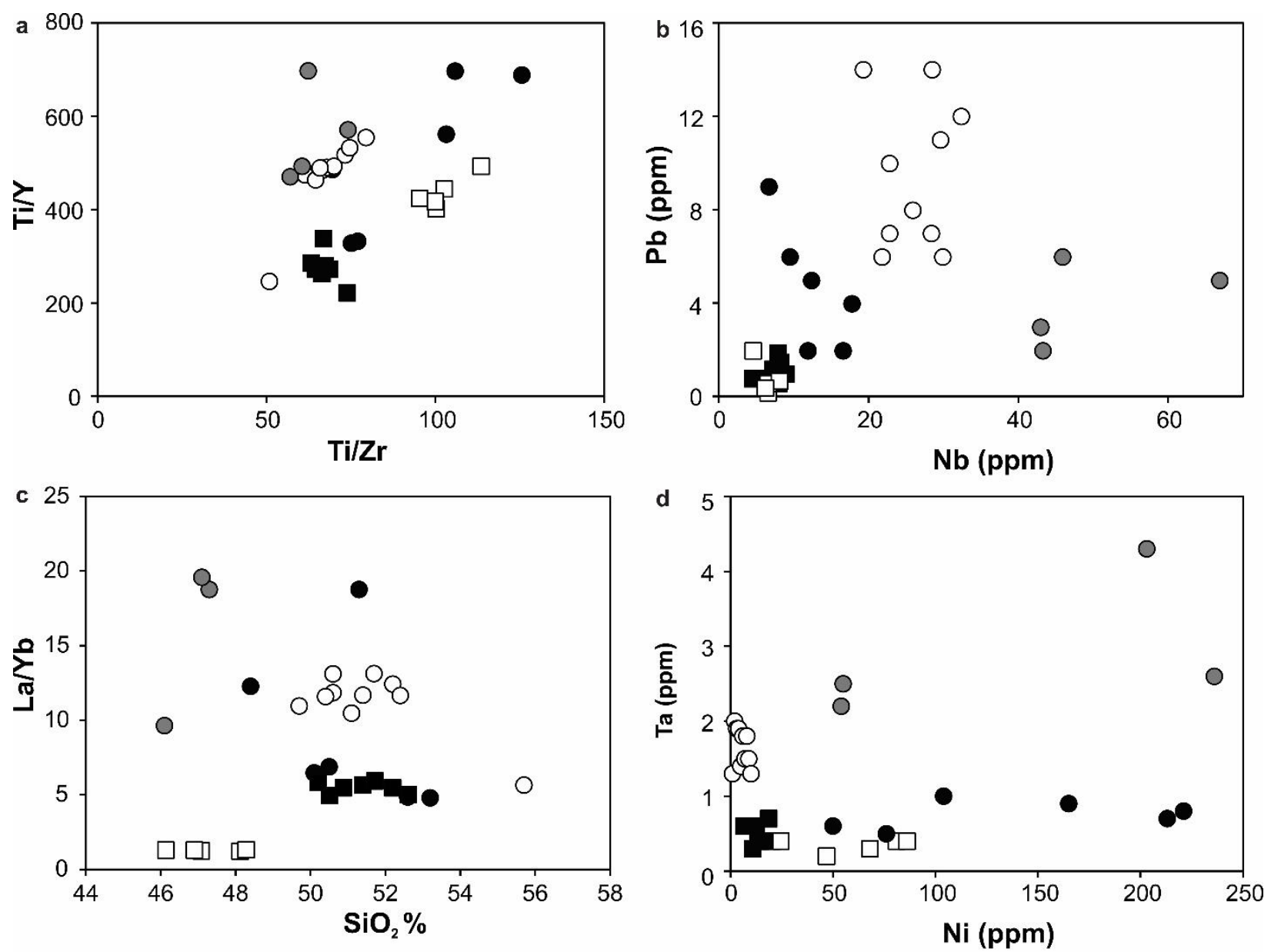

- MF Low-Ti $\square$ MF High-Ti • SF Low-Ti OSF High-Ti OSF Alkali-basalt

Figure 12 - Comparison plots between the Mosquito and Sardinha Formations, see text for detailed discussion.

In summary, the two basaltic formations of the Parnaíba Basin are distinguishable by their petrographic characteristics and major/trace element contents. The plots of the distinct groups regarding a variety of trace element data sets (e.g., Fig.12) reveal differences that can be observed by comparing the geochemical data of both formations. Sills and dykes that do not follow the overall geographical trend mentioned above may be characterized using some of these parameters. Therefore, age difference is not the only individual characteristic that can distinguish the two formations. The $\mathrm{Nb} v \mathrm{sb}$ diagram (Fig.12b), in particular, seems reliable for this purpose because the Mosquito Formation basalts have a negative $\mathrm{Nb}$ anomaly with variable (for low- $\mathrm{Ti}$ ) or negative (for high- $\mathrm{Ti}$ ) $\mathrm{Pb}$ anomaly (Fig.6) while Sardinha Formation rocks show slight or no $\mathrm{Nb}$ anomaly with positive $\mathrm{Pb}$ anomaly (Fig.10). Most CAMP samples from previous works range between 0 to 10 ppm of $\mathrm{Nb}$ and 0.5 to 6 ppm of Pb (Callegaro et al., 2013, 2014; Cirrincione et al., 
2014; Deckart et al., 2005; Marzoli et al., 2011; Merle et al., 2011) while PEMP data vary from 4.6 to 40 ppm of $\mathrm{Nb}$ and 3.8 to 16 ppm of Pb (Hartmann et al., 2012; Janasi et al., 2007; Lustrino et al., 2005; Mantovani and Hawkesworth, 1988; Marques et al., 1999; Peate and Hawkesworth, 1996; Peate et al., 1988, 1999; Santos Barreto et al., 2014; Schenato et al., 2003; Simon et al., 1999a, 1999b).

2.5.2. Mosquito and Sardinha basalts and their correlation with CAMP, PEMP and EQA events

The Mosquito and Sardinha geochemical and isotopic characteristics are related to basaltic events of continental proportions such as the CAMP, PEMP and EQA events (Baksi and Archibald, 1997; Fodor et al., 1990; Góes and Feijó, 1994; Marzoli et al., 1999; da Silva et al., 2003; Vaz et al., 2007; Merle et al., 2011). Additional to the age similarities (not discussed in this paper, see Baksi and Archibald, 1997 and Mizusaki et al., 2002 for references), the major and trace element geochemical properties also indicate similarities between magma types that comprise the other CFB provinces.

The CAMP is an extensive CFB that covers large areas in Europe, Africa, North America and South America (Marzoli et al., 1999). It has been the object of geochemical and isotopic studies for many years. The Mosquito Formation data are comparable to those of the published CAMP data and most geochemical and isotopic signatures plot accordingly to the CAMP range of compositions (Fig.13). The high-Ti Mosquito Formation rocks are compositionally very similar to the high-Ti CAMP samples, having $\mathrm{TIO}_{2} \%$ higher than $1.5 \%$ wt.\% and Mg\# between 15 and 50 (Fig.13a, b). The similarity is also valid for trace element contents (Fig.13c) and for their high initial Sr isotopic signatures (Fig.13d). The low-Ti Mosquito basalts are also similar in terms of their major and trace elements (Fig.13a, b and c). The initial isotopic signature of the low-Ti Mosquito Formation rocks do not follow exactly the overall pattern of the low-Ti CAMP and the data have slightly more radiogenic $\mathrm{Sr}$ signature with $\varepsilon N d$ negative values closer to some low-Ti CAMP values (Fig.13d). Together with age similarities and in agreement with earlier workers, the data presented here characterize the Mosquito Formation as a CAMP-related basaltic province. 

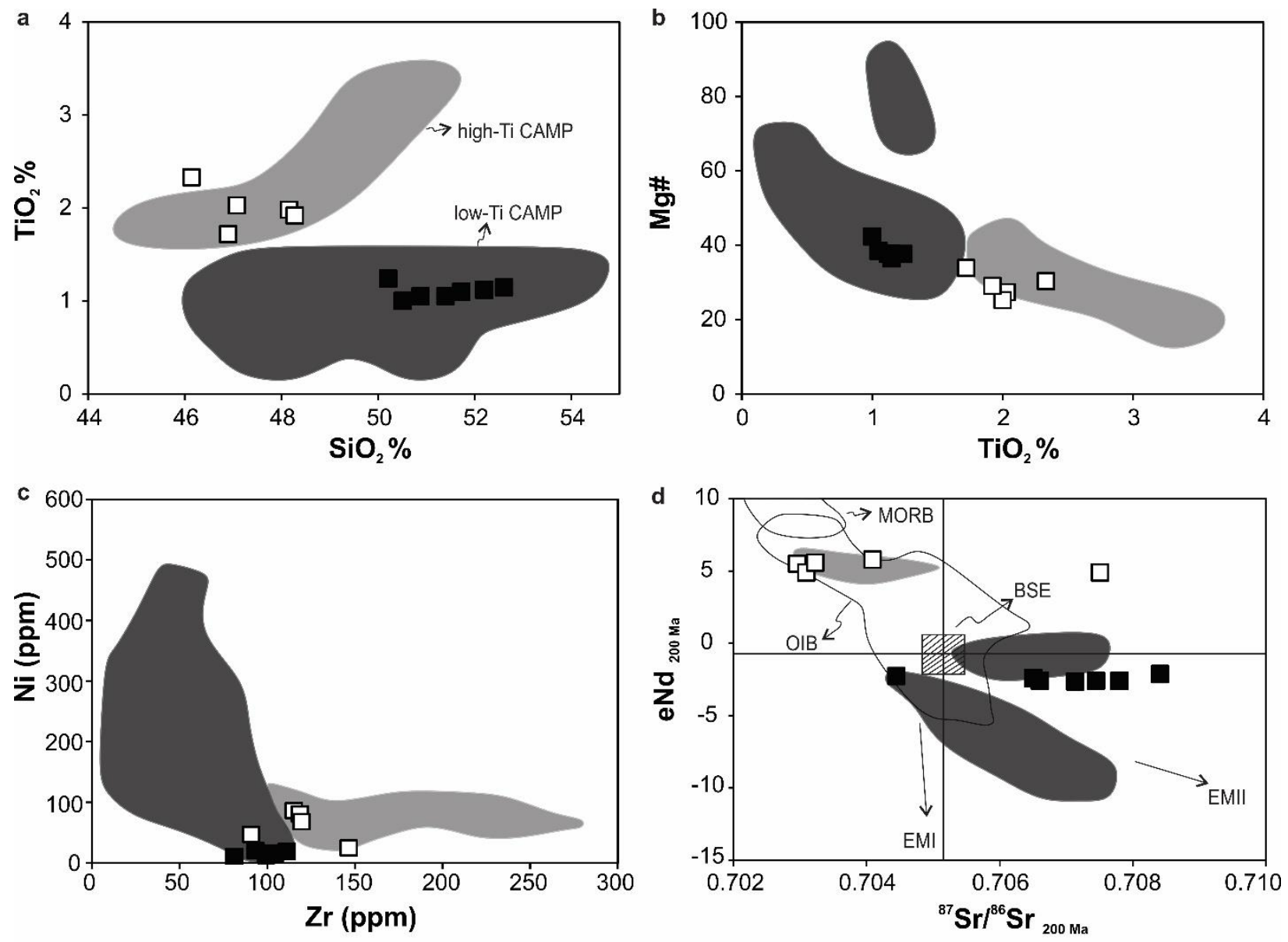

- Low-Ti Mosquito $\square$ High-Ti Mosquito

Figure 13 - Mosquito Formation and CAMP analyzes for major and trace elements and initial Nd-Sr isotope data. The high- and low-Ti compositions are similar to those of the African (Bensalah et al., 2011; Bertrand et al., 1982; Chabou et al., 2010), European (Callegaro et al., 2013, 2014; Cebriá et al., 2003; Cirrincione et al., 2014; Martins et al., 2008), North (Marzoli et al., 2011) and South American (Deckart et al., 2005; Merle et al., 2011) CAMP event. MORB, OIB, BSE, EMI and EMII isotopic compositions are those suggested by Zindler and Hart (1986).

On the other hand, the comparison between the Sardinha Formation is not so straightforward. Age similarities with the PEMP (Renne et al., 1992, 1996a, 1996b) and EQA events (Hollanda et al., 2006 and references therein), demonstrate that these magmatic events are associated with the opening of the Southern or Equatorial Atlantic Ocean. Still, the geographical location related to the PEMP and the lack of data for the EQA hinders the characterization of its genesis. The general compositional variation that characterizes the Sardinha Formation increases the difficulty in identifying a pattern to investigate its petrogenesis. Yet, the broad compositional variation is also a characteristic of the PEMP basalts. Peate et al (1992) recognized six different magma types regarding their geochemical compositions and stratigraphy in the Paraná Basin. Similarly, if we 
consider sub-categories in the Sardinha Formation where diverse major and trace element compositions in the high- and low-Ti groups may comprise different magma types, the Sardinha Formation would prove to be similar to the PEMP basalts in some of the geochemical features (Fig.14a, b). For example, sample DCO-46 might represent a magma type similar to the Gramado-type and the remaining high-Ti samples may be compared to the Urubici-type basalts of the PEMP (Fig.14a, b). The same is observed if we separate the quartz/hypersthene-normative rocks from the olivine/hypersthenenormative low-Ti Sardinha basalts. One may be compared to the Esmeralda-type magma while the other is equivalent to the Pitanga-type (Fig.14a, b). However, using $\mathrm{TiO}_{2}$ contents, the correlation between Sardinha and PEMP magmatism is not corroborated. Only the bulk high-Ti Sardinha Formation continues to be related to the Urubici-type magma while all other samples vary differently from the observed on the Fig.14a and $b$ (Fig.14c). Noteworthy, the EQA province is geographically close to the exposures of the Sardinha Formation. Hence, it might represent the most similar magmatic event, not only in terms of location but also in genesis. However, the overall values for trace element contents correlate only with the high-Ti of the Sardinha Formation and is not comparable to the other Sardinha rocks. This means either that the Sardinha Formation is not comparable to the EQA province or that the EQA rocks have more diverse composition in the Parnaíba Basin than what is observed in the Borborema Province, where it was first described.

The EQA and PEMP Sr-Nd isotopic signatures overlap, in addition to most of the Sardinha Formation rocks. Most of the high and low-Ti Sardinha Formation data range close to the PEMP and EQA ratios and may represent small variations of those (Fig.14d). However, since most data overlap each other, it is not a great parameter of comparison.

Analyzing diagrams of Fig.14 for the alkali-basalts, it is apparent that they are to some extent similar to the Ponta Grossa dykes of the Paraná Basin. The Ponta Grossa Suite is considered the feeding system for the high-Ti magmatism of the northern PEMP occurrences in the Paraná Basin (Piccirillo et al., 1990; Renne et al., 1996a). The dykes used by the authors mentioned are mainly tholeiitic rocks, varying from basalts to andesitic basalts, very different from the alkaline nature of the alkali-basalts of the Sardinha group. However, the Ponta Grossa Suite have also an alkaline component that 
is commonly related to mantle plume heads, similar to other alkaline igneous intrusions around the Paraná Basin, such as the Serra do Mar Alkaline Province and Alto Paranaíba Igneous Province (Gibson et al., 1995a, 1995b; Gomes et al., 2011; Thompson et al., 1998). Those alkaline rocks are generally younger (c.a. 80Ma) than the overall PEMP magmatism (ca. $130 \mathrm{Ma}$ ) and are related to the Tristan da Cunha or Trindade mantle plumes, differently from the SCLM source of the PEMP rocks (Gibson et al., 1995b). The association between the alkali-basalt group and tholeiites of the Sardinha Formation is poorly constrained. Although there are similarities between the basalts, the alkaline rocks of the Sardinha Formation may have originated from a different source of that of the Sardinha Formation high- and low-Ti basalts, thus originating from a mantle plume similarly to the alkaline magmatism of the Paraná Basin. The isotopic data are also variable and scarce to support any of these assumptions. Nonetheless, the alkali-basalt group of the Sardinha Formation do not follow the overall pattern of the PEMP or of the EQA (Fig.14d). In addition, the Fernando de Noronha (FN) alkaline basalts are also referenced with similar ratios to the alkali-basalt group, although results of the Sardinha Formation and the FN do not overlap each other.

In conclusion, the Mosquito Formation is well defined as part of the CAMP magmatism. However, the Sardinha Formation still requires further investigation to evaluate whether or not it can be related to the PEMP or EQA magmatism and to better constrain the alkali-basalt group relations to the other Sardinha Formation rocks and nearby alkaline magmatism.

\subsubsection{Geochemical modelling}

Differences in geochemical characteristics of the two basaltic formations may be used to infer that multiple mantle sources were responsible for the various magma types recognized in the Parnaíba Basin. Taking into account different degrees of interaction between the mantle-generated liquids and ascent through shallower mantle or continental crust, these magma types could result from contamination with other mantle end members and/or Archean/Proterozoic terranes that comprise the basement of the basin. 

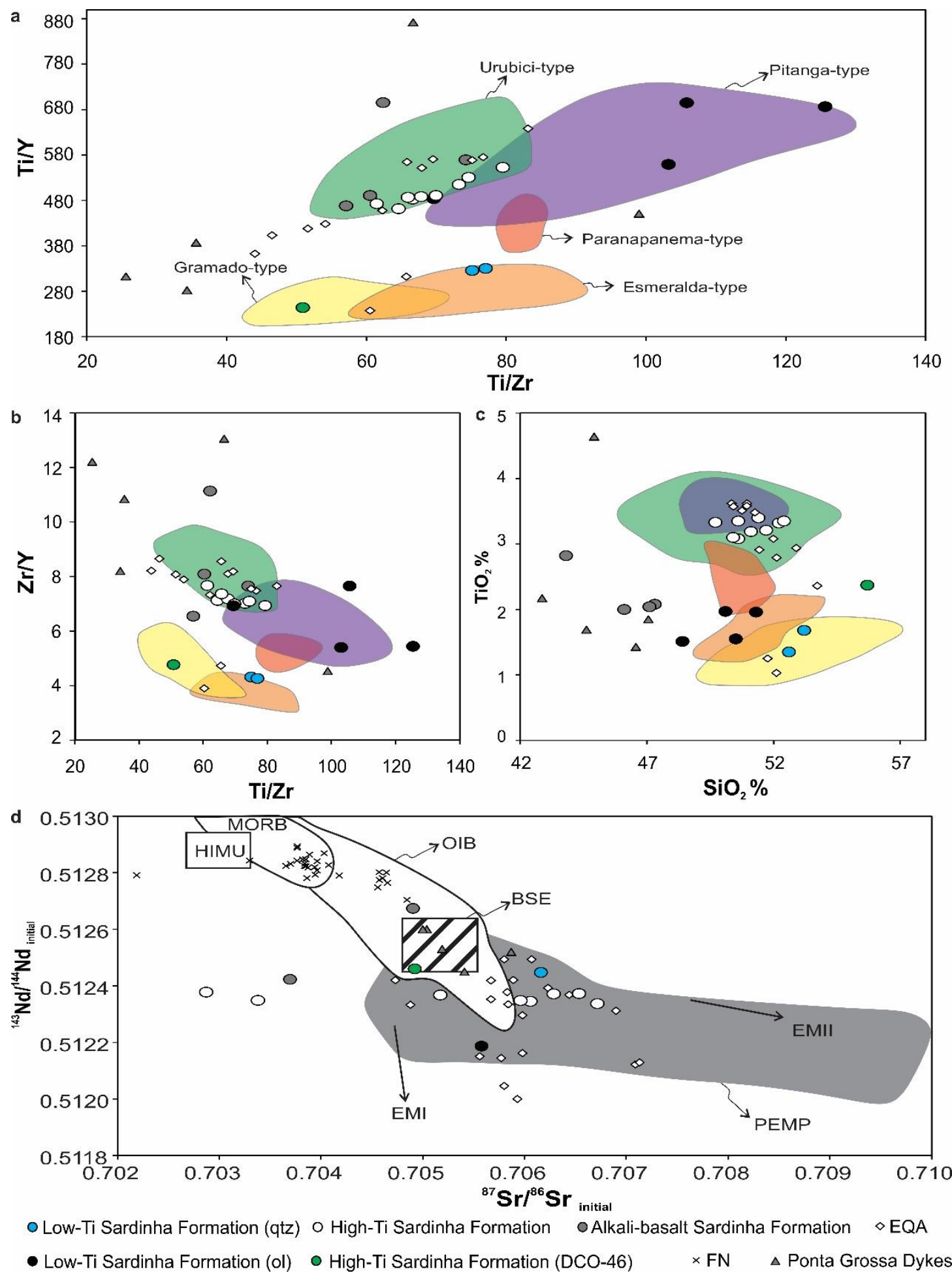

Figure 14 - Comparison between the Sardinha Formation, Fernando de Noronha (FN) basalts, PEMP and EQA magmatic events. Color designated fields represent PEMP-basalt types of the Paraná Basin. FN compositions from Gerlach et al (1987). PEMP compositions from Cordani et al (1988), Ewart et al (2004), Garland et al. (1995, 1996), Gibson et al (1999), Hawkesworth et al. (1992), lacumin et al (1991), Kirstein et al (2000), Mantovani and Hawkesworth (1988), Marques et al (1989, 1999), Peate and Hawkesworth (1996), Peate et al (1990, 1992, 1996, 1999), Petrini et al (1987), Rämö et al (2016), Rocha-Junior et al (2012, 2013), Simon et al (1999a, 1999b). EQA composition from Hollanda et al (2006). Ponta Grossa (PG) dykes from Piccirillo et al (1990). HIMU, MORB, OIB, BSE, EMI and EMII isotopic compositions from Zindler and Hart (1986). 
The main feature investigated was whether the magmas represent a mixture of different mantle end-members that took place before the ascent to the magma chamber or if magma was later contaminated by continental crust. For this purpose, the AFC equations of DePaolo (1981) were used to generate mixing lines between mantle endmembers (e.g., DMM, HIMU and OIB) and other mantle sources (e.g., EMI, EMII and SCLM) or crustal material (i.e., Seridó Domain of the Borborema Province referred as SJS and SJE from Hollanda et al., 2003). The compositional gaps between high and lowTi basalts in both the Mosquito and Sardinha Formations suggest at least two distinct sources for each formation, as Merle et al (2011) suggested for the Mosquito Formation and Deckart et al (2005) argued for the intrusive rocks of the CAMP in Guyana and Guinea.

Modelling the possible mantle end-members and crustal components responsible for the contamination of magmas in the Parnaíba Basin is difficult at this point due to the lack of mantle xenoliths and knowledge about the basement composition directly underneath the basin. It is mostly accepted by geophysical data that Archean and Neoproterozoic terranes (Daly et al., 2014) are the main basement rocks that underlie the Parnaíba Basin, but geochemical and isotopic analyses are not available. Hollanda et al (2003) published isotopic compositions of the Seridó domain (northeast of the Parnaíba Basin) and although it does not necessarily reflect a possible continental crust contamination rock of the Mosquito and Sardinha basalts, the different Precambrian rock types (i.e., tonalites, gneisses, and metasedimentary rocks) were used to constrain possible crustal contaminants. Considering the $\mathrm{Mg \#}$ and compatible element composition, there are no data that can be considered as representative of the primitive magma in the studied samples. Isotopic characteristics of the Mosquito and Sardinha basalts are close to CHUR ${ }^{143} \mathrm{Nd} /{ }^{144} \mathrm{Nd}$ composition with more radiogenic crustal-like ${ }^{87} \mathrm{Sr} /{ }^{86} \mathrm{Sr}$ ratios. The exceptions are the high-Ti Mosquito samples, the alkali-basalts and few high-Ti Sardinha samples (higher ${ }^{143} \mathrm{Nd} /{ }^{144} \mathrm{Nd}$ or lower ${ }^{87} \mathrm{Sr} /{ }^{86} \mathrm{Sr}$ ratios compared to the BSE) that indicate a more primitive mantle source. Because there are no primitive magma samples, we chose to model using average compositions of mantle end-members such as DMM, OIB, MORB and HIMU. OIB and MORB compositions yielded tie lines 
similar to the DMM; as a result, MORB and OIB sources were not included in the model but may be inferred to produce similar results to the DMM mantle source (Figure 15).

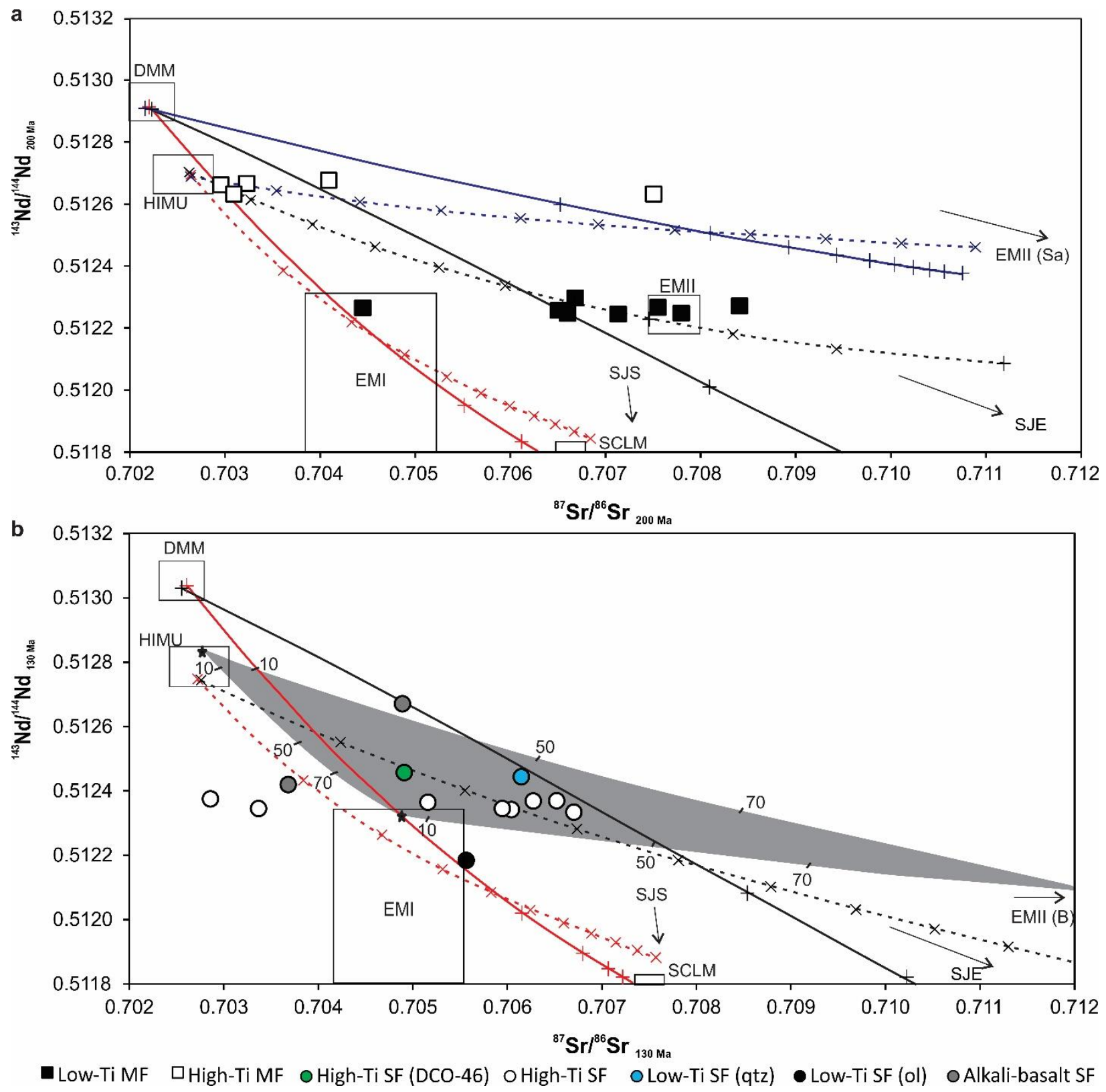

Figure 15 - Assimilation and Fractional Crystallization model for initial isotopic ${ }^{87} \mathrm{Sr} /{ }^{66} \mathrm{Sr}$ vs ${ }^{143} \mathrm{Nd} /{ }^{144} \mathrm{Nd}$ compositions of the Mosquito (a) and Sardinha (b) Formations using DMM and HIMU mantle end-members as primary sources for the basalts. Solid and dashed lines mark DMM (Workman and Hart, 2005) and HIMU (Hanyu et al., 2011) end-members as primary sources, respectively. Colors indicate contaminants or assimilants; blue for EMII(Sa) (Samoa Islands; Jackson et al., 2007), black for SJE (K-diorites and granites of the Seridó Domain; Hollanda et al., 2003), red for SCLM (average lamproite composition; Rock, 1991). Cross and X marks indicate Fractional Crystallization percentage from the source to assimilants by additional $10 \%$ for each marker from DMM and HIMU, respectively. The gray field indicates a ternary plot with HIMU, EMI (Zindler and Hart, 1986) and EMII(B) (Ben Othman et al., 1989) as mantle end-members, tick marks with numbers indicate the mixing proportions between the isotopic compositions for each end-member (black star). EMII composition from Zindler and Hart (1986). SJS (tonalities of the Seridó Domain) isotopic composition from Hollanda et al (2003). Fields assigned by arrows plot outside the graph isotopic values. 
High-Ti Mosquito Formation basalts yielded isotopic compositions similar to those of the average HIMU-type mantle end-member and represent mostly uncontaminated rocks. Two high-Ti Mosquito samples that are different from the bulk composition of this magma type might be the product of contamination with a more radiogenic-Sr source such as the EMII (considered as the Samoa Islands isotopic composition) or with continental crust not used in the AFC model (Figure 15). The bulk high-Ti basalts of the Sardinha Formation present two isotopic compositional clusters: one poorly constrained as HIMU-type magmas with $10 \%$ of fractional crystallization (FC), considering olivine, plagioclase and clinopyroxene as fractionated minerals, and the assimilation of a SCLM component. Along with another set of high-Ti Sardinha basalts, that comprises approximately $30 \%$ of FC with contamination with a SJE (i.e., K-diorites and granites) crustal component (Figure 15). This suggests that high-Ti Sardinha basalts may have had a mantle source similar to their Mosquito Formation high-Ti counterparts (HIMU end member), but with different emplacement paths and larger interaction with other mantle end-members or crustal rocks.

Considering the fractionation mineral assemblage including olivine, plagioclase and clinopyroxene, the low-Ti basalts of the Mosquito Formation follow a model suggesting origin in a DMM-like source followed by contamination with the SCLM or with crustal component such as the SJE including $35-40 \%$ of FC (Fig.15). Additionally, most low-Ti Mosquito Formation samples plot near or within the EMII field of Zindler and Hart (1986). These samples may also be interpreted as generated directly from the metasomatised subcontinental continental lithospheric mantle (Merle et al., 2011). LowTi Sardinha basalts did not yield reliable isotopic results and only two samples were used in the AFC model. The data is not very well constrained regarding mantle sources and assimilation materials. However, the quartz-hypersthene normative sample plots just below the DMM-SJE tie line at approximately $25 \%$ of $F C$, suggesting an origin similar to the low-Ti Mosquito Formation basalts. The olivine-hypersthene normative rock composition indicate a HIMU-type mantle source with $30 \%$ FC and may represent a more evolved term of the low-Ti Sardinha basalts. Another possible origin for this group is a DMM source, followed by assimilation of SCLM material. This model is acceptable 
because the composition of the sample plots very close to that tie line. However, to constrain the origin of the low-Ti Sardinha basalts additional data are required.

The two alkali-basalt samples of the Sardinha Formation modelled using their isotopic ratios also fits the AFC model with $10 \%$ FC of a HIMU-type source mixed with a SCLM or EMII (Samoa Islands) component (Figure 15). Because there are only two samples of the alkali-basalt group and they plot on very different portions of the graph the AFC model for such samples require more data to be better established.

Additionally, mixing tie-lines between the HIMU, EMI and EMII composition of Ben Othman et al (1989) comprises most of the Sardinha Formation basalts (gray field in Fig. 15). This is similar to what is observed for the EQA basalts (Hollanda et al., 2006). Hollanda et al (2006) proposed that heat transfer from a plume must have been responsible for the melting of an enriched sub-continental lithospheric mantle from which those tholeiites were derived. This may be extrapolated that to the genesis of the Sardinha basalts.

Although the AFC paths of the Mosquito and Sardinha basalt groups still need to be better understood, these simple AFC models show general features that can be used to roughly identify the source materials and crustal components responsible for the formation of both Mosquito and Sardinha igneous rocks. Furthermore, they underline the obvious inference that high- and low-Ti rocks, as well as the alkali-basalts, have distinct mantle sources and emplacement paths through the continental crust.

\subsection{Conclusion}

Magmatic rocks are exposed in large areas of the central and NE parts of the Parnaíba Basin, being responsible for an important part of the subsidence and thermal development of the basin. As pointed out by Thomaz Filho et al. (2008) the magmatic events are intimately related to the generation, migration and accumulation of oil and gas in most Brazilian Paleozoic Basins, including the Parnaíba Basin. A number of geophysical studies financed by oil companies are in progress, in order to investigate the relative roles and extent of the Mosquito and Sardinha magmatic events in the oil and gas generation and migration in the Parnaíba Basin. For this purpose, the geochemical 
characterization of each event is an important tool to understand the origin of the mafic sills that intrude the inner portion of the basin and possibly helped to generate most of the hydrocarbon found. The age differences were believed to be the only reliable source of information regarding the differentiation between the two events, but geochemical evidence is also helpful to understand and characterize dykes, sills and basalt flows. The trace elements (e.g., Fig.12) can be also a reliable indicator for each particular magmatic event.

Aside from the differentiation between the two magmatic formations, the Mosquito Formation is undeniably related to the CAMP. The Sardinha Formation basalts, on the other hand, still requires further investigation to determine their compositional variation and correlation with other CFB in the South American platform. Its relation to the PEMP and EQA events is possible but not straightforward, requiring additional studies. Even more controversial is the alkali-basalt component of the Sardinha Formation that may be an entirely different magmatic event in composition, age or genesis. It may also represent an alkaline component of the Sardinha magmatism originated by a mantle plume source or lower degrees of mantle melting. Detailed dating of the Sardinha Formation is essential in future studies.

The mantle sources of the basaltic magmatism in the basin are in close relation to enriched mantle end-members beneath the basin. The Mosquito Formation is believed to be originated from the SCLM (Merle et al., 2011) or from EMI or EMII mantle components. The HIMU composition of the mantle could also be a contributor to the genesis of the high-Ti compositions. The origin of the Sardinha magmas origin is somewhat more controversial. Multiple geochemical and isotopic magma-types require a more complex genesis (such as the PEMP magmatism in central and southern Brazil). It is evident that for its formation, a multifaceted mantle source is essential and the crustal evolution through the continental crust could account for assimilation of continental material. The most probable origin is related with HIMU, EMI and EMII components (as shown in Fig.15). However, the data are still insufficient for a reliable characterization of mantle sources for the Sardinha Formation basalts. Additionally, plume-derived melts could account for some magma types such as the alkali-basalts, similar to the nearby Fernando de Noronha archipelago, and may be, to some extent, part of the origin of this magmatism. 
The Parnaíba Basin represents an important area for tectonic, geophysical, petrological and sedimentological studies. Additional knowledge resulting from further studies will be instrumental to characterize not only the magmatism but also its relationship with the mechanisms of basin formation and evolution as well as hydrocarbon origin associated with magmatic thermal events.

\subsection{References}

Almeida, F.F.M., 1986. Distribuição regional e relações tectônicas do magmatismo pósPaleozóico no Brasil. Revista Brasileira de Geociências 16, 325-349.

Andersen, D.J., Lindsley, D.H., Davidson, P.M., 1993. QUILF: a Pascal program to assess equilibria among $\mathrm{Fe}-\mathrm{Mg}-\mathrm{Mn}-\mathrm{Ti}$ oxides, pyroxenes, olivine, and quartz. Computers \& Geosciences Vol. 19, No. 9, pp. 1333-1350.

Angelim, L.A.A., Vasconcelos, A.M., Gomes, J.R..C., Wanderley, A.A., Forgiarini, L.L., Medeiros, M. de F., 2004. Folha SB.24-Jaguaribe, in: Schobbenhaus, C., Gonçalves, J.H., Santos, J.O.S., Abram, M.B., Leão Neto, R., Matos, G.M.M., Vidotti, R.M., Ramos, M.A.B., Jesus, J.D.A. de. (Eds.), Carta Geológica do Brasil ao Milionésimo, Sistemas de Informações Geográficas. Programa Geologia do Brasil. CPRM, Brasília.

Bahia, R.B.C., Faraco, M.T.L., Monteiro, M.A.S., Oliveira, M.A.O., 2004. Folha SA.22Belém, in: Schobbenhaus, C., Gonçalves, J.H., Santos, J.O.S., Abram, M.B., Leão Neto, R., Matos, G.M.M., Vidotti, R.M., Ramos, M.A.B., Jesus, J.D.A. de. (Eds.), Carta Geológica do Brasil ao Milionésimo, Sistemas de Informações Geográficas. Programa Geologia do Brasil. CPRM, Brasília.

Baksi, K.A. e Archibald, D.A., 1997. Mesozoic igneous activity in the Maranhão province, northern Brazil: 40Ar/ 39Ar evidence for separate episodes of basaltic magmatism. Earth and Planetary Science Letters 151, 139- 153.

Bellieni, G., Comin-Chiaramonti, P., Marques, L.S., Melfi, A.J., Piccirillo, E.M., Stolfa, D., 1984. Low-Pressure Evolution of Basalt Sills from Bore-Holes in the Paraná Basin, Brazil. Tschermaks Mineralogische und Petrographische Mitteilungen 33, 25-47.

Bellieni, G., Piccirillo, E.M., Cavazzini, G., Petrini, R., Comin-Chiaramonti, P., Nardy, A.J.R., Civetta, L., Melfi, A.J., Zantedeschi, P., 1990. Low- and high TiO2, Mesozoic tholeiitic magmatism of the Maranhão basin (NE-brazil): $\mathrm{K}-\mathrm{Ar}$ age, geochemistry, petrology, isotope characteristics and relationships with Mesozoic low- and high TiO2 flood basalts of the Paraná Basin (SE-Brazil). Neues Jahrbuch. Mineralogischer Abhandlungen 162, 1-33. 
Ben Othman, D., White, W.M., Patchett, J., 1989. The geochemistry of marine sediments, island arc magma genesis, and crust-mantle recycling. Earth and Planetary Science Letters $91,1-21$.

Bensalah, M.K., Youbi, N., Mahmoudi, A., Bertrand, H., Mata, J., El Hachimi, H., Madeira, J., Martins, L., Marzoli, A., Bellon, H., Medina, F., Karroum, M., Karroum, L.A., Ben Abbou, M., 2011. The Central Atlantic Magmatic Province (CAMP) volcanic sequences of Berrechid and Doukkala basins (Western Meseta, Morocco): volcanology and geochemistry. Comunicações Geológicas 98, 15-27.

Bertrand, H., Dostal, J., Dupuy, C., 1982. Geochemistry of Early Mesozoic tholeiites from Morocco. Earth and Planetary Science Letters 58, 225-239.

Bertrand, H., Fornari, M., Marzoli, A., García-Duarte, R., Sempere, T., 2014. The Central Atlantic Magmatic Province extends into Bolivia. Lithos 188, 33-43.

Bleeker, W., Ernst, R., 2006. Short-lived mantle generated magmatic events and their dyke swarms: the key unlocking Earth's paleogeographic record back to $2.6 \mathrm{Ga}$, in: Hanski, E., Mertanen, S., Rämö, T., Vuollo, J. (Eds.), Dyke Swarms - Time Markers of Crustal Evolution. Taylor \& Francis/Balkema, The Netherlands, pp. 326.

Brito Neves, B.B., Fuck, R.A., Cordani, U.G., Thomaz Filho, A., 1984. Influence of basement structures on the evolution of the major sedimentary basins on Brazil: a case of tectonic heritage. Journal of Geodynamics 1, 495-510.

Brito Neves, B.B., Dos Santos, E.J., Van Schmus, W.R., 2000. Tectonic history of the Borborema Province, northeastern Brazil. In: Cordani U, Milani EJ, Thomaz Filho A, Campos DA (Eds.), Tectonic evolution of South America. 31st International Geological Congress, Rio de Janeiro, Brazil, pp 151-182.

Bryan, S.E., Ernst, R.E., 2008. Revised definition of Large Igneous Provinces (LIPs). Earth-Science Reviews 86, 175-202.

Callegaro, S., Marzoli, A., Bertrand, H., Chiaradia, M., Reisberg, L., Meyzen, C., Bellieni, G., Weems, R.E., Merle, R., 2013. Upper and lower crust recycling in the source of CAMP basaltic dykes from southeastern North America. Earth and Planetary Science Letters 376, 186-199.

Callegaro, S., Rapaille, C., Marzoli, A., Bertrand, H., Chiaradia, M., Reisberg, L., Bellieni, G., Martins, L., Madeira, J., Mata, J., Nasrrddine, Y., DeMin, A., Azevedo, M.R., Bensalah, M.K., 2014. Enriched mantle source for the Central Atlantic magmatic province: New supporting evidence from southwestern Europe. Lithos 188, 15-32.

de Castro, D.L., Fuck, R.A., Phillips, J.D., Vidotti, R.M., Bezerra, F.H.R., Dantas, E.L., 2014. Crustal structure beneath the Paleozoic Parnaíba Basin revealed by 
airborne gravity and magnetic data, Brazil, Tectonophysics, 614, 128-145, doi:10.1016/j.tecto.2013.12.009.

Cebriá, J.M., Lopez-Ruiz, J., Doblas, M., Martins, L.T., Munha, J., 2003. Geochemistry of the Early Jurassic Messejana-Plasencia dyke (Portugal-Spain); implications on the origin of the Central Atlantic Magmatic Province. Journal of Petrology 44, 547568.

Chabou, M.C., Bertrand, H., Sebaï, A., 2010. Geochemistry of the Central Atlantic Magmatic Province (CAMP) in south-western Algeria. Journal of African Earth Sciences 58, 211-219.

Cirrincione, R., Fiannaca, P., Lustrino, M., Romano, V., Tranchina, A., 2014. Late Triassic tholeiitic magmatism in Western Sicily: A possible extension of the Central Atlantic Magmatic Province (CAMP) in the Central Mediterranean area?. Lithos 188, 6071.

Coffin, M.F., Eldholm, O., 1991. Large Igneous Provinces: JOI/USSAC workshop report. The University of Texas at Austin Institute for Geophysics Technical Report, p. 114.

Coffin, M.F., Eldholm, O., 1992. Volcanism and continental break-up: a global compilation of large igneous provinces, in: Storey, B.C., Alabaster, T., Pankhurst, R.J. (Eds.), Magmatism and the Causes of Continental Break-up. Geological Society of London Special Publication, vol. 68, pp. 17-30.

Coffin, M.F., Eldholm, O., 1993a. Scratching the surface: estimating dimensions of large igneous provinces. Geology 21, 515-518.

Coffin, M.F., Eldholm, O., 1993b. Large igneous provinces. Scientific American 269, 4249.

Cordani, U.G., Civetta, L., Mantovani, M.S.M., Peirce, J.W., Kawashita, K., Hawkesworth, C.J., Taylor, P., Longinelli, G., Cavazzini, G., Piccirillo, E.M., 1988. Isotope geochemistry of flood volcanics from the Parana Basin (Brazil), in: Piccirillo, E.M., Melfi, A.J. (Eds.), The Mesozoic Flood Volcanism of the Paraná Basin. Universidade de São Pauto, Instituto Astronômico e Geofísico, 157-178.

Cordani, U.G., Teixeira, W., D'Agrella, M.S., Trindade, R.I., 2009. The position of the Amazonian Craton in supercontinents. Gondwana Research 15 (3-4), 396-407.

Costa, J., Vasconcellos, E.M.G., Barros, C.E.M., Cury, L.F., Juk, K.F.V. 2012. Petrologia e geoquímica da soleira de Medicilândia, diabásio Penatecaua, PA. Revista Brasileira de Geociências, volume 42(4): 754-771. 
Courtillot, V.E., Renne, P.R., 2003. On the ages of flood basalt events. Comptes Rendus Geoscience 335, 113-140.

Cunha, P.R.C., de Melo, J.H.G., da Silva, O.B. 2007. Bacia do Amazonas. Boletim de Geociências da Petrobrás, Rio de Janeiro, v. 15, n. 2, p. 227-251.

da Silva, A.J.P., Lopes, R.C.L., Vasconcelos, A.M., Bahia, R.B.C., 2003. Bacias Sedimentares Paleozóicas e Meso-Cenozóicas Interiores, in: Geologia, Tectônica e Recursos Minerais do Brasil. L. A. Bizzi, C. Schobbenhaus, R. M. Vidotti e J. H. Gonçalves (Eds.), CPRM, Brasília.

Daly, M.C., Andrade, V., Barousse, C.A., Costa, R., McDowell, K., Piggott, N. and Poole, A. J., 2014. Brasiliano crustal structure and the tectonic setting of the Parnaíba basin of NE Brazil: Results of a deep seismic reflection profile. Tectonics, 33, doi: 10.1002/2014TC003632.

DePaolo, D.J. 1981. Trace element and isotopic effects of combined wallrock assimilation and fractional crystallisation. Earth and Planetary Science Letters, 53, 189-202.

Deckart, K., Bertrand, H., Liégeois, J.P., 2005. Geochemistry and Sr, Nd, Pb isotopic composition of the Central Atlantic Magmatic Province (CAMP) in Guyana and Guinea. Lithos 82, 289- 314.

Deckart, K., Féraud, G., Bertrand, H. 1997. Age of Jurassic continental tholeiites of French Guyana, Surinam and Guinea: Implications for the initial opening of the Central Atlantic Ocean. Earth and Planetary Science Letters 150, 205-220.

Eiras, J.F., Becker, C.R., Souza, E.M., Gonzaga, F.G., da Silva, J.G.F., Daniel, L.M.F., Matsuda, N.S., Feijó, F.J. 1994. Bacia do Solimões. Boletim de Geociências. Petrobrás, Rio de Janeiro, 8(1): 17-45.

Ewart, A., Marsh, J.S., Milner, S.C., Duncan, A.R., Kamber, B.S., Armstrong, R.A., 2004. Petrology and geochemistry of Early Cretaceous bimodal continental flood volcanism of the NW Etendeka, Namibia. Part 1: introduction, mafic lavas and reevaluation of mantle source components. Journal of Petrology 45 (1), 59-105.

Faraco, M.T.L., Marinho, P.A.C., Vale, A.G., Costa, E.J.S., Maia, R.G.N., Ferreira, A.L., Valente, C.R., Lacerda Filho, J.V., Moreton, L.C., Camargo, M.A., Vasconcelos, A.M., Oliveira, M., Oliveira, I.W.B., Abreu Filho, W.A., Gomes, I.P., 2004a. Folha SB.22-Araguaia, in: Schobbenhaus, C., Gonçalves, J.H., Santos, J.O.S., Abram, M.B., Leão Neto, R., Matos, G.M.M., Vidotti, R.M., Ramos, M.A.B., Jesus, J.D.A.de. (Eds.), Carta Geológica do Brasil ao Milionésimo, Sistema de Informações Geográficas. Programa Geologia do Brasil. CPRM, Brasília.

Faraco, M.T.L., Marinho, P.A.C., Vale, A.G., Costa, J.S., Ferreira, A.L., Valente, C.R., Lacerda Filho, J.V., Moreton, L.C., Camargo, L.C., Camargo, M.A., Frasca, A.A., 
Ribeiro, P.S.E., Vasconcelos, A.M., Oliveira, M., Oliveira, I.W.B., Abreu Filho, W., Gomes, I.P. 2004b. Folha SC.22-Tocantins, in: Schobbenhaus, C., Gonçalves, J.H., Santos, J.O.S., Abram, M.B., Leão Neto, R. Matos, G.M.M., Vidotti, R.M., Ramos, M.A.B., Jesus, J.D.A. de. (Eds.), Carta Geológica do Brasil ao Milionésimo, Sistema de Informações Geográficas. Programa Geologia do Brasil. CPRM, Brasília.

Florisbal, L.M., Heaman, L.M., Janasi, V.A., Bitencourt, M.D., 2014. Tectonic significance of the Florianópolis dyke swarm, Paraná-Etendeka Magmatic Province: a reappraisal based on precise U-Pb dating. Journal of Volcanology and Geothermal Research 289, 140-150.

Fodor, R.V., Sial, A.N., Mukasa, S.B., Mckee, E.H., 1990. Petrology isotope characteristics and $\mathrm{K}-\mathrm{Ar}$ ages of the Maranhão, northern Brazil, Mesozoic basalt province. Contributions to Mineralogy and Petrology 104, 555-567.

Garland, F.E., Hawkesworth, C.J., Mantovani, M.S.M., 1995. Description and petrogenesis of the Parana Rhyolites. Journal of Petrology 36, 1193-1227.

Garland, F.E., Simon, P.T., Hawkesworth, C.J., 1996. Shifts in the source of the Paraná basalts through time. Lithos 37, 223-243.

Gerlach, D.C., Stormer, J.C.J., Mueller, P.A., 1987. Isotopic geochemistry of Fernando de Noronha. Earth and Planetary Science Letters 85, 129-144.

Gibson, S.A., Thompson, R.N., Day, J.A., Humphris, S.E., Dickin, A.P., 2005. Meltgeneration processes associated with the Tristan mantle plume: Constraints on the origin of EM-1. Earth and Planetary Science Letters 237, 744- 767.

Gibson, S.A., Thompson, R.N., Dickin, A.P., Leonardos, O.H., 1995b. High-Ti and low-Ti mafic potassic magmas: Key to plume-lithosphere interactions and continental flood-basalt genesis. Earth and Planetary Science Letters 136, 149-165.

Gibson, S.A., Thompson, R.N., Leonardos, O.H., Dickin, A.P., Mitchell, J.G., 1995a. The Late Cretaceous Impact of the Trindade Mantle Plume: Evidence from Largevolume, Mafic, Potassic Magmatism in SE Brazil. Journal of Petrology 36, 189229.

Gibson, S.A., Thompson, R.N., Leonardos, O.H., Dickin, A.P., Mitchell, J.G., 1999. The limited extent of plume-lithosphere interaction during continental flood basalt genesis: geochemical evidence from Cretaceous magmatism in Southern Brazil. Contributions to Mineralogy and Petrology 137, 147-169.

Gioia, S.M.C.L., Pimentel, M.M., 2000. The Sm-Nd Isotopic Method in the Geochronology Laboratory of the University of Brasília. Anais da Academia Brasileira de Ciências, vol.72 n.2. 
Góes, A.M.O., Feijó, F.J., 1994. Bacia do Parnaíba. Boletim de Geociências da Petrobrás, Rio de Janeiro, 8(1): 57-67.

Góes, A.M.O., Souza, J.M.P., Teixeira, L.B., 1990. Estágio exploratório e perspectivas petrolíferas da Bacia do Parnaíba. Boletim de Geociências da Petrobrás 4 (1), 5564.

Gomes, C.B., Ruberti, E., Comin-Chiaramonti, P., Azzone, R.G., 2011. Alkaline magmatism in the Ponta Grossa Arch, SE Brazil: A review. Journal of South American Earth Sciences 32, 152-168.

Hanyu, T., Tatsumi, Y., Senda, R., Miyazaki, T., Chang, Q., Hirahara, Y., Takahashi, T., Kawabata, H., Suzuki, K., Kimura, J-I., 2011. Geochemical characteristics and origin of the HIMU reservoir: A possible mantle plume source in the lower mantle. Geochemistry, Geophysics, Geosystems 12(2), Q0AC09, doi:10.1029/2010GC003252.

Hartmann, L.A., Areana, K.R., Duarte, S.K., 2012. Geological relationships of basalts, andesites and sand injectites at the base of the Parana Volcanic Province, Torres, Brazil. Journal of Volcanology and Geothermal Research 237-238, 97-111.

Hawkesworth, C.J., Harding, A.J., Kelley, S.P., Mantovani, M.S.M., Peate, D.W., Regelous, M., Rogers, N. W., 1992. Paraná Magmatism and the Opening of the South Atlantic. Special Publication Geological Society of London 68, 221-240.

Hollanda, M.H.B.M., Pimentel, M.M., Jardim de Sá, E.F., 2003. Paleoproterozoic subduction-related metasomatic signatures in the lithospheric mantle beneath NE Brazil: inferences from trace element and $\mathrm{Sr}-\mathrm{Nd}-\mathrm{Pb}$ isotopic compositions of Neoproterozoic high-K igneous rocks. Journal of South American Earth Sciences 15, 885-900.

Hollanda, M.H.B.M., Pimentel, M.M., Oliveira, D.C., de Sá, E.F.J., 2006. Lithosphereasthenosphere interaction and the origin of Cretaceous tholeiitic magmatism in Northeastern Brazil: Sr-Nd-Pb isotopic evidence. Lithos 86, 34-49.

lacumin, P., Piccirillo, E.M., Longinelli, G., 1991. Oxygen isotopic composition of Lower Cretaceous tholeiites and Precambrian basement rocks from the Parana Basin (Brazil): The role of water-rock interaction. Chemical Geology 86, 225-237.

Irvine, T.N. and Baragar, W.R.A., 1971. A Guide to the Chemical Classification of the Common Volcanic Rocks. Canadian Journal of Earth Sciences 8, 523.

Jackson, M.G., Hart, S.R., Koppers, A.A.P., Staudigel, H., Konter, J.G., Blusztajn, J., Kurz, M.D., Russell, J.A., 2007. The return of subducted continental crust in Samoan Lavas. Nature 448, 684-687. 
Janasi, V.A., Montanheiro, T.J., De Freitas, V.A., Reis, P.M., Negri, F.A., Dantas, F.A., 2007. Geology, petrography and geochemistry of the acid volcanism of the Parana Magmatic Province in the Piraju-Ourinhos region, SE Brazil. Revista Brasileira de Geociências 37, 745-759.

Jourdan F., Marzoli, A., Bertrand, H., Cirilli, S., Tanner, L.H., Kontak, D.J., McHone, G., Renne, P.R., Bellieni, G., 2009. 40Ar/39Ar ages of CAMP in North America: Implications for the Triassic-Jurassic boundary and the 40K decay constant bias. Lithos 110, 167-180.

Kirstein, L.A., Peate, D.W., Hawkesworth, C.J., Simon, P.T., Harris, C., Mantovani, M.S.M., 2000. Early Cretaceous basaltic and rhyolitic magmatism in Southern Uruguay associated with the opening of the South Atlantic. Journal of Petrology 41, 1413-1438.

Klein, E.L., Koppe, J.C., Moura, C.A.V., 2002. Geology and geochemistry of the Caxias gold deposit, and geochronology of the gold-hosting Caxias Microtonalite, São Luís Craton, northern Brazil. Journal of South American Earth Science 14, 837849.

Kosin, M., Angelim, L.A.A., Souza, J.D., Guimarães, J.T., Teixeira, L.R., Martins, A.A.M., Bento, R.V., Santos, R.A., Vasconcelos, A.M., Neves, J.P., Wanderley, A.A., Carvalho, L.M., Pereira, L.H.M., Gomes, I.P., 2004. Folha Aracajú SC.24, in: Schobbenhaus, C., Gonçalves, J.H., Santos, J.O.S., Abram, M.B., Leão Neto, R. Matos, G.M.M., Vidotti, R.M., Ramos, M.A.B., Jesus, J.D.A. de. (Eds.), Carta Geológica do Brasil ao Milionésimo, Sistema de Informações Geográficas. Programa Geologia do Brasil. CPRM, Brasília.

Le Bas, M.J., Le Maitre, R.W., Streckeisen, A., Zanettin, B., 1986. A Chemical Classification of Volcanic Rocks Based on the Total Alkali-Silica Diagram. Journal of Petrology, vol. 27, part 3, pp. 745-750.

Lustrino, M., Melluso, L., Brotzu, P., Gomes, C.B., Morbidelli, L., Muzio, R., Ruberti, E., Tassinari, C.C.G., 2005. Petrogenesis of the Early Cretaceous Valle Chico igneous complex (SE Uruguay): Relationships with Parana-Etendeka magmatism. Lithos $82,407-434$.

Mantovani, M.S.M., Hawkesworth, C.J., 1988. Crustal contamination inverted: some preliminary results. Revista Brasileira de Geociências 18, 27-32.

Marques, L.S., Dupre, B., Piccirillo, E.M., 1999. Mantle source compositions of the Paraná Magmatic Province (Southern Brazil): Evidence from the trace element and $\mathrm{Sr}-\mathrm{Nd}-\mathrm{Pb}$ isotope geochemistry. Journal of Geodynamics 28 439-458. 
Marques, L.S., Piccirillo, E.M., Melfi, A.J., Comin-Chiaramonti, P., Bellieni, G., 1989. Distribution of rare earth and other trace elements in basalts of the Parana Basin (Brazil). Geochimica Brasiliensis 3, 33-50.

Martins, L.T., Madeira, J., Youbi, N., Munhá, J., Mata, J., Kerrich, R., 2008. Rift-related magmatism of the Central Atlantic magmatic province in Algarve, Southern Portugal. Lithos 101, 102-124.

Marzoli, A., Jourdan, F., Puffer, J.H., Cuppone, T., Tanner, L.H., Weems, R.E., Bertrand, H., Cirilli, S., Bellieni, G., De Min, A., 2011. Timing and duration of the Central Atlantic magmatic province in the Newark and Culpeper basins, eastern U.S.A. Lithos 122, 175-188.

Marzoli, A., Renne, P.R., Piccirillo, E.M., Ernesto, M., De Min, A., 1999. Extensive 200million-year-old continental flood basalts of the Central Atlantic Magmatic Province. Science 284, 616-618.

McDonough, W.F. and Sun, S.-s., 1995. The composition of the Earth. Chemical Geology 120, 223-253.

McHone, G.J. 2000. Non-plume magmatism and rifting during the opening of the Central Atlantic Ocean. Tectonophysics 316, 287-296.

Merle, R., Marzoli, A., Bertrand, H., Reisberg, L., Verati, C., Zimmermann, C., Chiaradia, M., Bellieni, G., Ernesto, M., 2011. 40Ar/39Ar ages and $\mathrm{Sr}-\mathrm{Nd}-\mathrm{Pb}-\mathrm{Os}$ geochemistry of CAMP tholeiites from Western Maranhão basin (NE Brazil). Lithos 122, 137-151.

Mizusaki, A.M.P., Thomaz-Filho, A., Milani, E.J., de Césero, P., 2002. Mesozoic and Cenozoic igneous activity and its tectonic control in northeastern Brazil. Journal of South American Earth Sciences 15, 183-198.

de Oliveira, D.C., Mohriak, W.U., 2003. Jaibaras trough: an important element in the early tectonic evolution of the Parnaíba interior sag basin, Northern Brazil. Marine and Petroleum Geology 20, 351-383.

Peate, D.W., Hawkesworth C. J., 1996. Lithospheric to Asthenospheric transition in LowTi Flood Basalts from southern Parana, Brazil. Chemical Geology 127, 1-24.

Peate, D.W., Hawkesworth, C.J., Mantovani, M.S.M., 1992. Chemical stratigraphy of the Parana lavas (South America): classification of magma types and their spatial distribution. Bulletin of Volcanology 55 (1-2), 119-139.

Peate, D.W., Hawkesworth, C.J., Mantovani, M.S.M., Rogers, N.W., Simon, P.T., 1999. Petrogenesis and stratigraphy of the High-Ti/Y Urubici magma type in the Paraná 
Flood Basalt Province and implications for the nature of "DUPAL"-type mantle in the South Atlantic region. Journal of Petrology 40, 451-473.

Peate, D.W., Hawkesworth, C.J., Mantovani, M.S.M., Shukowsky, W., 1990. Mantle plumes and flood-basalt stratigraphy in the Parana, South America. Geology 18 (12), 1223-1226.

Peate, D.W., Mantovani, M.S.M., Hawkesworth, C.J., 1988. Chemical stratigraphy of the Parana Continental Flood Basalts: borehole evidence. Revista Brasileira de Geociências 18, 212-221.

Petrini, R., Civetta, L., Piccirillo, E.M., Bellieni, G., Comin-Chiaramonti, P., Marques, L.S., Melfi, A.J., 1987. Mantle heterogeneity and crustal contamination in the genesis of Low-Ti continental flood basalts from the Parana Plateau (Brazil): Sr-Nd isotopes and geochemical evidence. Journal of Petrology 28, 701-726.

Piccirillo, E.M., Bellieni, G., Cavazzini, G., Comin-Chiaramonti, P., Petrini, R., Melfi, A.J., Pinese, J.P.P., Zantedeschi, P., De Min, A., 1990. Lower Cretaceous tholeiitic dyke swarms from the Ponta Grossa Arch (southeast Brazil): Petrology, Sr-Nd isotopes and genetic relationships with the Paraná flood volcanics. Chemical Geology 89, 19-48.

Piccirillo, E.M., Civetta, L., Petrini, R., Longinelli, G., Bellieni, G., Comin-Chiaramonti, P., Marques, L.S., Melfi, A.J. 1989. Regional variations within the Paraná flood basalts (Southern Brazil): evidence for subcontinental mantle heterogeneity and crustal contamination. Chemical Geology 75, 103-122.

Pimentel, M.M., Fuck, R.A., 1992. Neoproterozoic crustal accretion in central Brazil. Geology 20, 375-379.

Pimentel, M.M., Fuck, R.A., Jost, H., Ferreira Filho, C.F., Araújo, S.M., 2000. The basement of the Brasília Fold Belt and the Goiás Magmatic Arc. In: Cordani, U.G., Milani, E.J., Thomaz Filho, A., Campos, D.A. (Eds.), Tectonic Evolution of South America. 31st International Geological Congress, Rio de Janeiro, pp. 151-182.

Rämö, O.T., Heikkilä, P.A., Pulkkinen, A.H., 2016. Geochemistry of Paraná-Etendeka basalts from Misiones, Argentina: Some new insights into the petrogenesis of highTi continental flood basalts. Journal of South American Earth Sciences 67, 25-39.

Renne, P.R., Deckart, K., Ernesto, M., Féraud, G., Piccirillo, E.M., 1996a. Age of the Ponta Grossa dike swarm (Brazil), and implications to Parana flood volcanism. Earth and Planetary Science Letters 144 (1-2), 199-211.

Renne, P.R., Ernesto, M., Pacca, I.G., Coe, R.S., Glen, J.M., Prévot, M., Perrin, M., 1992. The age of Parana flood volcanism, rifting of Gondwanaland, and the JurassicCretaceous boundary. Science 258 (5084), 975-979. 
Renne, P.R., Glen, J.M., Milner, S.C., Duncan, A.R., 1996b. Age of Etendeka flood volcanism and associated intrusions in southwestern Africa. Geology 24 (7), 659662.

Rocha-Junior, E.R.V., Marques, L.S., Babinski, M., Nardy, A.J.R., Figueiredo, A.M.G., Machado, F.B., 2013. Sr-Nd-Pb isotopic constraints on the nature of the mantle sources involved in the genesis of the High-Ti tholeiites from Northern Parana Continental Flood Basalts (Brazil). Journal of South American Earth Sciences 46, 9-25.

Rocha-Junior, E.R.V., Puchtel, I.S., Marques, L.S., Walker, R.J., Machado, F.B., Nardy, A.J.R., Babinski, M., Figueiredo, A.M.G., 2012. Re-Os isotope and highly siderophile element systematics of the Paraná Continental Flood Basalts (Brazil). Earth and Planetary Science Letters 337-338, 164-173.

Rock N.M.S., (Eds.) 1991. Lamprophyres. London, Blackie \& Son, 284 p.

Sadowski G. R. and Campanha G. A. C. 2004. Grandes falhas no Brasil continental, in: Montesso Neto, V., Bartorelli A., Carneiro C.D.R., Brito-Neves B.B. (Eds.), Geologia do Continente Sul Americano - evolução da obra de Fernando Flávio Marques de Almeida. Editora Becca, p. 407-421.

Santos Barreto, C.J., De Lima E.F., Scherer, C.M., May Rossetti L.de M., 2014. Lithofacies analysis of basic lava flows of the Parana Igneous Province in the South Hinge of Torres Syncline, Southern Brazil. Journal of Volcanology and Geothermal Research 285, 81-99.

Schenato, F., Formoso, M.L.L., Dudoignon, P., Meunier, A., Proust, D., Mas, A., 2003. Alteration processes of a thick basaltic lava flow of the Paraná Basin (Brazil): petrographic and mineralogical studies. Journal of South American Earth Science $16,423-444$.

Sheth, H., 2007. Large Igneous Provinces (LIPs): definition, recommended terminology, and a hierarchical classification. Earth Science Reviews 85, 117-124.

Sial, A.N., Dardenne, M.A., Misi, A., Pedreira, A., Ferreira, V.P., Silva Filho, M., Uhlein, A., Pedrosa, A.C., Santos, R.V., Egydio-Silva, M., Babinski, M., Alvarenga, J.C., Fairchild, T.R., Pimentel, M.M., 2010. The São Francisco Paleocontinent. In: Gaucher, C., Sial, A.N., Frimmel, H., Halverson, G.P. (Eds.), NeoproterozoicCambrian Tectonics, Global Change and Evolution: A focus on Southwestern Gondwana, 16. Elsevier, Amsterdam, pp. 31-69.

Simon, P.T., Kirstein, L.A., Hawkesworth, C.J., Peate, D.W., Hallinan, S., Mantovani, M.S.M., 1999b. Petrogenesis of an $800 \mathrm{~m}$ lava sequence in Eastern Uruguay: insights into magma chamber processes beneath the Paraná Flood Basalt Province. Journal of Geodynamics 28, 471-487. 
Simon, P.T., Peate, D.W., Hawkesworth, C.J., Mantovani, M.S.M., 1999a. Chemical stratigraphy of the Paraná basalt succession in Western Uruguay: further evidence for the diachronous nature of the Paraná magma types. Journal of Geodynamics 28, 459-469.

Sun, S.-s. and McDonough, W.F., 1989. Chemical and isotopic systematics of ocean basalts: implications for mantle composition and processes. Geological Society, London, Special Publication No. 42, pp. 313-345.

Thiede, D.S. and Vasconcelos, P.M., 2010. Parana flood basalts: rapid extrusion hypothesis confirmed by new 40Ar/39Ar results. Geology 38 (8), 747-750.

Thomaz Filho, A., Mizusaki, A.M.P., Antonioli, L., 2008. Magmatism and petroleum exploration in the Brazilian Paleozoic basins. Marine and Petroleum Geology 25, 143-151.

Thompson, R.N., Gibson, S.A., Mitchell, J.G., Dickin, A.P., Leonardos, O.H., Brod, J.A., Greenwood, J.C., 1998. Migrating Cretaceous-Eocene Magmatism in the Serra do Mar Alkaline Province, SE Brazil: Melts from the Deflected Trindade Mantle Plume?. Journal of Petrology 39, 1493-1526.

Van Schmus, W.R., Brito Neves, B.B., Hackspacher, P., Babinski, M., 1995. U/Pb and $\mathrm{Sm} / \mathrm{Nd}$ geochronologic studies of eastern Borborema Province, northeastern Brazil: initial conclusions. Journal of South American Earth Science 8, 267-288.

Vasconcelos, A.M., Veiga Júnior, J., Colares, J.Q.S., Ribeiro, J.A.P., Gomes, I.P., Medeiros, M.F Forgiarini, I.I., 2004a. Folha SA.23-São Luís, in: Schobbenhaus, C., Gonçalves, J.H., Santos, J.O.S., Abram, M.B., Leão Neto, R., Matos, G.M.M., Vidotti, R.M., Ramos, M.A.B., Jesus, J.D.A de. (Eds.), Carta Geológica do Brasil ao Milionésimo, Sistema de Informações Geográficas. Programa Geologia do Brasil. CPRM, Brasília.

Vasconcelos, A.M., Veiga Júnior, J., Colares, J.Q.S., Ribeiro, J.A.P., Gomes, I.P., Medeiros, M.F Forgiarini, I.I., 2004b. Folha SA.24-Fortaleza, in: Schobbenhaus, C., Gonçalves, J.H., Santos, J.O.S., Abram, M.B., Leão Neto, R., Matos, G.M.M., Vidotti, R.M., Ramos, M.A.B., Jesus, J.D.A de. (Eds.), Carta Geológica do Brasil ao Milionésimo, Sistema de Informações Geográficas. Programa Geologia do Brasil. CPRM, Brasília.

Vasconcelos, A.M., Veiga Júnior, J., Colares, J.Q.S., Ribeiro, J.A.P., Gomes, I.P., Medeiros, M.F Forgiarini, I.I., 2004c. Folha Teresina SB.23, in: Schobbenhaus, C., Gonçalves, J.H., Santos, J.O.S., Abram, M.B., Leão Neto, R., Matos, G.M.M., Vidotti, R.M., Ramos, M.A.B., Jesus, J.D.A de. (Eds.), Carta Geológica do Brasil ao Milionésimo, Sistema de Informações Geográficas. Programa Geologia do Brasil. CPRM, Brasília. 
Vasconcelos, A.M., Kosin, M., Souza, J.D. de, Valente, C.R., Neves, J.P., Heineck, C.A., Lacerda Filho, J.V., Teixeira, L.R., Borges, V.P., Bento, R.V., Guimarães, J.T., Neves, J.P., Oliveira, I.W.B., Gomes, I.P., Malouf, R.F., Carvalho, L.M. de, Abreu Filho, W., 2004d. Folha SC.23 - Rio São Francisco, in: Schobbenhaus, C., Gonçalves, J.H., Santos, J.O.S., Abram, M.B., Leão Neto, R., Matos, G.M.M., Vidotti, R.M., Ramos, M.A.B., Jesus, J.D.A.de. (Eds.), Carta Geológica do Brasil ao Milionésimo, Sistema de Informações Geográficas. Programa Geologia do Brasil, CPRM, Brasília.

Vaz, P.T., Rezende, N.G.A.M., Wanderley Filho, J.R., Travasso, W.A.S., 2007. Bacia do Parnaíba. Boletim de Geociências da Petrobrás, Rio de Janeiro, v. 15, n. 2, p. 253263.

White, R., McKenzie, D., 1989. Magmatism at rift zones: the generation of volcanic continental margins and flood basalts. Journal of Geophysical Research 94, 76857729 .

Workman, R.K. and Hart, S.R., 2005. Major and trace element composition of the depleted MORB mantle (DMM). Earth and Planetary Science Letters 231, 53- 72.

Zalán P.V., 2004. A Evolução Fanerozóica das Bacias Sedimentares Brasileiras, in: Montesso Neto, V., Bartorelli A., Carneiro C.D.R., Brito-Neves B.B. (Eds.), Geologia do Continente Sul Americano - evolução da obra de Fernando Flávio Marques de Almeida. Editora Becca, p.595-612.

Zindler, A., Hart, S., 1986. Chemical geodynamics. Annual Review of Earth and Planetary Sciences 14, 493- 571. 


\section{CONCLUSÃO}

A pesquisa proporcionou geração de dados relevantes às rochas magmáticas da Bacia do Parnaíba que foram detalhados no capítulo anterior. De forma geral, os dados petrográficos, geoquímicos e isotópicos permitiram o levantamento de algumas conclusões que seguem:

1- As rochas magmáticas são expostas em grandes áreas das partes central e NE da Bacia do Parnaíba, sendo responsável por uma parte importante da subsidência e incremento térmico da bacia.

2- Acreditava-se que as diferenças de idade fossem a única fonte confiável de informações sobre a diferenciação entre os dois eventos, mas as evidências geoquímicas apresentadas neste trabalham se mostraram úteis para entender e caracterizar diques, soleiras e derrames de basalto. Os elementos traço (por exemplo, Fig. 12) podem ser um indicador confiável para a distinção de cada evento magmático da bacia.

3- A Formação Mosquito está inegavelmente relacionada ao magmatismo CAMP.

4- Os basaltos da Formação Sardinha ainda necessitam de maior investigação, visando determinar sua variação composicional e correlação com outros eventos CFB na plataforma sul-americana. Sua relação com os eventos PEMP e EQA é possível, porém exige estudos adicionais.

5- O componente alcalino dos basaltos da Formação Sardinha pode representar um evento magmático completamente diferente, de composição, idade ou gênese distintas das outras rochas da Formação Sardinha. Pode ainda representar um componente 
alcalino do magmatismo Sardinha originado por uma pluma mantélica ou por graus mais baixos de fusão do manto.

6- As fontes mantélicas do magmatismo basáltico na bacia estão em estreita relação com membros finais enriquecidos do manto, abaixo da bacia. Acredita-se que a Formação de Mosquito seja originada do manto continental sub-litosférico (Merle et al., 2011) ou de componentes do manto EMI ou EMII. A composição de HIMU do manto poderia também ser um contribuinte para a gênese dos basaltos de alto-Ti.

7- A origem da Formação Sardinha é mais controversa. Múltiplos tipos de magmas, no ponto de vista geoquímico e isotópico, requerem uma gênese mais complexa (como o magmatismo PEMP no sudoeste do Brasil). É evidente que, para a sua formação, uma fonte de manto multifacetada é essencial. A origem mais provável está relacionada com componentes HIMU, EMI e EMII (como mostrado na Fig.15). Além disso, as fusões derivadas de plumas mantélicas podem ser responsáveis por alguns tipos de magma, como os álcalibasaltos, semelhantes ao arquipélago próximo de Fernando de Noronha, e podem ser, até certo ponto, correlato com a origem deste magmatismo.

8- A Bacia do Parnaíba representa uma área importante para estudos tectônicos, geofísicos, petrológicos e sedimentológicos. Conhecimentos adicionais resultantes de novos estudos serão cruciais para caracterizar não apenas o magmatismo, mas também sua relação com os mecanismos de formação e evolução da bacia, bem como a origem de hidrocarbonetos associados a eventos magmáticos. 


\section{ANEXOS}

\subsection{Química mineral em olivina}

\begin{tabular}{|c|c|c|c|c|c|c|c|}
\hline $\begin{array}{l}\text { Amostra } \\
\text { Formação } \\
\text { Grupo }\end{array}$ & $\begin{array}{l}\text { DCO-36 } \\
\text { Sardinha } \\
\text { Alcalino }\end{array}$ & $\begin{array}{l}\text { DCO-40 ol C } \\
\text { Sardinha } \\
\text { Alcalino }\end{array}$ & $\begin{array}{l}\text { DCO-40 ol B } \\
\text { Sardinha } \\
\text { Alcalino }\end{array}$ & $\begin{array}{l}\text { DCO-52 } \\
\text { Sardinha } \\
\text { Alcalino }\end{array}$ & $\begin{array}{l}\text { DCO-53 } \\
\text { Sardinha } \\
\text { Alcalino }\end{array}$ & $\begin{array}{l}\text { DCO-49 } \\
\text { Sardinha } \\
\text { Baixo-Ti } \\
\text { ol }\end{array}$ & $\begin{array}{l}\text { DCO-54 } \\
\text { Sardinha } \\
\text { Baixo-Ti } \\
\text { ol } \\
\end{array}$ \\
\hline $\mathrm{SiO}_{2}(\%)$ & 36.04 & 39.26 & 36.29 & 39.71 & 36.02 & 35.40 & 36.18 \\
\hline $\mathrm{TiO}_{2}$ & 0.00 & 0.06 & 0.00 & 0.00 & 0.16 & 0.00 & 0.00 \\
\hline $\mathrm{Al}_{2} \mathrm{O}_{3}$ & 0.02 & 0.06 & 0.02 & 0.00 & 0.03 & 0.00 & 0.03 \\
\hline $\mathrm{FeO}$ & 30.70 & 13.50 & 30.31 & 13.88 & 34.93 & 35.11 & 34.37 \\
\hline MnO & 0.40 & 0.26 & 0.47 & 0.05 & 0.44 & 0.49 & 0.35 \\
\hline MgO & 32.14 & 46.64 & 31.78 & 45.95 & 28.07 & 28.41 & 28.60 \\
\hline $\mathrm{CaO}$ & 0.41 & 0.29 & 0.37 & 0.20 & 0.48 & 0.19 & 0.26 \\
\hline $\mathrm{Cr}_{2} \mathrm{O}_{3}$ & 0.05 & 0.11 & 0.00 & 0.04 & 0.00 & 0.00 & 0.03 \\
\hline $\mathrm{NiO}$ & 0.09 & 0.30 & 0.15 & 0.25 & 0.07 & 0.05 & 0.13 \\
\hline Total & 99.87 & 100.49 & 99.38 & 100.06 & 100.20 & 99.64 & 99.95 \\
\hline \multicolumn{8}{|c|}{ Normalização baseada em 4 oxigênios } \\
\hline Si (átomos \%) & 0.978 & 0.974 & 0.990 & 0.991 & 0.999 & 0.985 & 1.002 \\
\hline $\mathrm{Ti}$ & 0.000 & 0.001 & 0.000 & 0.000 & 0.003 & 0.000 & 0.000 \\
\hline Al & 0.000 & 0.001 & 0.000 & 0.000 & 0.000 & 0.000 & 0.000 \\
\hline $\mathrm{Fe}^{2+}$ & 0.697 & 0.280 & 0.692 & 0.289 & 0.810 & 0.817 & 0.796 \\
\hline Mn & 0.009 & 0.005 & 0.011 & 0.001 & 0.010 & 0.012 & 0.008 \\
\hline Mg & 1.301 & 1.724 & 1.293 & 1.708 & 1.161 & 1.179 & 1.181 \\
\hline $\mathrm{Ca}$ & 0.012 & 0.008 & 0.011 & 0.005 & 0.014 & 0.006 & 0.008 \\
\hline $\mathrm{Cr}$ & 0.001 & 0.001 & 0.000 & 0.000 & 0.000 & 0.000 & 0.000 \\
\hline $\mathrm{Ni}$ & 0.002 & 0.006 & 0.003 & 0.005 & 0.002 & 0.001 & 0.003 \\
\hline Total & 3.000 & 3.000 & 3.000 & 3.000 & 3.000 & 3.000 & 3.000 \\
\hline Fo (\%) & 69.820 & 77.551 & 51.189 & 76.802 & 44.561 & 50.740 & 45.422 \\
\hline
\end{tabular}

Nota: DCO-40 ol C e DCO-40 ol B representam as análises de centro e borda em um mesmo cristal de olivina.

Baixo-Ti ol = Grupo de baixo-Ti, olivina/hiperstênio normativo 


\subsection{Química mineral em clinopiroxênio (augita)}

\begin{tabular}{|c|c|c|c|c|c|c|c|}
\hline $\begin{array}{l}\text { Amostra } \\
\text { Formação } \\
\text { Grupo }\end{array}$ & $\begin{array}{c}\text { BP-30 } \\
\text { Mosquito } \\
\text { Alto-Ti }\end{array}$ & $\begin{array}{c}\text { BP-117 } \\
\text { Mosquito } \\
\text { Alto-Ti }\end{array}$ & $\begin{array}{c}\text { BP-35 } \\
\text { Mosquito } \\
\text { Baixo-Ti }\end{array}$ & $\begin{array}{c}\text { BP-54 } \\
\text { Mosquito } \\
\text { Baixo-Ti }\end{array}$ & $\begin{array}{c}\text { DCO-52 } \\
\text { Sardinha } \\
\text { Alcalino }\end{array}$ & $\begin{array}{c}\text { DCO-40 } \\
\text { Sardinha } \\
\text { Alcalino }\end{array}$ & $\begin{array}{c}\text { DCO-56 } \\
\text { Sardinha } \\
\text { Alto-Ti }\end{array}$ \\
\hline $\mathrm{SiO}_{2}(\%)$ & 51.92 & 49.35 & 53.46 & 52.79 & 49.74 & 51.10 & 51.36 \\
\hline $\mathrm{TiO}_{2}$ & 0.36 & 1.35 & 0.13 & 0.45 & 1.31 & 1.05 & 0.79 \\
\hline $\mathrm{Al}_{2} \mathrm{O}_{3}$ & 2.00 & 3.43 & 1.52 & 1.61 & 3.90 & 3.49 & 1.76 \\
\hline FeO & 10.51 & 9.87 & 8.14 & 10.10 & 6.85 & 5.20 & 14.79 \\
\hline MnO & 0.39 & 0.15 & 0.24 & 0.17 & 0.08 & 0.30 & 0.31 \\
\hline MgO & 15.75 & 15.76 & 17.77 & 16.72 & 15.23 & 16.70 & 14.51 \\
\hline $\mathrm{CaO}$ & 18.45 & 19.07 & 17.92 & 17.28 & 21.86 & 21.15 & 16.00 \\
\hline $\mathrm{Na}_{2} \mathrm{O}$ & 0.26 & 0.29 & 0.14 & 0.77 & 0.53 & 0.35 & 0.21 \\
\hline $\mathrm{Cr}_{2} \mathrm{O}_{3}$ & 0.01 & 0.42 & 0.41 & 0.00 & 0.17 & 0.69 & 0.03 \\
\hline $\mathrm{V}_{2} \mathrm{O}_{3}$ & 0.04 & 0.09 & 0.03 & 0.10 & 0.04 & 0.04 & 0.00 \\
\hline $\mathrm{NiO}$ & 0.08 & 0.02 & 0.01 & 0.00 & 0.02 & 0.06 & 0.04 \\
\hline Total & 99.77 & 99.80 & 99.77 & 99.98 & 99.74 & 100.13 & 99.81 \\
\hline \multicolumn{8}{|c|}{ Normalização baseada em 6 oxigênios } \\
\hline Si (átomos \%) & 1.931 & 1.833 & 1.968 & 1.944 & 1.835 & 1.867 & 1.940 \\
\hline Al & 0.088 & 0.150 & 0.066 & 0.070 & 0.169 & 0.150 & 0.078 \\
\hline Mg & 0.873 & 0.873 & 0.975 & 0.918 & 0.838 & 0.910 & 0.817 \\
\hline $\mathrm{Ti}$ & 0.010 & 0.038 & 0.004 & 0.012 & 0.036 & 0.029 & 0.022 \\
\hline $\mathrm{Cr}$ & 0.000 & 0.012 & 0.012 & 0.000 & 0.005 & 0.020 & 0.001 \\
\hline $\mathrm{Fe}^{3+}$ & 0.047 & 0.097 & 0.000 & 0.070 & 0.120 & 0.061 & 0.012 \\
\hline $\mathrm{Fe}^{2+}$ & 0.280 & 0.193 & 0.251 & 0.242 & 0.091 & 0.098 & 0.455 \\
\hline $\mathrm{Ni}$ & 0.000 & 0.000 & 0.000 & 0.000 & 0.000 & 0.000 & 0.000 \\
\hline$M n$ & 0.012 & 0.005 & 0.007 & 0.005 & 0.002 & 0.009 & 0.010 \\
\hline $\mathrm{Ca}$ & 0.735 & 0.759 & 0.707 & 0.682 & 0.864 & 0.828 & 0.647 \\
\hline $\mathrm{Na}$ & 0.019 & 0.021 & 0.010 & 0.055 & 0.038 & 0.025 & 0.016 \\
\hline Total & 4.000 & 3.980 & 4.000 & 4.000 & 4.000 & 4.000 & 4.000 \\
\hline En (\%) & 45.12 & 45.03 & 50.46 & 48.04 & 43.79 & 47.98 & 42.29 \\
\hline
\end{tabular}




\subsection{Continuação}

\begin{tabular}{|c|c|c|c|}
\hline $\begin{array}{l}\text { Amostra } \\
\text { Formação } \\
\text { Grupo }\end{array}$ & $\begin{array}{l}\text { DCO-39 } \\
\text { Sardinha } \\
\text { Alto-Ti }\end{array}$ & $\begin{array}{c}\text { DCO-49 } \\
\text { Sardinha } \\
\text { Baixo-Ti ol }\end{array}$ & $\begin{array}{c}\text { DCO-54 } \\
\text { Sardinha } \\
\text { Baixo-Ti ol }\end{array}$ \\
\hline $\mathrm{SiO}_{2}(\%)$ & 50.58 & 51.66 & 51.92 \\
\hline $\mathrm{TiO}_{2}$ & 1.09 & 0.70 & 0.85 \\
\hline $\mathrm{Al}_{2} \mathrm{O}_{3}$ & 2.56 & 2.14 & 1.90 \\
\hline $\mathrm{FeO}$ & 15.45 & 9.82 & 10.02 \\
\hline MnO & 0.39 & 0.29 & 0.32 \\
\hline MgO & 13.98 & 16.08 & 16.49 \\
\hline $\mathrm{CaO}$ & 15.35 & 17.82 & 17.96 \\
\hline $\mathrm{Na}_{2} \mathrm{O}$ & 0.28 & 0.41 & 0.42 \\
\hline $\mathrm{Cr}_{2} \mathrm{O}_{3}$ & 0.00 & 0.49 & 0.13 \\
\hline $\mathrm{V}_{2} \mathrm{O}_{3}$ & 0.12 & 0.13 & 0.11 \\
\hline $\mathrm{NiO}$ & 0.07 & 0.05 & 0.03 \\
\hline Total & 99.87 & 99.60 & 100.16 \\
\hline \multicolumn{4}{|c|}{ Normalização baseada em 6 oxigênios } \\
\hline Si (átomos \%) & 1.915 & 1.921 & 1.917 \\
\hline Al & 0.114 & 0.094 & 0.083 \\
\hline Mg & 0.789 & 0.891 & 0.908 \\
\hline $\mathrm{Ti}$ & 0.031 & 0.020 & 0.024 \\
\hline $\mathrm{Cr}$ & 0.000 & 0.014 & 0.004 \\
\hline $\mathrm{Fe}^{3+}$ & 0.010 & 0.036 & 0.058 \\
\hline $\mathrm{Fe}^{2+}$ & 0.479 & 0.269 & 0.251 \\
\hline $\mathrm{Ni}$ & 0.000 & 0.000 & 0.000 \\
\hline Mn & 0.013 & 0.009 & 0.010 \\
\hline $\mathrm{Ca}$ & 0.623 & 0.710 & 0.710 \\
\hline $\mathrm{Na}$ & 0.020 & 0.030 & 0.030 \\
\hline Total & 3.990 & 3.990 & 4.000 \\
\hline En (\%) & 41.50 & 46.75 & 47.10 \\
\hline
\end{tabular}




\subsection{Química mineral em clinopiroxênio (pigeonite)}

\begin{tabular}{|c|c|c|c|c|c|c|}
\hline $\begin{array}{l}\text { Amostra } \\
\text { Formação } \\
\text { Grupo }\end{array}$ & $\begin{array}{c}\text { BP-128 } \\
\text { Mosquito } \\
\text { Alto-Ti }\end{array}$ & $\begin{array}{c}\text { BP-35 } \\
\text { Mosquito } \\
\text { Baixo-Ti }\end{array}$ & $\begin{array}{c}\text { BP-56A } \\
\text { Mosquito } \\
\text { Baixo-Ti }\end{array}$ & $\begin{array}{c}\text { DCO-55 } \\
\text { Sardinha } \\
\text { Alto-Ti }\end{array}$ & $\begin{array}{c}\text { DCO-39 } \\
\text { Sardinha } \\
\text { Alto-Ti }\end{array}$ & $\begin{array}{c}\text { DCO-49 } \\
\text { Sardinha } \\
\text { Baixo-Ti ol }\end{array}$ \\
\hline $\mathrm{SiO}_{2}(\%)$ & 49.84 & 54.53 & 54.80 & 51.10 & 51.66 & 52.38 \\
\hline $\mathrm{TiO}_{2}$ & 0.64 & 0.27 & 0.09 & 0.45 & 0.43 & 0.84 \\
\hline $\mathrm{Al}_{2} \mathrm{O}_{3}$ & 0.56 & 0.77 & 0.69 & 0.78 & 0.77 & 0.52 \\
\hline $\mathrm{FeO}$ & 28.65 & 14.63 & 14.23 & 22.76 & 23.94 & 20.75 \\
\hline Mno & 0.64 & 0.39 & 0.30 & 0.73 & 0.57 & 0.29 \\
\hline MgO & 14.95 & 25.06 & 25.86 & 18.16 & 17.37 & 20.61 \\
\hline $\mathrm{CaO}$ & 4.23 & 4.11 & 3.91 & 5.47 & 5.58 & 3.79 \\
\hline $\mathrm{Na}_{2} \mathrm{O}$ & 0.03 & 0.04 & 0.05 & 0.06 & 0.09 & 0.09 \\
\hline $\mathrm{Cr}_{2} \mathrm{O}_{3}$ & 0.11 & 0.07 & 0.09 & 0.01 & 0.00 & 0.05 \\
\hline $\mathrm{V}_{2} \mathrm{O}_{3}$ & 0.00 & 0.02 & 0.05 & 0.01 & 0.00 & 0.00 \\
\hline $\mathrm{NiO}$ & 0.10 & 0.05 & 0.01 & 0.04 & 0.04 & 0.02 \\
\hline Total & 99.74 & 99.94 & 100.09 & 99.57 & 100.44 & 99.34 \\
\hline \multicolumn{7}{|c|}{ Normalização baseada em 6 oxigênios } \\
\hline Si (átomos \%) & 1.945 & 1.980 & 1.978 & 1.945 & 1.959 & 1.972 \\
\hline Al & 0.026 & 0.033 & 0.030 & 0.035 & 0.034 & 0.023 \\
\hline Mg & 0.869 & 1.357 & 1.392 & 1.030 & 0.982 & 1.157 \\
\hline $\mathrm{Ti}$ & 0.019 & 0.007 & 0.002 & 0.013 & 0.012 & 0.024 \\
\hline $\mathrm{Cr}$ & 0.004 & 0.002 & 0.003 & 0.000 & 0.000 & 0.001 \\
\hline $\mathrm{Fe}^{3+}$ & 0.016 & 0.000 & 0.009 & 0.033 & 0.023 & 0.000 \\
\hline $\mathrm{Fe}^{2+}$ & 0.889 & 0.444 & 0.420 & 0.671 & 0.729 & 0.653 \\
\hline $\mathbf{N i}$ & 0.000 & 0.000 & 0.000 & 0.000 & 0.000 & 0.000 \\
\hline$M n$ & 0.021 & 0.012 & 0.009 & 0.023 & 0.018 & 0.009 \\
\hline $\mathrm{Ca}$ & 0.177 & 0.160 & 0.151 & 0.223 & 0.227 & 0.153 \\
\hline $\mathrm{Na}$ & 0.002 & 0.003 & 0.004 & 0.004 & 0.007 & 0.007 \\
\hline Total & 3.970 & 4.000 & 4.000 & 3.980 & 3.990 & 4.000 \\
\hline En (\%) & 43.88 & 69.19 & 70.57 & 52.10 & 49.90 & 58.92 \\
\hline
\end{tabular}




\subsection{Química mineral em plagioclásio}

\begin{tabular}{|c|c|c|c|c|c|c|c|}
\hline $\begin{array}{l}\text { Amostra } \\
\text { Formação } \\
\text { Grupo }\end{array}$ & $\begin{array}{c}\text { BP-30 } \\
\text { Mosquito } \\
\text { Alto-Ti }\end{array}$ & $\begin{array}{c}\text { BP-30 } \\
\text { Mosquito } \\
\text { Alto-Ti }\end{array}$ & $\begin{array}{c}\text { BP-35 } \\
\text { Mosquito } \\
\text { Baixo-Ti }\end{array}$ & $\begin{array}{c}\text { BP-54 } \\
\text { Mosquito } \\
\text { Baixo-Ti }\end{array}$ & $\begin{array}{c}\text { DCO-36 } \\
\text { Sardinha } \\
\text { Alcalino }\end{array}$ & $\begin{array}{c}\text { DCO-40 } \\
\text { Sardinha } \\
\text { Alcalino }\end{array}$ & $\begin{array}{c}\text { DCO-39 } \\
\text { Sardinha } \\
\text { Alto-Ti }\end{array}$ \\
\hline $\mathrm{SiO}_{2}(\%)$ & 50.85 & 49.29 & 53.79 & 52.03 & 52.50 & 57.23 & 55.11 \\
\hline $\mathrm{Al}_{2} \mathrm{O}_{3}$ & 30.19 & 31.62 & 28.17 & 29.50 & 28.98 & 26.41 & 27.38 \\
\hline $\mathrm{TiO}_{2}$ & 0.18 & 0.06 & 0.21 & 0.02 & 0.15 & 0.15 & 0.33 \\
\hline $\mathrm{FeO}$ & 1.17 & 0.76 & 0.73 & 0.75 & 0.42 & 0.40 & 0.66 \\
\hline $\mathrm{CaO}$ & 13.60 & 14.84 & 11.45 & 13.17 & 12.29 & 8.39 & 10.68 \\
\hline $\mathrm{Na}_{2} \mathrm{O}$ & 3.45 & 2.83 & 5.05 & 4.04 & 4.74 & 6.48 & 5.15 \\
\hline $\mathrm{K}_{2} \mathrm{O}$ & 0.09 & 0.05 & 0.21 & 0.22 & 0.26 & 0.45 & 0.46 \\
\hline $\mathrm{BaO}$ & 0.03 & 0.00 & 0.04 & 0.08 & 0.02 & 0.16 & 0.17 \\
\hline Total & 99.55 & 99.46 & 99.66 & 99.81 & 99.36 & 99.66 & 99.94 \\
\hline \multicolumn{8}{|c|}{ Normalização baseada em 8 oxigênios } \\
\hline Si (átomos \%) & 2.329 & 2.263 & 2.448 & 2.373 & 2.400 & 2.578 & 2.495 \\
\hline Al & 1.630 & 1.711 & 1.511 & 1.586 & 1.561 & 1.402 & 1.461 \\
\hline $\mathrm{Fe}^{2+}$ & 0.045 & 0.029 & 0.028 & 0.029 & 0.016 & 0.015 & 0.025 \\
\hline $\mathrm{Ca}$ & 0.667 & 0.730 & 0.558 & 0.643 & 0.602 & 0.405 & 0.518 \\
\hline $\mathrm{Na}$ & 0.306 & 0.252 & 0.445 & 0.357 & 0.420 & 0.566 & 0.452 \\
\hline K & 0.005 & 0.003 & 0.012 & 0.013 & 0.015 & 0.026 & 0.027 \\
\hline Total & 4.982 & 4.987 & 5.003 & 5.001 & 5.014 & 4.991 & 4.978 \\
\hline An (\%) & 68.20 & 74.13 & 54.96 & 63.48 & 58.05 & 40.61 & 51.97 \\
\hline
\end{tabular}




\subsection{Localização das amostras}

\begin{tabular}{|c|c|c|c|c|c|}
\hline Amostra & Latitude & Longitude & Formação & Grupo & Rocha \\
\hline BP02 & 9301761 & 238192 & Mosquito & baixo-Ti & Basalto maciço/topo amigdaloidal \\
\hline BP19 & 9244993 & 333815 & Mosquito & alto-Ti & Basalto maciço \\
\hline BP30 & 9225562 & 352147 & Mosquito & alto-Ti & Basalto maciço \\
\hline BP35 & 9201876 & 358493 & Mosquito & baixo-Ti & Basalto maciço/topo amigdaloidal \\
\hline BP39 & 9254788 & 373122 & Mosquito & baixo-Ti & Basalto maciço \\
\hline BP54 & 9310849 & 340703 & Mosquito & baixo-Ti & Basalto maciço/topo amigdaloidal \\
\hline BP56 & 9356878 & 373392 & Mosquito & baixo-Ti & Basalto maciço/topo amigdaloidal \\
\hline BP61 & 9304759 & 249703 & Mosquito & baixo- $\mathrm{Ti}$ & Basalto amigdaloidal \\
\hline BP117 & 9327110 & 236342 & Mosquito & alto-Ti & Diabásio fino \\
\hline BP119 & 9291842 & 236308 & Mosquito & baixo- $\mathrm{Ti}$ & Basalto vesicular/amigdaloidal \\
\hline BP121 & 9219902 & 230279 & Mosquito & baixo-Ti & Basalto maciço fino \\
\hline BP128 & 9177851 & 170061 & Mosquito & alto-Ti & Diabásio \\
\hline BP129 & 9178800 & 830973 & Mosquito & baixo-Ti & Basalto maciço/topo amigdaloidal \\
\hline BP156 & 8933767 & 319500 & Mosquito & alto- $\mathrm{Ti}$ & $\begin{array}{l}\text { Basalto maciço, topo } \\
\text { amigdaloidal }\end{array}$ \\
\hline DCO-36 & 9558671 & 226226 & Sardinha & alcalino & Olivina diabásio/micro gabro \\
\hline DCO-37 & 9550805 & 171025 & Sardinha & alto-Ti & Basalto maciço \\
\hline DCO-39 & 9564438 & 812936 & Sardinha & alto- $\mathrm{Ti}$ & Basalto maciço \\
\hline DCO-40 & 9583429 & 800727 & Sardinha & alcalino & Olivina basalto \\
\hline DCO-41 & 9593643 & 763219 & Sardinha & baixo-Ti & Basalto maciço \\
\hline DCO-43 & 9590761 & 773258 & Sardinha & alto-Ti & Basalto maciço/diabásio \\
\hline DCO-45 & 9567992 & 807326 & Sardinha & baixo-Ti & Basalto maciço \\
\hline DCO-46 & 9509454 & 225240 & Sardinha & alto-Ti & Basalto maciço/diabásio \\
\hline DCO-47 & 9512795 & 225319 & Sardinha & baixo-Ti & Olivina diabásio \\
\hline DCO-48 & 9513682 & 182752 & Sardinha & alto-Ti & Basalto maciço/diabásio \\
\hline DCO-49 & 9461066 & 764441 & Sardinha & baixo-Ti & Olivina diabásio \\
\hline DCO-50 & 9425229 & 795427 & Sardinha & baixo-Ti & Olivina diabásio \\
\hline DCO-51 & 9426158 & 798113 & Sardinha & alto-Ti & Diabásio \\
\hline DCO-52 & 9387822 & 761125 & Sardinha & alcalino & Olivina basalto \\
\hline DCO-53 & 9373985 & 766883 & Sardinha & alcalino & Olivina diabásio/micro gabro \\
\hline DCO-54 & 9326294 & 748671 & Sardinha & baixo-Ti & Olivina basalto/diabásio \\
\hline DCO-55 & 9324013 & 751840 & Sardinha & alto-Ti & Diabásio \\
\hline DCO-56 & 9309049 & 740361 & Sardinha & alto-Ti & Diabásio \\
\hline DCO-57 & 9308601 & 738680 & Sardinha & alto-Ti & Diabásio \\
\hline DCO-58 & 9252958 & 818249 & Sardinha & alto-Ti & Diabásio \\
\hline
\end{tabular}

